\author{
UNIVERSIDADE DE SÃO PAULO \\ FACULDADE DE FILOSOFIA, LETRAS E CIÊNCIAS HUMANAS \\ DEPARTAMENTO DE LETRAS MODERNAS \\ PROGRAMA DE PÓS-GRADUAÇÃO EM LÍNGUA INGLESA E LITERATURAS \\ INGLESA E NORTE-AMERICANA
}

\title{
ENSINO REFLEXIVO E DISCURSO NEOLIBERAL: ANÁLISE DE UMA EXPERIÊNCIA (revisada)
}




\author{
UNIVERSIDADE DE SÃO PAULO \\ FACULDADE DE FILOSOFIA, LETRAS E CIÊNCIAS HUMANAS \\ DEPARTAMENTO DE LETRAS MODERNAS \\ PROGRAMA DE PÓS-GRADUAÇÃO EM LÍNGUA INGLESA E LITERATURAS \\ INGLESA E NORTE-AMERICANA
}

\title{
ENSINO REFLEXIVO E DISCURSO NEOLIBERAL: \\ ANÁLISE DE UMA EXPERIÊNCIA
}

\author{
CHRISTIANE ELANY BRITTO DE ARAÚJO
}

DISSERTAÇ̃̃O APRESENTADA À UNIVERSIDADE DE SÃO PAULO, COMO EXIGÊNCIA PARCIAL PARA OBTENÇÃO DO TÍTULO DE MESTRE EM LÍNGUA E LITERATURAS INGLESA E NORTEAMERICANA.

ORIENTADORA: PROFA. DRA. ANNA MARIA GRAMMATICO CARMAGNANI 


\section{AGRADECIMENTOS}

À minha orientadora, Profa. Dra. Anna Maria G. Carmagnani, pela amizade, constante estímulo e confiança durante todo o período dos meus estudos de pósgraduação, e por suas valiosas contribuições para esta dissertação.

Ao Prof. Dr. Lynn Mário T. Menezes de Souza e à Profa. Dra. Marisa Grigoletto, pelo apoio e pelas orientações dadas no exame de qualificação.

A todos os meus colegas da rede particular de ensino de línguas, cujos depoimentos e reflexões formam o ponto de partida para as questões discutidas nessa dissertação.

À Inês Teixeira Barrancos, pela confiança e por ter cedido uma de suas transcrições para este trabalho.

Aos meus colegas do grupo de estudos, coordenado pela Profa. Dra. Anna Maria G. Carmagnani, pelo companheirismo e pelas discussões que auxiliaram meu crescimento.

A meus amigos e familiares, em especial meu marido José Nilton e meu filho Bruno, por terem sempre acreditado na realização deste sonho. 
Para meus pais, Antonio Celso e Ignez, pela vida que me deram e por terem me ensinado o valor da educação. 
BANCA EXAMINADORA: 
"Ao invés de tomar a palavra, gostaria de ser envolvido por ela e levado bem além de todo começo possível. Gostaria de perceber que no momento de falar uma voz sem nome me precedia há muito tempo: bastaria, então, que eu encadeasse, prosseguisse a frase, me alojasse, sem ser percebido, em meus interstícios, como se ela me houvesse dado um sinal, mantendo-se, por um instante, suspensa. Não haveria, portanto, começo: e em vez de ser aquele de quem parte o discurso, eu seria, antes, ao acaso de seu desenrolar, uma estreita lacuna, o ponto de seu desaparecimento possível."

Michel Foucault (A Ordem do Discurso, 1971/1999) 


\section{ÍNDICE}

INTRODUÇÃO 1

CAPÍTULO 1: A Instituição Focal e o Projeto de Ensino Reflexivo 7

1. A instituição 8

2. O projeto de Ensino Reflexivo 9

2.1 Ensino Reflexivo 9

2.2 Os objetivos do Ensino Reflexivo na instituição focal 10

2.2.1 O começo do projeto na instituição 12

2.2.2 As primeiras mudanças e seus pressupostos 14

2.2.3 As reuniões de Ensino Reflexivo 16

2.2.4 Os Planos de Ação 18

2.2.5 O momento da pesquisa 20

2.2.5.1 O Ciclo de Aprendizagem Experimental 20

2.2.5.2 As conseqüências da implantação do ciclo 22

3. Os sujeitos da pesquisa 23

3.1 Os professores informantes 23

3.2 A gerência da filial focal 25

3.3 A pesquisadora 25

4. Conclusão 25

CAPÍTULO 2: O Discurso Neoliberal no Instituto de Línguas 28

1. O Projeto Neoliberal 28

1.1 Qualidade Total e Educação 31

2. Qualidade Total no instituto de línguas 34

2.1 A mudança dos papéis 35

2.2 A necessidade de engajamento 41

2.3 A aula com qualidade 46

2.4 A satisfação do cliente 48

2.5 A constante avaliação $\quad 51$

3. Conclusão 54 


\section{CAPÍTULO 3: O Controle do Discurso}

1. Foucault e a ordem do discurso 57

2. As reuniões de Ensino Reflexivo 62

2.1 O controle do discurso nas reuniões 63

2.2 A reflexão construída/ imposta 73

3. Conclusão 83

CAPÍTULO 4: O Discurso dos Professores 85

1. As entrevistas 85

1.1 O local das entrevistas $\quad 86$

1.2 A fragmentação das identidades do pesquisador/pesquisado 87

2. A dualidade Ensino Reflexivo/ Qualidade Total 93

$2.1 \mathrm{O}$ (não) engajamento 94

2.2 O discurso educacional 98

2.2.1 As vozes dos professores 101

2.2.1.1 O professor ideal 103

2.2.1.2 O professor faz demais 105

2.2.1.3 O professor assume a culpa 106

2.2.1.4 O professor racional 107

2.3 O discurso da Qualidade Total 108

3. Conclusão 114

CONSIDERAÇÕES FINAIS $\quad 117$

REFERÊNCIAS BIBLIOGRÁFICAS 122 


\section{RESUMO}

A presente dissertação tem como objeto de estudo o discurso produzido durante a implantação de um programa de treinamento em serviço (Ensino Reflexivo) em uma instituição de ensino de inglês como língua estrangeira. Nossa hipótese norteadora é a de que o discurso neoliberal de Qualidade Total constitui o discurso educacional do programa de treinamento em serviço de um instituto de línguas, funcionando como um mecanismo de controle, conforme proposto por Foucault (1971/1999; 1987/2000;1979/2000; 2000; 1988/2001).

Para a descrição e interpretação do microcosmo deste trabalho, que é constituído pela escola de línguas, documentos, notas de campo e depoimentos de professores e gerentes participantes do treinamento, adotamos a perspectiva da pesquisa etnográfica. Quanto à análise da materialidade lingüística das interações ocorridas durante as reuniões e entrevistas, o quadro teórico-metodológico utilizado é o da Análise do Discurso de Linha Francesa.

Procura-se, então, examinar como a estruturação do projeto colaborou para a manutenção das relações de poder e saber previamente estabelecidas. Discute-se, também, a constituição do discurso dos professores e a pluralidade de vozes que os constituem não apenas como professores, mas como sujeitos numa sociedade, produzindo uma série de antagonismos em seus enunciados, influenciados tanto pelos princípios pedagógicos como pelas noções e idéias neoliberais. 


\begin{abstract}
The object of study of this dissertation is the discourse produced during an in-service training program (Reflective Teaching) in an institution where English is taught as a foreign language. Our central hypothesis is that the neoliberal discourse of Total Quality constitutes the pedagogical discourse of the in-service training program of a language school, functioning as a mechanism of control, according to Foucault (1971/1999; 1987/2000;1979/2000; 2000; 1988/2001).
\end{abstract}

From the perspective of the ethnographic research, we both describe and interpret our context, which is composed by the language school, documents, field notes and interviews made with both teachers and managers who participated in the training program. As to the analysis of the linguistic materiality of the interactions that took place during the meetings and interviews, we adopt the theoretical framework of the French school of Discourse Analysis.

What is sought, then, is to show how the structuring of the project has helped the maintenance of the formerly established power and knowledge relationships amongst the participants of the program. We also discuss how teachers' discourse is constituted and the multiplicity of voices that constitute them not only as teachers, but as subjects in a society, producing a series of contradictions in their words, influenced by pedagogical beliefs as well as neoliberal notions and concepts. 


\section{INTRODUÇÃO}

O interesse em realizar esta pesquisa surgiu juntamente com a oportunidade de atuar como professora e multiplicadora da instituição estudada. Tendo exercido a função de professora de inglês como língua estrangeira na instituição por aproximadamente cinco anos quando iniciei este estudo, pude presenciar a implementação do projeto de Ensino Reflexivo (Richards \& Lockhart, 1994), além de participar de diversas discussões acerca de sua importância para o docente, tanto em reuniões como junto aos meus colegas.

$\mathrm{Na}$ posição de professora, muitas vezes me questionava se o projeto realmente funcionaria em seu objetivo de mudar concepções enraizadas nos professores sobre sua prática. Nesse sentido, eu fazia parte do grupo de professores que viam o Ensino Reflexivo com descrença, tratando-o como a outras mudanças de ordem metodológica da história do ensino de línguas (Brown, 1994) que eu havia presenciado como aluna de língua estrangeira (no caso dos Métodos Direto e Áudiolingual) ou como professora (o Ensino Comunicativo). Apesar de o Ensino Reflexivo não ser um novo método, mas sim uma postura a ser seguida no treinamento dos professores, pude perceber que o sentimento dentro do grupo era que o Ensino Reflexivo seria desenvolvido até que outra novidade surgisse.

À medida que meu interesse pela reflexão crítica como maneira de alcançar um melhor entendimento acerca do ato de ensinar foi aumentando, crescia também minha disposição em usar a sala de aula como foco de pesquisa, motivada pelos meus estudos (como aluna especial de pós-graduação) sobre pesquisa etnográfica. Como o Ensino Reflexivo também via nas práticas de ensino um foco para a pesquisa e reflexão, julguei que poderia aliar meu trabalho e minha experiência como professora de EFL (English as a Foreign Language) em um instituto de línguas a um projeto que estudasse os efeitos de uma abordagem reflexiva sobre as aulas. 
Contudo, enquanto a implantação do projeto de Ensino Reflexivo evoluía, pude notar o crescente interesse (e por que não insistência) da direção da escola em fazer, antes de qualquer reunião pedagógica, um resumo das últimas pesquisas sobre o crescimento do número de alunos na filial onde lecionava. Essas pesquisas ora mencionavam o número de alunos que haviam deixado a instituição durante o semestre letivo, ora traziam os resultados das pesquisas de satisfação ou mesmo as metas numéricas a serem alcançadas pela filial no semestre seguinte. Isso causava um certo desconforto, não só a mim como a muitos docentes que viam nessa atitude da direção uma tentativa de responsabilizar os professores pelo alcance das metas.

Um outro fato que também me intrigava era a maneira como as pesquisas de avaliação do curso eram feitas, de forma a primarem por respostas fechadas dos alunos. Dessa maneira, apenas o resultado em percentual era enfatizado, não os possíveis desvios ou mesmo alguma colocação que o aluno pudesse ter feito sobre a qualidade da aula. Essa abordagem de pesquisa me parecia empresarial, e portanto não deveria, no meu ponto de vista, ser ressaltada já que a escola deveria estar mais interessada no desenvolvimento pedagógico do aluno, e não no número de matrículas.

Muitas vezes, durante as reuniões pedagógicas de Ensino Reflexivo, os professores se mostravam dispostos a discutir as possíveis razões para as pesquisas estarem ou não de acordo com as metas. Ao mesmo tempo, queriam discutir como a reflexão sobre sua prática de ensino poderia promover o aumento da satisfação com o curso. Porém, qualquer questionamento a esse respeito não era visto como pertinente durante as reuniões, pois estas eram dirigidas apenas à reflexão sobre o microcosmo da sala de aula, e não a críticas sobre a maneira como a instituição conduzia seus cursos.

No segundo semestre de 1999, fui convidada a participar das reuniões de Ensino Reflexivo como professora-multiplicadora. A partir de então, pude ter uma melhor visão da organização do projeto. Nessa posição, outros detalhes sobre como as 
reuniões deveriam ser conduzidas me chamaram a atenção, em especial o tipo de produção de conhecimento que era esperado das mesmas. Além disso, eu também tinha acesso mais freqüente à gerência da filial estudada, e discutia com ela quais seriam os objetivos para cada reunião.

Ao mesmo tempo, continuava a compartilhar das dúvidas e das necessidades dos meus colegas professores, além de também estar preocupada com o sucesso da escola. Se o projeto de Ensino Reflexivo era, antes de tudo, um projeto que proporcionaria um desenvolvimento qualitativo na maneira como o professor conduzia sua aula, por que a direção da escola estava tão preocupada com as metas numéricas? Qual seria a razão pela qual a direção estava sempre pressionando os professores com o número de alunos? Sem dúvida, a escola precisa do lucro para funcionar, mas por que deixar que só o aspecto quantitativo fosse levado em consideração?

Esses questionamentos me levaram a escolher o tema para esta dissertação. Desse modo, defini como objeto de análise a formação de professores, que explorarei através da observação de um programa de treinamento proposto por uma instituição de ensino de inglês como língua estrangeira.

Os textos utilizados nesta pesquisa são de transcrições de gravações feitas no ano de 2000, aproximadamente quatro anos após o início do projeto. Elas são compostas de quatro reuniões de Ensino Reflexivo gravadas em vídeo e outras duas em áudio, além de quatro entrevistas em áudio com os professores e duas com gerentes. Foram também consideradas anotações e apontamentos informais, bem como relatórios sobre as reuniões escritos pelos treinadores. Todos os professores, além da Gerente e Gerente Assistente, são provenientes da mesma filial e estavam na instituição desde o início do projeto. As entrevistas foram gravadas na própria filial estudada em datas diferentes de maio a agosto. 
As perguntas das entrevistas foram elaboradas a partir da observação não só das reuniões como também das reações dos professores diante do objetivo proposto no primeiro semestre de 2000, que era a implantação do Ciclo de Aprendizagem Experimental nas aulas. Elas tinham como objetivo levar os próprios professores a tentar explicar o que o Ensino Reflexivo significava para cada um deles, o que havia mudado desde sua implantação e quais as conseqüências do projeto tanto para a instituição como para o professor e o aluno.

Já as perguntas feitas para a gerência da filial estavam focadas não só na sua visão do projeto, mas na expectativa da instituição quanto aos seus resultados, na possível resistência dos professores, bem como na relação existente entre o Ensino Reflexivo e a implementação da gerência de Qualidade Total que também fazia parte das recentes mudanças administrativas da instituição. As entrevistas com as gerentes ocorreram após a gravação e análise da maioria das reuniões de Ensino Reflexivo e das entrevistas com os professores, num momento em que a Qualidade Total já demonstrava ser um componente importante para esta dissertação. Por esse motivo, ela havia se tornado tema de uma das perguntas.

Durante a análise do corpus da pesquisa, pude identificar a presença marcante de alguns discursos. Porém, tendo em vista as limitações deste trabalho, optei pelos seguintes recortes: o discurso da gerência e o discurso dos professores.

A partir dessa escolha, concentrei minhas leituras em obras que tratam de administração educacional, filosofia, sociologia da educação e ensino de línguas, para usá-las como base para minha análise.

A hipótese norteadora deste trabalho é a de que o discurso neoliberal de Qualidade Total constitui o discurso educacional do programa de treinamento em serviço de um instituto de línguas, funcionando como um mecanismo de controle, conforme proposto por Foucault (1971/1999; 1987/2000;1979/2000; 2000; 1988/2001). 
Procurei, então, buscar respostas para as seguintes perguntas de pesquisa, com base no corpus estudado:

1. Como é construído o discurso do Ensino Reflexivo dentro da instituição observada e quais os saberes/sentidos produzidos por esse discurso?

2. Como são estabelecidas as relações de poder nesse contexto?

3. Como o discurso da Qualidade Total se articula com o programa de treinamento em serviço proposto pela escola?

4. Como são constituídas as identidades dos professores do programa de Ensino Reflexivo?

Optei por desenvolver esta dissertação em quatro capítulos, além da introdução e da conclusão. No Capítulo 1, discutirei as condições de produção desta pesquisa, 0 instituto de línguas focalizado, o cenário sócio-histórico (que leva em consideração o projeto de Ensino Reflexivo), bem como os sujeitos participantes.

No Capítulo 2, abordarei o projeto neoliberal de Qualidade Total e como ele está ligado ao projeto de Ensino Reflexivo. Discutirei algumas características do discurso de Qualidade Total na educação e como ele se apresenta no instituto de línguas focal através das noções de engajamento, satisfação e qualidade de serviços.

Nos Capítulos 3 e 4, discutirei questões relativas a AD de linha francesa conforme Pêcheux (1969; 1975; 1997), a partir da perspectiva retomada pelos trabalhos de Orlandi (1999) e Brandão (1991), para analisar o discurso dos professores e dos gerentes da filial estudada através da materialidade lingüística dos enunciados produzidos pelos mesmos durante nossos encontros (tanto em reuniões de Ensino Reflexivo como em entrevistas individuais).

Assim, no Capítulo 3 procurarei estabelecer como se dá a construção dos sentidos nas reuniões de Ensino Reflexivo e como o controle do discurso é estabelecido. Discutirei alguns enunciados produzidos nas reuniões que foram gravadas no 
primeiro e segundo semestres de 2000, fazendo uma ligação entre o que foi produzido nessas reuniões e a fala da gerência geral do departamento acadêmico para os professores de todas as filiais (também ocorrida no início do segundo semestre de 2000). Para tanto, organizo a discussão em dois tópicos: o controle do discurso e a reflexão construída e/ou imposta. Usarei a teoria de Foucault (1971/1999) sobre a ordem do discurso como base para a discussão.

Já no Capítulo 4, verificarei como se dá o jogo de identidades e a pluralidade de vozes nas entrevistas feitas com os professores. Discutirei alguns problemas relacionados com as condições em que ocorreram as entrevistas e seus efeitos nos enunciados, além de algumas contradições com respeito ao engajamento e aceitação do projeto pelos professores. Constato que a fala destes é constituída não só pelo discurso educacional, mas também pelo discurso institucional, estando os dois em constante embate. Por fim, discutirei como o discurso dos professores se relaciona com o discurso educacional do Ensino Reflexivo bem como com o discurso neoliberal de Qualidade Total. 


\section{CAPÍTULO 1:}

\section{A Instituição Focal e o Projeto de Ensino Reflexivo}

Este capítulo tem por objetivo situar como o programa de Ensino Reflexivo foi implantado na instituição de ensino estudada. Procuramos, assim, criar um conhecimento a partir da observação de um fenômeno vivo. Para tanto, optamos pela metodologia etnográfica (Hammersley \& Atkinson:1983; Hammersley:1994; Van Lier :1988; e Watson-Gegeo:1988) para a descrição e interpretação do contexto estudado, pois foi essa postura que orientou a seleção do tema da dissertação. Nosso olhar sobre os dados coletados na fase de observação resultou na elaboração das perguntas de pesquisa.

Watson-Gegeo (1988: 576) postula que o objetivo do etnógrafo é promover não só uma descrição, mas também uma avaliação interpretativa do que as pessoas fazem num determinado contexto, do resultado de suas interações e da maneira como essas pessoas entendem o que acontece. Apesar de o nosso objetivo neste primeiro capítulo não ser escrever uma etnografia, entendemos que a compreensão do processo de implantação do projeto pode nos levar a uma reflexão sobre como atuam esses programas de treinamento na formação do professor de língua estrangeira.

Hammersley \& Atkinson (1983: 2) também apontam a etnografia como uma forma de pesquisa social, em que o etnógrafo participa da rotina de um grupo coletando qualquer tipo de informação que possa ser importante para o tipo de conhecimento que ele procura promover. Para isso, o pesquisador faz uso de uma abordagem qualitativa de pesquisa ${ }^{1}$.

\footnotetext{
${ }^{1}$ É importante ressaltar que Watson-Gegeo (op. cit.) aponta para a diferença entre a etnografia e a pesquisa qualitativa, apesar de elas serem freqüentemente tratadas como sinônimos. A autora ressalta que o termo "qualitativo" se aplica também a outros tipos de abordagens e técnicas de pesquisa, como o estudo de casos, análise de conteúdo e semiótica, entre outros. A pesquisa etnográfica é qualitativa, mas difere das outras formas de pesquisa por ser holística e tratar a cultura como parte integral da análise.
} 
Em nosso caso, é necessário salientar que o observador não é estranho ao meio. $\mathrm{Na}$ fase da coleta de dados, a pesquisadora já trabalhava na instituição havia cinco anos, sendo que durante o primeiro semestre havia lecionado em outra filial. Isso proporcionou um conhecimento maior sobre a instituição e facilitou o acesso a documentos e conversas informais com os funcionários. Além de ministrar aulas, ela exercia a função de professora-multiplicadora (uma das peças-chave do projeto a ser descrita neste capítulo) havia seis meses. Essa riqueza de fontes faz deste relato uma descrição detalhada do cenário da pesquisa.

Num primeiro momento, destacaremos a instituição de ensino que é foco desta pesquisa. Como procuraremos analisar uma experiência de Ensino Reflexivo em um instituto de línguas, apresentamos um panorama dos pressupostos do Ensino Reflexivo e como eles se aplicam à instituição estudada. Além disso, discutiremos algumas mudanças ocorridas durante a coleta dos dados e os sujeitos envolvidos tanto nas reuniões como nas entrevistas.

\section{A Instituição}

A escola de línguas da qual falaremos é uma das 14 filiais de uma instituição de origem britânica que estava no país há 65 anos no momento da pesquisa e ministra aulas de inglês como língua estrangeira para alunos a partir dos sete anos de idade, com diferentes níveis de proficiência. Suas filiais estão localizadas na sua maioria na cidade de São Paulo, com outras escolas em Campinas, Guarulhos, Santo André e Santos, além de joint-ventures e cursos em empresas e dentro de escolas da rede particular, totalizando aproximadamente 40.000 alunos na época da pesquisa.

Essa instituição prima pela tradição no ensino e por larga experiência em treinamento e preparação de professores. Além disso, tem como missão levar a língua inglesa para o maior número de pessoas possível, o que nos remete ao discurso colonialista e à idéia da missão civilizadora da nação britânica conforme Pennycook (1998). É como se a escola estivesse também cumprindo o seu papel colonizador, sendo a detentora do novo e progressivo saber contido nos 
treinamentos e cursos que oferece, como quando "...the Empire became the central testing site for the development of ELT..." (Pennycook, op. cit.: 131). O projeto de Ensino Reflexivo (Reflective Teaching) é, então, testado na instituição assim como num local onde teorias são manipuladas e novos saberes produzidos.

Cada filial conta com uma pessoa no cargo de Gerente e outra no de Gerente Assistente (quando o número de alunos ultrapassa 2.500), encarregadas dos assuntos administrativos. Essa nomenclatura surgiu junto com a aplicação do programa de Qualidade Total. Anteriormente, a Gerente era a Superintendente da filial enquanto a Gerente Assistente era a Supervisora Assistente. As atribuições, contudo, continuaram as mesmas.

\section{O Projeto de Ensino Reflexivo ${ }^{2}$}

\subsection{Ensino Reflexivo}

Richards \& Lockhart (1994) defendem o desenvolvimento de uma abordagem reflexiva sobre o ensino. Nela, professores coletariam informações sobre suas práticas de ensino, examinariam suas atitudes e poderiam usar esse material como base para uma reflexão crítica sobre o ato de ensinar. Um dos pressupostos que subjazem a essa abordagem é que um professor informado é aquele que tem um bom conhecimento sobre o que é lecionar. Tanto a reflexão crítica como o uso de técnicas reflexivas podem ajudá-lo a aprender mais sobre sua profissão, pois somente a experiência não é suficiente como base de desenvolvimento, já que muito do que acontece no ensinar normalmente não é percebido pelo professor.

Parker (1997) sustenta que o Ensino Reflexivo (doravante ER) não deve ser confundido com uma mera reflexão sobre o lecionar e por isso sugere um outro valor a esse processo. Em sua visão, a noção de Ensino Reflexivo ainda está presa aos

\footnotetext{
${ }^{2}$ É importante ressaltar que em nosso contexto as expressões "Reflective Teaching", "Reflective Learning" e "Reflective Teaching and Learning" são usadas pela escola para designar um único projeto: o Ensino Reflexivo. A escolha da denominação varia conforme a ênfase dada a cada aspecto pedagógico. Assim, essa última fase contém tanto o Ensinar (Teaching) como o Aprender (Learning) porque enfoca a aula como um todo, englobando tanto o professor e as técnicas (Teaching) como o aluno (Learning). Essa aparente mudança visa amenizar as deficiências presentes no projeto, verificadas através dos mecanismos de medição do mesmo.
} 
conceitos positivistas do "racionalismo técnico" (Parker, op. cit.: 140). Ou seja, sua crítica parte do pressuposto que, apesar da tentativa de emancipação do professor da posição de técnico (que deveria saber como fazer seus alunos chegarem a determinados níveis de eficiência) para educador, a educação continua baseada em generalizações sobre como os fatos podem levar a determinados resultados, priorizando o treinamento em detrimento da educação do professor, o que discutiremos melhor mais adiante.

\subsection{Os objetivos do Ensino Reflexivo na instituição focal}

O projeto de Ensino Reflexivo foi lançado em $1996 \mathrm{com}$ a finalidade de adaptar o programa de formação de professores com vistas a se estabelecer uma nova prática educacional que envolvesse alunos e professores, e deveria atingir o seu melhor momento em torno de cinco anos. O sucesso dessa proposta dependeria do engajamento dos professores "num processo de reflexão crítica de sua prática, para melhorar a qualidade de seu trabalho à medida que se tornassem mais sensíveis às necessidades e expectativas de seus alunos para melhor atendê-las " (Tagata, 2000:35).

A única publicação da instituição sobre o tema, a revista Reflections, datada de 15 de fevereiro de 1996, de distribuição interna, revelava em sua capa o objetivo do ER:

Our goal is to foster an atmosphere, based on mutual trust, cooperation, and acceptance of differences, in which on-going questioning and rethinking provokes teachers' curiosity about their teaching and students' learning, and leads to actions which strengthen and improve that relationship.

Além desse objetivo principal que serviria para todas as filiais, cada filial (pela iniciativa de sua gerente) deveria selecionar outras metas a serem atingidas. Essas metas eram divididas em quatro categorias: Saber, Habilidades, Atitudes e Percepção (Knowledge, Skills, Attitudes e Awareness). Na filial em questão, ficou decidido que o projeto deveria "foster teachers' flexibility and rethinking in order to adapt to the new XXX (nome da instituição) students' profile". Ou seja, o ER deveria promover uma maior flexibilidade dos professores em relação ao novo perfil dos 
alunos da escola. Uma possível razão para tal escolha talvez estivesse no fato de a filial em questão, assim como algumas outras, estar presenciando uma mudança no tipo de aluno que recebia. Esse novo aluno era, muitas vezes, de poder aquisitivo mais baixo, e muitos professores já haviam reclamado que esse novo cliente thes causava dificuldade durante a aula, pois era de nível cultural inferior, o que estaria acarretando um maior dispêndio de tempo para o cumprimento do plano de aula.

Na filial estudada, as outras metas para o primeiro semestre de 1997 eram:

Skills (habilidades): analisar os aspectos do ensino/ aprendizado e relacioná-los com o todo de sua prática como professores e do aprendizado de seus alunos.

Attitudes (atitudes): abrir-se a mudanças e novas idéias.

Awareness (percepção): perceber as necessidades e os desejos dos alunos e estabelecer a distinção entre esses dois termos; verificar o que os alunos fazem na aula e como isto se aplica às suas metas e às metas da instituição e seu currículo.

Esses objetivos não eram considerados claros pelos professores, sendo que alguns ainda tinham dúvida quanto à sua utilização ou mesmo eficácia nos primeiros anos. O mesmo acontecia com a gerência das filiais, composta por uma gerente e uma gerente auxiliar. Além disso, essa foi a única vez que os objetivos do ER foram claramente expostos. A partir do segundo ano, as metas eram relacionadas nos relatórios dos professores-multiplicadores, mas seria difícil encontrar um professor que se lembrasse de alguma. A edição da revista Reflections não havia mais circulado, embora muitos professores mais novos nem soubessem de sua existência.

Nessa mesma publicação encontra-se um pequeno resumo em que são relatados os primeiros meses do projeto, além de uma série de textos das primeiras pessoas nele envolvidas, como gerentes, membros do departamento acadêmico ou mesmo os professores-multiplicadores. 
A função de professor-multiplicador (doravante PM) foi criada para auxiliar o departamento acadêmico na disseminação das idéias do projeto. Professores escolhidos em cada filial pela gerência fariam cursos junto ao departamento acadêmico e teriam a função de multiplicar seus conhecimentos para o restante do corpo docente das filiais -- adaptando-os quando necessário-- através de reuniões mensais.

Esses PMs fariam um revezamento, ficando aproximadamente um ano no cargo. Apesar de ter sido apenas um no primeiro semestre do programa, logo no segundo semestre as filiais contavam com dois deles, sendo que a cada seis meses um novo multiplicador fazia par com um outro que já estivesse na função há seis meses. Dessa maneira era assegurado o fluxo de conhecimento, e cada novo PM ficava a par do que havia acontecido durante as reuniões entre o departamento acadêmico e os outros multiplicadores antes de ele assumir o posto.

Os PMs também eram considerados uma ligação entre os professores e a instituição. Nem todos eram bem-aceitos pelos professores, já que sua escolha era feita com base na percepção dos gerentes, mas a maioria era considerada parte do grupo. Apesar de não ser um cargo à parte, o PM gozava de um certo prestígio na filial, pois não deixava de ter uma posição de destaque em relação aos outros professores. Além disso, os professores que permaneciam na função de multiplicadores passaram a ser os primeiros a receber bolsas de estudo no exterior, além do fato de que o exercício da função era levado em conta para futuras promoções.

\subsubsection{O começo do projeto na instituição}

No início de 1996, quando o curso de nível intermediário foi implantado na instituição baseado no Task-based Approach (TB), foi decidido que, a princípio, somente os professores que estivessem ensinando esses grupos (aproximadamente 150) fariam parte do ER. O modelo de aula a ser seguido no nível intermediário seria um pouco diferente do PPP (abreviação de Presentation- Practice- Production, ou 
Apresentação, Prática e Produção) que era seguido regularmente. No PPP a aula consistia em uma apresentação da língua alvo dada pelo professor, seguida por um período de prática em que as estruturas/ vocabulário/ funções eram trabalhadas até que pudessem ser produzidas de maneira mais natural.

Scrivener (1994) comenta o PPP ao falar das abordagens que são geralmente usadas principalmente para o ensino de gramática. Ele vê o PPP como uma metodologia em que pequenos pedaços da língua são previamente selecionados pelo professor para exemplificar alguma estrutura. A partir daí, cada item é revisado até que os alunos se familiarizem com ele e, eventualmente, o internalizem. Esse tipo de formato de aula estaria na categoria de "ordem lógica" de aula, que Scrivener (op. cit.) descreve como o tipo de aula em que cada atividade leva à atividade seguinte. Como exemplo, poderíamos citar uma aula de gramática em que primeiro entenderíamos um item; depois o praticaríamos através de exercícios direcionados; a seguir, haveria uma prática mais aberta (ou seja, aquela em que o aluno pudesse experimentar um pouco mais com a língua, apesar de ainda ser dirigida) para, por fim, executarmos algum tipo de exercício escrito ou oral mais livre para consolidar nosso entendimento.

Já o Task-based Approach partia do pressuposto de que o aprendiz seria beneficiado se o seu curso fosse organizado de maneira a levá-lo à solução de tarefas em que ele normalmente se envolve fora da sala de aula (Brown:1994). Assim sendo, ele seria exposto a uma situação e estaria mais propenso a aprender a língua para conseguir executar suas tarefas. O aluno teria diante de si uma variedade de linguagem autêntica e deveria utilizar sua própria experiência e conhecimento para analisar e experimentar com a língua. Apesar das duas maneiras de apresentação de aulas (PPP e Task-based) serem relacionadas ao Ensino Comunicativo (Brown, 1993;1994), este seria apenas o princípio de uma mudança radical nos moldes da aula tradicionalmente dada na escola. 
Como o projeto também visava a uma certa descentralização do processo de treinamento, os gerentes e os multiplicadores foram convidados a fazer parte do treinamento oferecido por consultores externos.

\subsubsection{As primeiras mudanças e seus pressupostos}

Para que essa descentralização seja melhor entendida, é necessário apontar algumas mudanças nos papéis dos sujeitos envolvidos e no sistema de treinamento, as quais contribuiriam, segundo a gerente de operações da instituição, "...to the overall well-being of the XXX". Essas mudanças estavam centradas não só no papel da gerência, do departamento acadêmico e na maneira como as observações de aulas eram encaradas, mas principalmente na solução de problemas levantados pelos alunos e professores, influência clara do discurso de Qualidade Total que permeia todo o ER, conforme discutiremos no Capítulo 2 (página 28).

De acordo com o resumo apresentado pela gerente de operações da instituição na revista Reflections, as mudanças poderiam ser visualizadas a partir das noções de antes e depois do projeto. Destacaremos a seguir as três principais diferenças de parâmetros seguidas pelo ER relacionadas tanto com a gerência como com os professores:

No modelo de gestão anterior, o departamento acadêmico era o responsável por todos os programas de treinamento da instituição, e deveria apresentar "receitas" de aulas que seriam seguidas pelos professores. A gerência não se envolvia nesse treinamento. Agora, a gerência era responsável pelo sucesso do projeto, assim como o professor que não receberia mais modelos, e deveria assumir uma posição de engajamento pessoal. O treinamento ainda era dado pelo departamento acadêmico, mas a gerência deveria estar mais atenta a ele, participando das reuniões de treinamento em serviço (in-service training), por exemplo. 
Ressaltamos nesse item a preocupação da escola com o valor pedagógico que permeia todo o processo de reflexão proposto pelo ER. Esse aspecto nos remete a uma noção qualitativa do $\mathrm{ER}$, segundo a qual os professores seriam eficientes à medida que estivessem conscientes das implicações sociais da prática e política educacionais (Parker, 1997). Os treinamentos, segundo essa postura, priorizariam a reflexão sobre a aula como processo, e não como uma mera série de atividades.

Anteriormente, as observações de aulas feitas pela gerência (da filial ou acadêmica) eram focadas no ensino (em oposição a aprendizado) e levavam a um julgamento de valor (por exemplo, a aula e o professor eram bons ou ruins). Os professores se concentravam em demonstrar o conhecimento de técnicas de ensino e em obter um conceito positivo na avaliação. Na "nova" visão, a gerência e o professor focalizariam a observação no aprendizado do aluno, sendo o professor avaliado em relação a esse aprendizado e convidado a refletir sobre um possível plano de ação para as próximas aulas.

Esse novo olhar sobre o acontecimento "aula" demonstra uma visão mais reflexiva e qualitativa sobre o que acontece na sala de aula, o que sugere, mais uma vez, atenção ao processo (ao plano de aula e seus pressupostos) e não ao produto final (a aula dada). Ao mesmo tempo, expõe uma certa fragilidade na maneira como é enfatizado o aprendizado que ocorre em sala de aula, se tomamos como pressuposto que não é possível avaliar se acontece ou não o aprendizado em apenas uma aula, nem mesmo se o que foi aprendido é aquilo que o professor tinha em mente. Parece ser mais correto entender esse "aprendizado" como um exemplo de produção ou mesmo um reconhecimento da língua alvo (target language) trabalhada em sala (Brown,1993).

Antes do ER, a solução dos problemas mencionados pelos professores e alunos ficava a cargo da gerência da filial, e, em consonância com o modelo, os professores imaginavam que o gerente era a pessoa indicada para resolver tais problemas. No ER, os problemas são transformados em desafios a serem 
discutidos pelos professores, os quais assumem a posição de solucionadores, o que estimularia o trabalho em grupo.

Para que possamos entender o porquê dessas mudanças, é importante lembrarmos que o projeto foi iniciado na mesma época em que era implantada a Gerência de Qualidade Total na organização. Isto explica várias mudanças no sistema de operação da instituição, a começar por mudanças sutis relacionadas à denominação de cargos ou papéis representados pelas pessoas envolvidas, momento em que a superintendente da filial passa a ser chamada de gerente e o aluno se torna, mais do que nunca, um cliente. É evidente que a essa troca de palavras subjazem os efeitos provocados pelo discurso de Qualidade Total. Segundo Marcello (2000:71):

O principal objetivo da teoria da qualidade total é estabelecer um sistema específico de administração, centrado no atendimento das necessidades, interesses e expectativas dos clientes. Para atingir este objetivo é necessário que todos os indivíduos de uma dada organização social estejam engajados na implementação dos princípios da qualidade total. (2000:71)

Como a escola de línguas é também uma empresa, é primordial que seus alunos estejam satisfeitos com os serviços oferecidos (as aulas). Assim, ao investir no treinamento contínuo dos professores, a instituição estudada mostra que está de acordo com um dos pressupostos da Qualidade Total (Amarante, 1998; Marcello, 2000), que é o empenho contínuo das empresas em melhorar seus produtos e processos.

Um outro exemplo de adequação está na visão do professor como peça fundamental para a satisfação dos clientes. Nesse sentido, ele é um prestador de serviços que deve se apresentar como exemplo de um profissional que se preocupa em detectar problemas, questionar melhorias, gerar soluções e efetivar mudanças.

\subsubsection{As reuniões de Ensino Reflexivo}

Como já foi mencionado, num primeiro momento, o treinamento dos gerentes, de seus assistentes, dos membros do departamento acadêmico e dos multiplicadores 
foi feito por um consultor externo especializado em Ensino Reflexivo (tanto em fevereiro como em julho). O ER foi então apresentado aos demais professores no mini-curso semestral dado pela instituição a seus professores, chamado de "Refresher Course", e no final de março de 1996 as filiais tiveram suas primeiras reuniões com os multiplicadores.

Essas reuniões não eram obrigatórias a princípio, apesar de a gerência mencionar claramente quanto elas significavam para o crescimento profissional do professor e mesmo da instituição. Dessa maneira, foi criada uma necessidade de engajamento no corpo docente pelo atrativo da realização profissional. Mais adiante, quando todo o grupo de professores já estava envolvido, as reuniões se tornaram não só obrigatórias como também uma maneira de medir o grau de engajamento dos professores no projeto, como veremos nas entrevistas com a gerente da filial estudada. Isto nos remete a Foucault (1979/2000) e sua teoria de circulação de poder em que ele discute a maneira como o poder circula em todas as camadas de uma instituição para ser eficaz:

Se o poder fosse somente repressivo, se não fizesse outra coisa a não ser dizer não você acredita que seria obedecido? O que faz com que o poder se mantenha e seja aceito é simplesmente que ele não pesa só com uma força que diz não, mas que de fato ele permeia, produz coisas, induz ao prazer, forma saber, produz discurso. (1979/2000:8)

Assim, ao garantir o comprometimento dos professores com a necessidade de aprimoramento pedagógico, a escola poderia reduzir a resistência dos docentes ao discurso de qualidade total. A visão do docente como prestador de serviços foi muito criticada pelos professores durante as entrevistas, bem como o aluno no papel de cliente. A razão apontada pelos entrevistados era que a escola, ao visar a satisfação dos desejos dos clientes acima de tudo, havia causado prejuízo para o aprendizado. Conseqüentemente, o nível de satisfação do cliente caiu, o que provocou sérias mudanças no momento de nosso estudo, conforme análise no Capítulo 4 (página 85). 


\subsubsection{Os Planos de Ação}

Voltando ao início do segundo ano do ER, tanto multiplicadores como professores começaram a preparar os MLAPs e TLAPs (os Planos de Ação dos Multiplicadores e Professores), cujo papel era auxiliar a reflexão dos professores em torno de assuntos relacionados à sua prática. Os professores (e também PMs num primeiro momento) eram convidados a escolher um foco que poderia estar relacionado a diversos temas, por exemplo a disciplina, como promover maior fluência escrita ou oral, entre outros. Poderiam também escolher as classes ou níveis de proficiência em que gostariam de estar trabalhando.

Com o passar do tempo, não só os Planos de Ação foram ficando cada vez mais detalhados, como até mesmo a observação de aulas da filial focalizada começou a ser feita com base nesses planos. Eles eram chamados de "documentos" pela gerente, e houve muita discussão quanto à ênfase dada a esses planos de ação em detrimento do restante das aulas ou de outras questões com as quais os professores também lidavam. A avaliação dos planos pela gerência também foi alvo de muitas críticas por parte do corpo docente, como veremos mais adiante nas entrevistas.

A primeira sessão de PMs do semestre era geralmente dedicada ao planejamento dos Planos de Ação, enquanto no final de cada semestre os professores tinham que preparar uma avaliação sobre o seu progresso para a gerência. No último semestre da pesquisa, foi pedido aos professores da filial em questão um trabalho de no mínimo 350 palavras sobre a evolução de seus Planos de Ação durante esse período, inclusive com bibliografia. Como forma de coerção, foi mencionado que os trabalhos seriam considerados para concessão de futuras promoções e viagens ao exterior. Dependendo da filial, a evolução dos planos poderia ser tanto acompanhada pelos multiplicadores como pela gerência.

Contudo, estes não eram os únicos mecanismos de controle de produção do Ensino Reflexivo. Além das reuniões mensais dos multiplicadores com os professores contarem sempre com um representante do departamento acadêmico ou mesmo 
com a presença do gerente da filial, ficou instituído que os multiplicadores escreveriam dois relatórios a cada reunião. O primeiro era relativo ao conteúdo e ao processo da mesma, cabendo aos multiplicadores dar explicações de como a sessão havia transcorrido e apontar quais os tipos de problemas levantados, bem como conclusões e possíveis planos de ação para uma próxima sessão. O segundo relatório só era escrito após uma reunião chamada de "Guiding Coalition", na qual dois PMs, as gerentes, uma pessoa do departamento acadêmico e mais dois professores convidados discutiam a avaliação formal fornecida pelos professores através de questionários. Nessa reunião eram discutidas as percepções dos PMs e dos professores sobre as questões tratadas durante a sessão e também a atitude do grupo perante tais questões, além dos próximos passos a serem seguidos.

Esses relatórios não eram entregues ao departamento acadêmico por todas as filiais, sendo que muitos multiplicadores passaram a discutir sua validade, em especial porque não era conhecido o destino dos mesmos. Enfim, os relatórios pareciam ser por demais burocráticos e não ajudavam as discussões.

Em agosto de 1999, foi criada uma lista de discussão no sítio da instituição que deveria ser usada apenas pelos multiplicadores como uma oportunidade de reflexão sobre o que acontecia nas demais filiais em relação ao projeto. Os multiplicadores foram convidados a expor dúvidas, dividir planos de sessões ou mesmo discutir os próximos passos. Por mais que se desse ênfase à lista como meio de comunicação entre multiplicadores, o que ocorreu, com raras exceções, foi a procura do apoio do membro do departamento acadêmico responsável pelo projeto às idéias dos multiplicadores e a descrição de sessões realizadas, sem que houvesse muita discussão sobre os acontecimentos. Como a lista só funcionou durante um semestre, podemos presumir que ela acabou não promovendo o intercâmbio de informações pretendido pela instituição. 


\subsubsection{O momento da pesquisa}

No primeiro semestre de 2000, o objetivo principal do ER era a implantação do Ciclo de Aprendizagem Experimental (Experiential Learning Cycle) nas aulas. O projeto, que havia começado com a adoção do Task-based Approach, passaria por mudanças radicais quando os professores começassem a utilizar esse outro modelo na preparação de suas aulas. Juntamente com as aulas, mudava-se a visão de aprendizagem da instituição e tentava-se reestruturar os cursos sob um outro paradigma. O papel do professor estaria mais ligado à visão sócio-interacionista do aprendizado, segundo a qual ele atuaria como um mediador ou um colega mais capaz, enquanto o aluno participaria da interação e da construção do seu conhecimento (Lightbown \& Spada,1993).

\subsubsection{O Ciclo de Aprendizagem Experimental}

O novo modelo de aulas que surgia na escola era baseado na filosofia educacional de John Dewey (apud Kolb, 1984), além de outros autores que contribuíram para o desenvolvimento da Aprendizagem Experimental (Experiential Learning), como Lewin, Piaget, Freire e Illich (apud Kolb, 1984). Essa abordagem tem como pressuposto a idéia de que a experiência funciona como fonte de aprendizagem e desenvolvimento. Segundo Kolb (op. cit.), o uso do aprendizado experimental que liga desenvolvimento pessoal, educação e trabalho tem contribuído em especial para a educação universitária, pois colabora para que as idéias abstratas da academia possam ser colocadas em exemplos práticos da realidade dos alunos.

Um diferencial do Aprendizado Experimental, segundo Kolb (op. cit.), é o papel central da experiência no processo de aprendizagem, em contrapartida às teorias racionalistas e cognitivas, que tendem a priorizar a aquisição e a manipulação, e às teorias behavioristas, que negam qualquer papel para a consciência e a experiência subjetiva no processo de aprendizagem.

Apesar de Kolb (op. cit.) enfatizar que a aprendizagem experimental não pode ser vista como uma série de técnicas a serem aplicadas, mas sim como um programa 
que recria nossos sistemas sociais, o ciclo que viria a ser usado na instituição era visto como um modelo de aula, baseado nos modelos de aprendizagem de Lewin, Dewey e Piaget.

O primeiro tem como pano de fundo as experiências laboratoriais, em que a experiência concreta leva a observações e reflexões, depois à formação de conceitos e generalizações para, por fim, haver mais testes em novas situações. Já o modelo de Dewey enfatiza o aprendizado como um processo dialético que integra experiência e conceitos, observações e ações, como se a cada ciclo um outro fosse ligado, formando uma espiral. O processo de aprendizagem compreenderia as fases denominadas impulso, observação, conhecimento e julgamento. O modelo de Piaget, identifica as fases do fenômeno concreto, da reflexão internalizada, da construção abstrata e do egocentrismo ativo, que na realidade estão relacionadas com os quatro estágios de crescimento cognitivo (de 0-2, 2-6, 7-11 e 12-15 anos).

Pelos novos parâmetros, uma aula ideal consistiria de:

Experiência concreta: o aluno seria exposto a um ato social, uma tarefa, e tentaria executá-la; ou, no caso de não saber executá-la, o aluno pensaria em que tipo de língua precisaria (funções, vocabulário, etc...)

Observação reflexiva: o aluno teria um modelo (uma leitura, um diálogo do livro, um vídeo) com o qual faria uma comparação entre o que seria o ideal e a sua produção. Neste caso, ele ficaria ciente de que precisaria aprender mais para alcançar seus objetivos.

Conceitualização abstrata: seria o momento da prática em sala de aula. Estando ciente das estruturas que necessitaria para uma melhor performance no seu diaa-dia, o aluno praticaria as estruturas até que elas se tornassem mais familiares.

Experimentação ativa: seria uma nova oportunidade, com uma nova tarefa ou a anterior, que o aluno estaria apto a executar de maneira mais fluente, usando a língua praticada. 
Essa aula poderia se estender por mais de uma hora/ aula, porém era necessário que o ciclo fosse completado para que o aluno tivesse uma noção da construção do seu conhecimento.

Os docentes já haviam ouvido falar do ciclo nos primeiros anos do projeto, porém sob outro prisma: o do aperfeiçoamento pessoal, processo em que eles teriam tido suas experiências concretas (as aulas), as teriam descrito e feito considerações pertinentes ao que teria ou não dado certo em suas práticas. A partir dessa reflexão, os professores deveriam promover planos de ação para solucionar problemas ou implementar suas próximas aulas.

Esses novos parâmetros provocaram muita discussão e até mesmo mudanças no ER, como veremos no próximo item. Nem todos concordavam que aquele era o melhor modelo para todos os tipos de aula, houve muita discussão sobre o tempo gasto pelos professores para que fosse estabelecido um ato social. O ciclo era visto como uma outra versão do Task-based Approach, e, um fato chamou a atenção de alguns professores: os alunos diziam que a aula ficava chata demais.

\subsubsection{As conseqüências da implantação do Ciclo}

Para o segundo semestre de 2000, a estrutura de treinamento dos professores em serviço começou a ser reformulada. Surgiu a figura do Mentor (também exercida por um professor e que será explicada a seguir) nas filiais e o número de multiplicadores foi reduzido para um, além de serem chamados professores que já haviam feito parte do quadro de multiplicadores de volta para a função. A idéia era de que, como apenas um PM teria que preparar as reuniões, era mais desejável que essa pessoa já tivesse um prévio conhecimento de como funcionava o ER. Em algumas filiais foi mantido o último PM, enquanto em outras, como a filial estudada, um exmultiplicador reassumiu a função.

O Mentor, por sua vez, teria uma posição de destaque na filial, sendo um exmultiplicador que não só auxiliaria na observação de aulas e sua preparação, como 
também daria oficinas em datas estabelecidas pela gerência sobre assuntos que interessariam à maioria dos professores. Esses tópicos não teriam conexão com o ER, a princípio, mas sim com a tecnicalidade da aula. Como exemplo, na filial observada, a mentora ofereceu oficinas sobre Prática de estruturas da língua e Técnicas de Correção. Essa necessidade de um professor que auxiliasse foi provocada não só porque os professores haviam ficado confusos com o novo tipo de aula, mas porque o número de professores novos na instituição crescia muito. Se os professores mais experientes já não tinham certeza sobre o que fazer, era necessário que não houvesse dúvidas para aqueles recém-chegados à escola.

Por fim, havia mais um fator de preocupação: o número de alunos da instituição havia diminuído com o passar dos anos de projeto, e na filial em questão o número de alunos decrescia a cada semestre em proporção ainda maior. Era essencial que fosse descoberto em que o ER havia falhado, pois, se o objetivo era adequar o ensino às necessidades e expectativas do aluno, e esse mesmo aluno abandonava a escola, ajustes deveriam ser feitos.

Este é o cenário em que nossa pesquisa está inserida. Nosso corpus, composto por gravações de reuniões de Ensino Reflexivo e por entrevistas com os sujeitos participantes, foi coletado durante o ano de 2000, em meio a mudanças na estrutura do projeto (como a diminuição de PMs discutida acima, por exemplo) e à inquietação causada pela diminuição do número de alunos, conforme discutiremos nos próximos capítulos.

\section{Os sujeitos da pesquisa}

\subsection{Os professores informantes}

Os quatro professores entrevistados faziam parte do corpo docente da escola quando o projeto foi implantado. Nenhum deles era falante nativo da língua inglesa, porém todos tinham a função de professores, graças ao diploma universitário de Letras ou à complementação pedagógica oferecida por algumas faculdades. Todos os professores tinham um bom relacionamento com a pesquisadora, o que facilitou 
para que as entrevistas ocorressem. Além disso, foi possível agendar um horário conveniente tanto para a pesquisadora como para os professores colaboradores.

A primeira professora a ser entrevistada (P1) já ministrava aulas havia 30 anos dentro da instituição. Por sua vasta experiência, lecionava desde os níveis iniciais até os mais altos graus de proficiência para alunos de diferentes idades, e já havia experimentado várias abordagens de ensino de línguas. Apesar disso, continuava ativa nos projetos da filial e nunca havia deixado de participar das reuniões sobre o Ensino Reflexivo. P1 sempre teve uma posição crítica com relação ao projeto, não propriamente de resistência, mas sim de questionamento acerca de sua validade dentro da estrutura administrativa da escola. Por essa razão, procurei agendar nossa conversa.

Os outros três professores lecionavam na escola havia aproximadamente seis anos e também haviam presenciado os primeiros passos do projeto. Além de trabalhar na instituição com alunos de diversos níveis de proficiência e idades, P2 tinha alunos particulares. No momento da coleta do corpus, havia acabado de entrar em um programa de pós-graduação em Lingüística Aplicada. Ela se mostrava muito interessada em novas abordagens pedagógicas e, de certa forma, eufórica com relação ao projeto e às inovações que ele parecia trazer. Consequentemente, eu imaginava que poderia obter uma visão mais otimista a partir dessa professora.

O único professor da pesquisa também tinha alunos particulares e, semelhante a P2 e P4, trabalhava com idades e níveis de proficiência diversos, chegando aos níveis considerados intermediários-avançados. P3 não tinha formação acadêmica em Letras, mas possuía diploma da Universidade de Cambridge e havia cursado complementação pedagógica. Eu o conhecia desde o treinamento de professores, pois havíamos ficado no mesmo grupo, portanto tínhamos muita abertura um com o outro para expor nossa opinião. 
P4, por sua vez, tinha formação na área de psicologia, e atuava como coordenadora pedagógica da área de inglês em uma escola da rede de ensino particular de São Paulo. P4 se destacava junto ao corpo docente pela habilidade que tinha em lidar com adolescentes e sempre contribuía de maneira clara durante as sessões de Ensino Reflexivo.

Essas pequenas peculiaridades de cada um dos informantes, bem como a visão de como o projeto era aceito por cada um deles (proveniente das observações da pesquisadora), auxiliaram na escolha desses sujeitos para colaboradores de nossa pesquisa.

\subsection{A gerência da filial focal}

Tanto a gerente da filial como a gerente assistente contribuíram para esta pesquisa. Ambas já haviam ministrado aulas na instituição, porém em diferentes filiais. Também haviam presenciado o início do projeto e tinham exercido seus cargos em outras escolas da rede antes de chegar à filial em questão. A gerente assistente possuía formação acadêmica em Letras, enquanto a gerente, em Marketing.

\subsection{A pesquisadora}

O fato de a pesquisadora atuar como treinadora do projeto causou um certo estranhamento em alguns professores na época das entrevistas, pois alguns deles se mostravam receosos quanto ao tipo de informação que poderiam estar fornecendo. Além disso, pareciam ficar preocupados com o tipo de linguagem a ser usado. Esse temor inicial foi sendo dissipado à medida que os professores percebiam que a pesquisadora os questionava como tal, e não na função adicional que exercia no momento da pesquisa (a de professora-multiplicadora).

\section{Conclusão}

Neste capítulo, procuramos mostrar como ocorreu a implantação do projeto de Ensino Reflexivo na instituição que é foco da dissertação. Visto como uma 
experiência inovadora, o projeto pretendia mudar concepções de ensino enraizadas, principalmente, no corpo docente de uma escola de línguas conceituada.

Apesar de ter começado com reuniões opcionais, aos poucos o Ensino Reflexivo foi instituído como obrigatório e a necessidade de engajamento era vista como vital para o futuro dos docentes envolvidos. O momento do projeto focalizado em nossa pesquisa é aquele em que o Ciclo de Aprendizagem Experimental foi adotado como modelo de aula. Esse modelo parecia se estabelecer, aos olhos da instituição, como um novo paradigma que auxiliaria o aluno a perceber seu progresso na aquisição do inglês. O aluno seria capaz de construir seu conhecimento a partir de sua própria experiência na língua materna.

Para ser bem sucedido, o projeto precisava contar com uma estrutura que envolvesse todos os funcionários (gerentes, departamento acadêmico, professores, etc...), pois a instituição procurava homogeneizar o discurso em todas as filiais. Para tanto, contava com o apoio dos professores-multiplicadores, em especial, pois eles eram o elo de ligação entre a gerência e os docentes.

Os sujeitos participantes desta pesquisa estiveram presentes nas reuniões e conviveram com o projeto desde seu início, assim como a pesquisadora. Eles faziam parte do grupo do qual sairia a construção do "novo" conhecimento que era gerado. As reuniões, por sua vez, eram o local em que os questionamentos surgiam, e como veremos no Capítulo 3 (página 56), serviram também como ponto de partida para o controle do discurso exercido pela instituição, juntamente com os planos de ação e as pesquisas de satisfação.

O treinamento em serviço de ER do instituto de línguas focal almejava ser capaz de formar um professor crítico. Paralelamente, a gerência de Qualidade Total foi implantada, desenvolvendo-se um sistema administrativo cada vez mais centrado no atendimento das necessidades dos clientes. Assim, os pressupostos do neoliberalismo permeiam todo o projeto, desde a preocupação com o engajamento e 
treinamento dos funcionários até o direcionamento para a solução de problemas. Por essa razão dedicamos nosso próximo capítulo ao discurso neoliberal e seus efeitos na escola, especificamente no instituto de línguas estudado. 


\section{CAPÍTULO 2:}

\section{O Discurso Neoliberal no Instituto de Línguas}

Durante nossa pesquisa, verificamos que o discurso neoliberal de Qualidade Total permeia toda a construção do projeto de Ensino Reflexivo, pois a escola é vista como uma empresa em busca de ideais de qualidade que the proporcionariam uma melhoria nos serviços e conseqüente aumento no número de alunos. Face a essa constatação, decidimos aprofundar nossa reflexão tecendo algumas considerações sobre o programa de Qualidade Total e como ele está inserido no contexto educacional mais amplo, além de relacioná-lo ao contexto estudado.

Assim, nosso intuito neste capítulo é discutir a relação entre o pensamento neoliberal de Qualidade Total e o programa de Ensino Reflexivo da instituição de ensino estudada. Primeiramente, faremos uma exposição de algumas idéias neoliberais e como elas se encaixam no campo educacional. Posteriormente, verificaremos como esses conceitos se refletem no instituto de línguas através da fala da gerência. Para tanto, estaremos discutindo a mudança dos papéis dos sujeitos envolvidos, a necessidade de engajamento, a aula com qualidade, a satisfação do cliente e a constante avaliação do processo.

Os enunciados produzidos pela gerência serão analisados ainda sob a perspectiva da metodologia etnográfica, já que nossa intenção é produzir um panorama dos elementos ligados ao projeto do Ensino Reflexivo. A materialidade lingüística dos enunciados será explorada nos Capítulos 3 e 4.

\section{O Projeto Neoliberal}

Apesar de nossa pesquisa não ter como objetivo analisar o sistema educacional brasileiro e sim uma instituição privada de ensino de língua inglesa como língua estrangeira, o panorama que rege a introdução do pensamento neoliberal de Qualidade Total pode ser reconhecido na implementação do projeto de Ensino Reflexivo na instituição estudada. Um exemplo é a preocupação da instituição com a 
diminuição do números de alunos e com a satisfação dos mesmos em relação à escola. Para discutir como essa visão está ligada ao contexto educacional geral, partiremos de algumas características que se aplicam ao discurso neoliberal, de acordo com Amarante (1998), Gentili \& Silva (1994/2001) e Marcello (2000), conforme a descrição a seguir.

A gerência de Qualidade Total foi desenvolvida no Japão após a $2^{\mathrm{a}}$ Guerra Mundial, como fruto da influência das idéias econômicas americanas. No Brasil os anos 80 foram seu marco, já que muitas indústrias começaram a ter dificuldades com o crescimento da concorrência internacional aos produtos brasileiros. Essa situação foi influenciada, na década de 90, pelo governo Collor, que facilitou as importações de produtos de origem estrangeira.

Segundo Silva (op. cit.), a estratégia neoliberal em busca da construção de um discurso hegemônico inclui não só o campo educacional, como focamos nesta pesquisa, mas as esferas social, política e pessoal. Essa estratégia vem sendo colocada em prática através de um projeto de cunho liberal que tenta visualizar as esferas acima sem que seja possível seu afastamento do arranjo capitalista.

O projeto neoliberal baseia-se na defesa do Estado Mínimo. O Estado é considerado burocrático e ineficiente, enquanto a livre iniciativa redefiniria conceitos e noções como as de igualdade e justiça, que passam a ser noções de "produtividade, eficiência, qualidade, colocadas como condição de acesso a uma suposta modernidade" (Silva, op. cit.:14, grifos do original). Sem a modernização das esferas sociais e políticas não seria possível chegar ao patamar de excelência necessário no mundo globalizado. Por conseguinte, qualquer opinião contrária a esses fundamentos seria automaticamente silenciada.

Amarante (op. cit.:54), por sua vez, salienta que o Estado Neoliberal, ao se apoiar nas demandas do mundo dos negócios, acaba por revelar uma contradição interna em seu projeto. Isto porque, apesar de ser contrário ao protecionismo (ao favorecer 
a livre iniciativa), ele apenas dispersa essas práticas, dirigindo-as a outros projetos que se baseiam em interesses comerciais. Além disso, Amarante (op. cit.) ressalta que a busca da autonomia individual propiciadora da escolha pública social só poderia ser atingida dentro de um "contexto político-cultural altamente estável, maduro, racional e consensual, que, certamente, não se revela no cotidiano da realidade brasileira".

Gentili (2001) também menciona algumas características do discurso da Qualidade Total (doravante QT) no mundo dos negócios. A primeira é que a qualidade existe como estratégia competitiva num mercado cada vez mais diversificado e diferenciado, apesar de o discurso empresarial tentar colocá-la como uma maneira de melhorar a qualidade de vida do consumidor. Ou seja, o objetivo principal dessa estratégia não é melhorar a vida do consumidor, mas conquistar um mercado maior dentro do contexto competitivo em que vivemos.

Em segundo lugar, os aspectos qualidade-produtividade-rentabilidade não podem ser analisados separadamente. Para a QT, a qualidade só interessa se vier acompanhada de lucro, e a produtividade só faz com que esse lucro possa aumentar.

Além disso, a busca da qualidade supõe uma organização particular do processo produtivo, que se relaciona a como é feito o controle da qualidade e da disciplina. A organização do processo produtivo sugere que o engajamento de todos os setores de uma empresa é fundamental para que a qualidade exista. Da mesma maneira, sem o controle e a disciplina, esses setores poderiam se dispersar, o que implicaria diminuição da qualidade e, como conseqüência, do lucro.

Finalmente, a qualidade é vista como mensurável, além de ter um custo, ou seja, ela só pode ser considerada boa quando produz resultados. Essa afirmação nos remete à segunda característica, mas salienta a necessidade da medição dos resultados para que fique comprovado que a qualidade surtiu o efeito desejado. 


\subsection{Qualidade Total e Educação}

O discurso da qualidade na educação começou a ser desenvolvido na América Latina nos anos 80, fruto do discurso de democratização do ensino (Gentili, 2001). Esse tipo de discurso esteve presente nas nações que, como foi o caso do Brasil, passaram de governos autoritários para os democráticos, sem que essa transição pudesse ser considerada um sucesso, uma vez que houve uma distorção quanto à democratização dos direitos da cidadania e o espaço público acabou por evidenciarse. Ou seja, apesar de apresentar um avanço em relação ao tipo de governo, a democratização não conseguiu pôr a livre iniciativa como fator gerador de progresso, havendo um controle ainda grande e burocrático do Estado em vários setores como a previdência, a saúde e a educação, entre outros, o que seria visto como negativo pela perspectiva neoliberal.

Muitos países da América Latina caminharam da ditadura militar para a abertura, mas essa mudança teria sido mais de ordem lingüística que ideológica, pois a constituição de muitos governos continuou quase a mesma. O Brasil foi um desses casos, e seu projeto neoliberal direcionado para a educação deve ser visto como parte de um processo mundial. Seguindo o exemplo de Estados Unidos e Inglaterra, o país aderiu à globalização e a todos os seus sentidos, como o incentivo à produtividade e à transformação do cidadão em consumidor. Assim, esse discurso é construído de maneira a excluir outras realidades, ou seja, o discurso liberal fixaria maneiras de pensar e acabaria por fixar-nos como sujeitos sociais, dizendo-nos o que deve ou não ser feito.

Esse tipo de crítica também poderia ser aplicado à educação, já que as mesmas pessoas que defendiam o "tecnicismo educacional" (Silva, 2001:17) nos anos anteriores, como Cosete Ramos, defendem agora a filosofia da qualidade total. Durante a ditadura militar, Ramos elaborou um conjunto de livretos que defendiam a instrução como conjunto de técnicas (seu nome era "Engenharia da Instrução"), enquanto hoje difunde a cartilha do Ministério da Educação baseada em preceitos neoliberais. Silva (op. cit.:17, grifos nossos) salienta que: 
(...) também não será por acaso que, embora alguns desse atores voltem à cena na mesma posição, outros atores se apresentem agora no campo oposto, engrossando aquela considerável legião de intelectuais e cientistas sociais de esquerda que se transformaram em neoconversos da livre iniciativa e da "modernização" (...) que se juntam a emergentes ideólogos educacionais de direita, a tecnólogos educacionais reciclados e a participantes do golpe militar travestidos de neoliberais para propagar o novo credo educacional. Entre essas condições transformadas, há uma nova economia do afeto e do sentimento, uma forma nova e muito mais sutil de envolvimento e engajamento dos sujeitos e das consciências que a crítica tradicional, baseada em noções racionalistas e instrumentais de poder e interesse, pode ser incapaz de perceber, captar, penetrar e contestar.

De acordo com Silva (op. cit.), as pessoas que estavam à frente da educação na época da ditadura hoje lideram o movimento em busca da qualidade, pois se adaptaram aos novos conceitos, muitas vezes se juntando a outras que anteriormente faziam parte da oposição. Ao se adaptarem, tornaram-se mais eficazes, pois essa maneira "sutil" de engajar "sujeitos" e "consciências" funciona como forma de obtenção e controle do discurso e do poder e, consequentemente, como meio para a manutenção da influência.

No campo educacional, a Qualidade Total redefine a educação em termos de mercado. A educação, que em Althusser (1985) já é vista como aparelho regulador e de controle social, passa a ser mais voltada para o mercado de trabalho. Currículos começam a ser adaptados para suprir as necessidades das empresas e indústrias, ao mesmo tempo que os pressupostos neoliberais são incutidos na sociedade, que passa não só a aceitar essa nova perspectiva mas também a reforçá-la, acreditando que esta seja a única alternativa válida numa sociedade moderna. Um exemplo disso está na criação de um número cada vez maior de cursos universitários que propõem carreiras específicas para cada área de atuação. Assim, o que antes seria um curso de administração passa a ter especializações, ou ênfases em comércio exterior, administração hospitalar, etc..., visando a um mercado cada vez mais específico. 
Gentili (2001), em sua crítica ao discurso da QT, coloca em pauta três princípios básicos do pensamento neoliberal no campo educacional. Em primeiro lugar, qualquer tipo de interferência pública é visto como prejudicial, por mostrar-se sempre ineficiente, corrupto e burocratizante, atribuindo-se assim ao Estado toda a culpa pelos males econômicos e sociais, como já foi ressaltado acima. Ao se insistir nos aspectos negativos dessa interferência, valoriza-se o pensamento capitalista, pois ele reforça que é o mercado que deve regular a produção.

Em segundo lugar, o privilégio de estar entre os vencedores deve ser visto como necessário e altamente desejável, já que o capitalismo e a livre iniciativa são donos de virtudes inerentes. Por exemplo, em nosso contexto de ensino de línguas estrangeiras, o vencedor é aquele indivíduo que consegue fazer um curso que produza os resultados esperados, ou seja, que ele consegue falar numa segunda língua com maior proficiência possível e em menos tempo. Ao menos esse é o sentido produzido por grande parte das propagandas de institutos de língua (Carmagnani, 2001) que são influenciadas pelo discurso econômico e pela ideologia da globalização, contexto em que o conhecimento da língua inglesa se torna condição essencial para o sucesso em uma profissão.

Por fim, as pessoas menos favorecidas deveriam ser consideradas pois pertenceriam a uma espécie de subclasse social e seriam incapazes de articular uma saída para sua situação. A QT teria, então, um aspecto redentor ao ajudar essa classe a ser melhor. Na realidade, o que o autor salienta é que para a manutenção desse sistema liberal/ econômico é necessário que se garanta essa dualização entre os privilegiados e os não privilegiados. Ou seja, esse argumento não teria a menor validade pois o interesse maior é que essa "subclasse" exista para a manutenção do status quo.

O programa "Escola de Qualidade Total" desenvolvido no Brasil por Cosete Ramos leva em conta as características centrais dos programas empresariais e tem como proposta um pacto de qualidade que deve ser estabelecido por alunos, professores, 
dirigentes, enfim, pela sociedade como um todo. Esse programa procura repensar as estruturas escolares e é baseado nos ensinamentos de W. Edwards Deming e seu "Método de 14 Pontos"33 (apud Gentili 2001:144).

Na perspectiva de Deming (op. cit.), as estratégias que induzem à participação na escola provocam uma mudança nas práticas dominantes. Essa mudança seria provocada de baixo para cima e seria baseada na vontade dos professores, estudantes e diretores que assumiriam um "pacto de qualidade". Essa idéia de "pacto de qualidade" nos parece ser por demais idealista, a começar pela noção de que as mudanças acontecem de baixo para cima. Como se sabe, o modelo da QT foi imposto aos professores do sistema de ensino tradicional da mesma maneira que o aumento da produtividade é imposto aos trabalhadores de uma empresa, ao contrário de um "pacto" que teria como princípio a vontade dos trabalhadores.

\section{A Qualidade Total no instituto de línguas}

$\mathrm{Na}$ instituição locus da pesquisa notamos que o discurso da administração (aqui representado pela gerência da filial) e dos professores (como veremos nos Capítulos 3 e 4) é constituído pela ideologia neoliberal. Amarante (1998:215) já aponta esse fato ao discutir as estratégias usadas na busca pela qualidade no contexto da escola. Ao procurar garantir que o instituto de línguas se mantenha competitivo no mercado, a escola favorece a perspectiva de que o conhecimento obtido poderá ser útil para seu aluno/ cliente.

Mesmo a abordagem usada em aulas de língua estrangeira hoje em dia, a comunicativa, pode ser vista como uma maneira de atrair o interesse do mercado para a função instrumental do aprendizado. Seja na discussão sobre a avaliação de aprendizado proposta por Amarante (op. cit.), seja no novo modelo de aula proposto pelos PMs da instituição observada (o Ciclo Experimental de Aprendizagem), há de

\footnotetext{
${ }^{3}$ 1. Filosofia da qualidade; 2. Constância de propósitos; 3. Trabalho escolar de alta qualidade como produto de uma escola de qualidade; 3. Avaliação do processo; 4. Transações de longo prazo; 5. Melhoria constante; 6. Treinamento em serviço; 7. Liderança; 8. Distanciamento do medo; 9. Eliminação de barreiras; 10. Comunicação produtiva; 11. Abandono de quotas numéricas; 12. Orgulho na execução; 13. Educação e aperfeiçoamento; 14. Ação para transformação.
} 
se notar a preocupação em deixar claro que tudo que o aluno/ cliente vier a aprender servirá, de alguma maneira, no seu dia-a-dia.

Discutiremos, a seguir, algumas características do projeto de ER que apontam para a influência do discurso de QT. Essas características também são encontradas no discurso empresarial, conforme Amarante (1998: 63), sob a forma de princípios que embasam o discurso neoliberal de $\mathrm{QT}^{4}$. Ou seja, itens como a mudança de papéis dos sujeitos envolvidos, a necessidade de engajamento, a aula com qualidade, a satisfação do cliente e a constante avaliação e controle do processo também fazem parte do universo empresarial, mas estão adaptados ao contexto de nossa pesquisa.

\subsection{A mudança dos papéis dos sujeitos envolvidos}

A perspectiva da QT sugere que existem papéis na estrutura organizacional de uma empresa. Esses papéis estão ligados à importância que cada funcionário teria para que os objetivos da instituição fossem atingidos. A correta delegação de responsabilidades (princípio 7) poderia garantir que a qualidade fosse atingida, já que todos estariam trabalhando por um objetivo em comum.

Ao discutir essa noção de papéis, deparamos com dois sentidos. O primeiro está relacionado ao papel do professor e do aluno em sala de aula e sua ligação com a educação, que é também mencionado no ER. O segundo, mais específico, nos remete às posições ocupadas pelos sujeitos envolvidos no projeto de ER da instituição, tanto antes como depois da implantação do mesmo. Vejamos dois momentos da entrevista com a gerente da filial da escola estudada em que ela menciona esses dois papéis ${ }^{5}$ :

\footnotetext{
4 1. Satisfação total dos clientes; 2. Desenvolvimento de recursos humanos; 3. Gerência participativa; 4. Constância de propósitos; 5. Aperfeiçoamento contínuo; 6. Gerência de processos; 7. Delegação de responsabilidades; 8. Garantia de qualidade; 9. Disseminação de informações e 10. Não-aceitação de erros.

${ }^{5}$ Gostaríamos de esclarecer a metodologia usada na transcrição. Os professores-multiplicadores são os PMs (1 ou 2, dependendo do multiplicador). Os professores são enumerados por ordem de fala (P1, P2, etc...), a gerente da filial é G, a assistente A, o gerente acadêmico GA, a entrevistadora E. As pausas são marcadas com a barra (/), e as maiúsculas sugerem o aumento do tom de voz do falante, com exceção do "eu" em inglês, "I". Uma fala sobreposta é indicada pelo uso de itálicos, enquanto os grifos são nossos.
} 


\section{Excerto 1:}

E: a primeira coisa que eu gostaria de saber é como você explicaria o que é o reflective teaching

G: (...) e eu acompanhei desde o início a introdução do projeto de reflexão ahh/ na XXX el ah eu posso dar ah/ o que é proposto pelo projeto e o meu entender disso ah/ na sala de aula/l o que o projeto propõe na verdade é que o ahh/ o processo de reflexão tendel ele foi introduzido prá criar uma mudançal uma mudança de visão ah/ de vários papéis/ o papell o nosso papel em/ nol na questão de educaçãol o papel do professor em sala de aulal e o papel do alunol então nesse sentido eu penso que o projeto ahh/ espera que que o ahh/ o/ a o a energia que ocorre na sala de aula/ é uma forma diferente de ver esse trabalho/ ele não é uma metodologia/ ele não é uma/ uma maneira de abordar exercícios de forma diferente/ mas ele propõe toda uma mudança ahh/ no no/ no relacionamento/ no papel do professor e do aluno em sala de aula/ isso é meio abstrato/ né/ mas um professor reflexivo por exemplol é aquele que tá sempre questionando os porquês que as coisas acontecem/ o porquê que ELE faz as coisas daquela forma e o porquê que os alunos fazem as coisas daquela formal então ele tá sempre questionandol ele tá propriamente não só questionando/ mas agindo em cima disso/ então ele ahh/ o que o projeto propõe é que/ se as intervenções que/ ah/ ah/ conduzam o aluno ao aprendizado sejam baseadas NA observação// a o/ professor intervém/ observal e atua novamentel faz outra intervenção

Nesse excerto, podemos notar que a gerente menciona o papel da escola, do professor e do aluno na educação como um todo ("o nosso papel em/ no/ na questão de educação/ o papel do professor em sala de aula/ e o papel do aluno"). Nesse caso, a transformação da visão sobre a educação ocorreria graças ao ER e às profundas mudanças ocasionadas no modo de intervir na realidade ("tá sempre questionando os porquês"). Devemos lembrar que um professor reflexivo deveria estar sempre usando a sua experiência como ponto de partida para um olhar mais crítico sobre sua prática.

Além disso, podemos perceber como esse tipo de reflexão está de acordo com a abordagem usada em sala de aula no momento da pesquisa, a do aprendizado experimental. Segundo essa abordagem, a aula partiria de uma experiência concreta (dos alunos) que levaria a uma observação reflexiva por parte do professor para que ele pudesse intervir em seu plano de aula e fazer ajustes que levariam a uma potencialização do aprendizado. É isso que a gerente pode estar querendo dizer 
com "estar questionando" e com "as intervenções que (...) conduzam o aluno ao aprendizado sejam baseadas na observação", pois essa intervenção equivaleria ao que ocorre no momento da observação reflexiva $(R O)$ e da conceitualização abstrata (AC), momento seguinte do ciclo no qual se dá a racionalização dos problemas, assim como a descoberta das razões das situações críticas enfrentadas em aula. Nesse aspecto, o enunciado da gerente também nos remete a uma visão sóciointeracionista de aprendizagem, que tem como pressuposto o aprendizado como parte de um contexto sócio-histórico-cultural em que os processos cognitivos são um resultado da interação social (Lightbown \& Spada, 1993).

Nesse excerto, vemos que a gerente traça então, um paralelo entre o que deveria ocorrer em sala de aula e o que é esperado do professor no ER. Mas a mudança na postura da escola, do professor e do aluno nos remete a um outro nível de relações, aquele pressuposto pela relação produto-consumidor. O "nosso papel (...) na questão de educação" do enunciado da gerente, na minha visão de observadora, pode ser relido como o papel da escola como a empresa que vende um produto e do aluno, consumidor final. Sob essa perspectiva, os papéis a serem desempenhados seriam os de funcionários "com qualidade" que se esforçam para ter um produto com mais qualidade. Por isso, em outro momento da mesma entrevista, a gerente faz um comentário sobre um outro papel, dessa vez relativo à participação dos membros da instituição no projeto:

\section{Excerto 2:}

E: e como você acha que isso [a mudança de paradigmas provocada pelo projeto] foi visto pelos ahh/ gerentes/ e pelos professores

G: no começo/ como toda coisa nova/ e MUITO abstrata/ foi difícil (...) nós passamos meio que tentando entender o projeto ah/ como todo mundo/ a estrutura/ ah/ em termos de condução de gerenciamento e administração do projeto foi uma estrutura que foi proposta completamente horizontall então não existia PAPÉIS a serem desempenhados/ a não ser os das multiplicadoras/ el então isso foi uma coisa que foi levada muito a sériol então todo mundo num mesmo barco(...) 
Essa estrutura aparentemente "horizontal" mencionada pela gerente nos leva ao aparente processo de descentralização de poderes que aconteceu no início do projeto. O enunciado acima sugere o tipo de estrutura mencionado por Ramos, em que a qualidade seria construída de baixo para cima (apud Gentili, 2001:145). A partir da vontade de cada professor para provocar a mudança e avaliar seu próprio trabalho, uma das barreiras da qualidade seria eliminada.

Qualquer tipo de centralização é considerado pela gerência de QT como um obstáculo a ser transposto. Essa descentralização ("não existia PAPÉIS a serem desempenhados") nos leva a uma idéia de democratização de poderes, um quase apagamento da hierarquia da escola, como se não houvesse dentro dela nenhum mecanismo de controle ou regulação do discurso, o que na realidade seria impossível, já que toda a estrutura do Ensino Reflexivo colaborava para a manutenção e distribuição dos poderes fixados anteriormente ao projeto.

O que se quer sugerir é que as contradições e os conflitos existem e não é possível que sejam eliminados por uma suposta supressão da hierarquia. A gerência da filial exerce um novo papel, mas continua a existir como tal e a pressionar o grupo de professores para garantir a qualidade. Os professores, por sua vez, começam a perceber que a satisfação do cliente nem sempre condiz com sua visão (de professor) do que é uma aula com qualidade. Qualquer procedimento valeria como adequado contanto que o aluno demonstrasse que gostava do professor e das aulas nos questionários, e não seria prudente assumir a responsabilidade de todo o processo. A QT aparentemente abre espaço para a criatividade, invertendo o processo produtivo: eu me baseio no produto final para descobrir como posso chegar até ele. Porém, existe a dificuldade em precisar qual seria o final do processo de ensino de línguas.

Da maneira como esse modelo deveria funcionar, os gerentes seriam uma espécie de agentes de mudança. A partir da implementação do ER, o papel da gerência e do departamento acadêmico havia realmente mudado, mas não desaparecido, como 
esse enunciado nos faz crer. A gerência, que estava mais ligada ao aspecto administrativo da condução da escola, deveria, a partir de então, estar mais envolvida com o processo de treinamento em serviço dos professores e seria responsável pelo total engajamento dos mesmos (uma das razões pelas quais os professores tentavam estar sempre presentes nas reuniões). Já os membros do departamento acadêmico, que faziam parte da estrutura pedagógica da instituição, seriam então ajudados pelos multiplicadores em cada uma das filiais.

Os PMs seriam, como salientado nesse trecho ("a não ser os (papéis) das multiplicadoras/ e/ então isso foi uma coisa que foi levada muito à sério"), peças importantes e novas na estrutura do projeto pois dividiriam com o departamento acadêmico a responsabilidade pela disseminação de idéias (como no princípio 9 do discurso neoliberal), além de auxiliarem os professores em seu processo de aperfeiçoamento (princípio 5). Eles resolveriam uma questão prática: o número de membros do departamento acadêmico seria insuficiente para cumprir a tarefa de apresentar duas reuniões por mês em cada filial além do trabalho de treinamento dos novos professores. A promoção de novas pessoas para os cargos do departamento acadêmico também seria inviável, pois acarretaria mais custos. Mais que isso, os PMs auxiliariam na disseminação de idéias, pois sendo pessoas vistas como iguais pelos outros professores, suas orientações poderiam ser melhor aceitas. Haveria a impressão da construção do conhecimento por parte das pessoas presentes nas reuniões, já que era salientado que estas reuniões deveriam sempre seguir as necessidades de cada filial. Isto nos remete a Foucault (1979/2000) e sua teoria da circulação do poder e do saber.

Foucault (op.cit.) sustenta que existem "regimes de verdade", os quais são uma condição de formação do sistema capitalista. "Verdade", nesse contexto, diz respeito ao "conjunto de procedimentos regulados para a produção, a lei, a repartição, a circulação e o funcionamento dos enunciados" (op.cit:14). Esses procedimentos, por sua vez, estão ligados aos sistemas de poder que são tanto produzidos como apoiados por essa verdade. Nesse sentido, o ER poderia ser considerado um 
elemento de um regime de verdade, pois produz enunciados que acabam por reforçar a estrutura da instituição e guiar a produção de sentidos.

Assim, os objetivos impostos pelos multiplicadores acabavam aparentemente aceitos pelos professores através da estratégia da reflexão. Os temas propostos pelos multiplicadores eram transformados em tópicos de discussão e posteriormente direcionados para os objetivos reais da reunião. Ao final de cada sessão, todo saber produzido seria levado às camadas mais poderosas da instituição, inclusive as possíveis críticas, para que pudessem ser formulados novos enunciados que seriam mais tarde apoiados pelos próprios professores.

Por exemplo, digamos que o intuito de uma reunião fosse apresentar uma abordagem de aula e seus pontos positivos. Não era simplesmente feita uma apresentação sobre como deveria ser uma aula já com todos os seus pontos positivos. Ao invés disso, um modelo já pronto e subdividido em etapas era apresentado para os professores, que deveriam colocá-lo em uma ordem racional de acontecimentos e discutir seus pontos fortes e fracos. Intencionalmente os pontos positivos dessa aula eram reforçados pela citação de um autor ou teoria e os professores eram solicitados a dar sua avaliação sobre as reuniões. Essa avaliação seria considerada para o encontro seguinte. Ao ser dada essa abertura para os professores, produziu-se um sentido de que eles também tinham participação na produção de saberes ligados ao projeto.

Assim, podemos sugerir que os sentidos pelo funcionamento do projeto na instituição também foram impostos, e não produzidos a partir dos professores, ou "de baixo para cima" como na concepção de Ramos (apud Gentili, 2001). Como veremos ao discutir o engajamento dos funcionários, a maneira como o projeto foi colocado fez que os funcionários tivessem a impressão de que eles eram as células da mudança, e não a instituição, o que remete ao funcionamento dos "regimes de verdade" conforme Foucault. 


\subsection{A necessidade de engajamento}

Como já mencionamos ao discutir o microcosmo de nossa pesquisa, o projeto foi inserido no instituto de línguas ao mesmo tempo que a gerência de QT foi implantada. Um dos pontos mencionados na perspectiva de Ramos (op.cit.: 143) é que a transformação só acontece se existir um "Pacto para a Qualidade estabelecido entre alunos, professores, dirigentes técnicos, pessoal administrativo do setor educacional, padres e a sociedade como um todo". Em outras palavras, o engajamento de toda a instituição seria visto como um requisito para que a escola alcançasse seus objetivos de eficiência.

E como a instituição havia se organizado para que esse pacto fosse estabelecido? Num primeiro momento, funcionários de todos os departamentos foram convidados a fazer um curso ministrado por um consultor externo que objetivava uma melhoria da comunicação entre os setores. Tagata (2000) descreve alguns dos conceitos trabalhados pelo curso ministrado aos funcionários da instituição, o qual teria auxiliado na aplicação desse modelo gerencial apresentado como mais participativo e motivador. Entre esses conceitos estão a orientação para o cliente; a qualidade em primeiro lugar; a ação orientada por prioridades, fatos e dados; a qualidade assegurada pelo controle do processo e, em especial, a noção do cliente interno, a pessoa que também presta serviço dentro da instituição e que deve estar sempre motivada para que a empresa chegue aos patamares de qualidade desejados. Os que mais nos chamam a atenção são a preocupação com a ação orientada por prioridades, fatos e dados e a noção do cliente interno.

Durante os primeiros anos do projeto, não era raro que os professores fossem requisitados a lembrar de fatos ou problemas que os incomodavam, fosse através de gráficos que esboçassem seu desenvolvimento ou através dos planos de ação em que deveria constar com objetividade o nível de proficiência do grupo pesquisado, como seria feito o controle dos planos de ação e como seriam medidos os resultados. Os itens a ser investigados não deveriam ser muito complexos, pois isso dificultaria o controle. Por exemplo, não era possível estudar o tema disciplina 
porque ele seria muito abrangente. O professor poderia pesquisar, então, como diminuir o uso do português em aula (já que isso poderia ser visto como fator de indisciplina). Desse modo, ficaria mais fácil constatar se os alunos estavam ou não recorrendo à língua materna através da visita de outro professor ou da gravação de uma aula em vídeo/ áudio.

Já o "cliente interno"6 era sempre lembrado, em especial nas entrevistas com os professores, pois muitos reclamavam que não havia espaço na instituição para que o cliente interno ficasse satisfeito, todos os esforços estavam direcionados para o cliente-consumidor e suas necessidades.

De certa maneira, o curso também estava aliado ao desejo de descentralização dos poderes. Uma vez que os funcionários (gerentes, diretores administrativos, professores, funcionários de secretaria) se vissem como parte de uma mesma instituição que deveria trabalhar unida para o progresso, as relações de poder dentro da escola seriam de certa forma democratizadas, o que produziria um sentimento de cumplicidade entre esses indivíduos e, conseqüentemente, um maior engajamento.

Uma outra maneira de estabelecer esse "Pacto de Qualidade" no instituto foi a apresentação do projeto de ER para os professores. O projeto não era obrigatório a princípio, apenas os professores do nível intermediário haviam sido convidados a participar das sessões. Contudo, o discurso vigente era de que aqueles que se envolvessem no Ensino Reflexivo teriam um ganho pedagógico/ pessoal valioso, pois estariam em contato com as mais novas tendências educacionais. Com isso, a instituição foi promovendo o interesse por parte dos professores, as reuniões passaram a ser abertas para os professores de todos os estágios até que se tornaram obrigatórias, funcionando como um item de controle de produção.

Ao ser questionada, em outro momento da mesma entrevista, sobre como o projeto havia sido colocado para os professores, a gerente da filial diz:

\footnotetext{
${ }^{6}$ Os funcionários de uma empresa em relação a outros funcionários, conforme a gerência de Qualidade Total.
} 


\title{
Excerto 3:
}

\begin{abstract}
G: nosso entendimento do projetol el el era um barco/ era uma viagem/ então ahh/ a pessoa tem que querer vir junto nessa viagem/ né/ porque a gente colocou em questionamento as CRENÇAS dol dos/ das pessoas/ eu digo pessoas porque eu penso no professor como um indivíduo ali/ se questionando/ então isso tinha que ser um processo meio que voluntáriol do professorl não totalmente porque a empresa queria mudar/ então todo mundo ia ter que eventualmente embarcar/ vamos dizer no/ no projeto/ mas no começo tinha que ser uma coisa que o professor se interessasse em fazer/ porque isso ia mexer muito com/ como mexeu com a gentel com um ahh/ conceitos/ sobre o papel do professorl sobre o ensinol o aprendizado/ muito fundamentais
\end{abstract}

Nesse excerto podemos notar uma visão romântica do projeto, segundo a qual a reflexão levaria a um maior conhecimento das "crenças" de cada sujeito envolvido, como também defende o discurso de QT, que diz que a razão para qualquer mudança deve estar na iniciativa individual. Vemos também a tentativa de colocar o professor como o agente da mudança e não como sujeito influenciado pela instituição e constituído por diversas formações discursivas (Brandão:1991; Orlandi:1999). Até mesmo o vocabulário usado nos remete ao mundo dos negócios: ao invés de "escola", a gerente usa a palavra "empresa".

De certa maneira, esse deslocamento de sentidos faz que a proposta de aumentar a produtividade e o número de alunos seja vista como normal e desejável, sem que outros fatores sejam considerados, no caso o aluno (ou seria o cliente?). 0 aprendizado de uma segunda língua e todas as dificuldades pelas quais o aluno passa para ser bem-sucedido são colocados em segundo plano. O verdadeiro produto desejável do ER no excerto estudado não é a mudança de valores e crenças sobre a prática de ensino, mas sim um número maior de alunos, como a gerente acaba por explicitar mais adiante: 


\title{
Excerto 4:
}

\begin{abstract}
G: olha o projeto foi introduzido prá aumentar a retenção de alunol a satisfação e a retenção/ né/ e/ tem muitas variáveis aí/ que aí é uma outra área que eu poderia ficar discutindo aqui outras horas/ com você e não vem ao caso/ então na verdade a medida disso é muito concreta/ ah/ a gente tem duas formas de medir isso/ pesquisa de satisfação dos alunos el a/ os nossos números de retenção [a entrevistadora concorda]/ então queda/ o drop-out durante o semestrel taxas de rematrícula e tudo mais/ então nesses sentidos os nossos métodos são bastante concretos
\end{abstract}

Fica claro que o ensino passa a ser avaliado não como uma "viagem ao conhecimento", mas sim como meio de aumentar a retenção de alunos e as matrículas. Da maneira colocada, a satisfação nem parece ser tão desejável quanto a retenção ("o projeto foi introduzido prá aumentar a retenção de aluno/ a satisfação e a retenção"), pois não adiantaria que os alunos estivessem satisfeitos se isso não ocasionasse a rematrícula. Apesar de a própria gerente se colocar no lugar de educadora ao tentar avaliar suas "crenças" (já que ela também havia trabalhado como professora), a voz da instituição que procura resultados "concretos" demonstra que o conflito existe e permeia o projeto.

Apesar de as pesquisas de satisfação serem um item de controle, as possíveis razões para as desistências ou números menores de matrículas passam a ser analisadas como uma falha do ER e das pessoas envolvidas na filial em questão. Os métodos de medição de resultados são vistos como concretos, isto é, científicos, portanto incontestáveis. Nesse caso, um mau resultado seria considerado pela instituição como uma falha do grupo, do engajamento dos indivíduos da filial e não dos procedimentos estabelecidos pela instituição para conduzir o projeto.

Ao mesmo tempo, esse apelo ao engajamento profissional promovido pelo projeto mostra ter funcionado de maneira mais eficaz do que a imposição de uma nova linha de pensamento, como vimos no excerto 2 ("então isso tinha que ser um processo meio que voluntário/ do professor/ não totalmente porque a empresa queria mudar"). 
Se o projeto fosse imposto de maneira mais autoritária, teria provocado não só um aumento de resistência dos sujeitos envolvidos como também um distanciamento das idéias por ele defendidas, pelo menos num primeiro momento.

Da maneira como o projeto foi proposto, haveria uma participação maior dos professores nas decisões tomadas, através da palavra dos multiplicadores, e um maior entrosamento entre a gerência das filiais e seus funcionários. Todos eram "parte do time", estavam "num mesmo barco", prontos para uma jornada ao conhecimento. A própria gerente reconhece que essa vontade de engajamento deveria partir do funcionário, mas não deixa de salientar que a escolha teria, cedo ou tarde, que ser feita ("então todo mundo ia ter que eventualmente embarcar"). Aqueles que não se adequassem aos novos moldes de reflexão passariam a ser vistos como resistentes não só ao ER, mas ao próprio desenvolvimento profissional.

Podemos traçar aqui um paralelo entre a maneira como o projeto foi implantado e 0 pensamento de Foucault (1979/2000; 1988/2001) sobre o poder e a repressão. Partimos do pressuposto que, ao mesmo tempo que o controle da produção do discurso pode bloquear e desqualificar seu objeto, ele incita e intensifica outras produções discursivas acerca desse objeto. Ao se tentar silenciar a resistência, outras formulações sobre a validade de ER na instituição surgiam.

O ER produzia a reflexão que passava a ser desejada não só pela escola mas também pelos professores. As discussões e os saberes produzidos durante as reuniões e discussões entre os professores faziam que os mesmos se sentissem parte do processo e os levavam a pensar como agentes de possíveis mudanças na estrutura da instituição. Nesse sentido, os professores estavam motivados a refletir e a gerar mudanças concretas no tipo de ensino ministrado pela instituição.

Qualquer professor poderia se tornar um PM, estar em contato direto com a gerência e ser respeitado tanto por ela como pelos colegas. Ser um multiplicador era considerado como uma espécie de promoção, passando a contar como critério para 
tal. Para chegar a ser um PM, o professor deveria, entre outras coisas, se mostrar engajado nos projetos de investigação (os TLAPs) e nas reuniões de reflexão. Todo esse ritual era sempre festejado, pois o multiplicador era visto não só como uma pessoa que produzia intelectualmente (estava em seu poder a construção das reuniões), mas como um facilitador da comunicação entre os diversos níveis hierárquicos da escola. Se as reuniões fossem consideradas produtivas pela gerência e pelo membro do departamento acadêmico que as assistisse, toda a filial seria vista com bons olhos pela instituição.

As reuniões seriam um meio de produção de saber e, de certa forma, um pouco do poder seria deslocado, seja para a posição do multiplicador, seja para a posição dos professores que avaliariam constantemente as aulas e o processo. O projeto poderia ser uma maneira de os professores se virem como agentes e não apenas como funcionários controlados pela instituição.

\subsection{A aula com qualidade}

A aula com qualidade seria o instrumento com o qual a escola chegaria ao aumento do número de alunos (apesar de constatarmos que essa aula precisaria agradar antes de qualquer outra coisa). Isso seria conseguido pela constante preocupação da empresa com o desenvolvimento de projetos de alta qualidade, como o Ensino Reflexivo. Só o fato de a escola procurar se empenhar no projeto já é visto pela gerente como uma busca pela qualidade. O projeto é sinônimo de coragem, ambição e, acima de tudo, é tão imponente quanto a própria instituição "numa proposta de tamanha envergadura"7.

A qualidade da aula seria conseguida através da observação dos professores e da reflexão produzida após a aula, momento que a gerente considerava crucial:

\footnotetext{
${ }^{7}$ Palavras da gerente da filial.
} 


\section{Excerto 5:}

G: num/ num processo de reflective/ é a discussão após a observação de aula/ porque na verdade o reflective não veio prá penalizar o professor/ o que ele faz é evidenciar conceitos que estão dentro do projeto ou não/ e isso a gente só detecta com segurança na discussão de aula com o professor/ e nesse sentido o gerente pode avaliar se o professor tem um nível adequado de reflexão e se ele consegue atuar em cima dessa reflexão prá que ahh/ a aula seja melhor cada vez mais

A constante avaliação não deveria penalizar o professor, mas fazer que as aulas mantivessem o patamar de excelência pretendido pela instituição ("a aula seja melhor cada vez mais").

Em outro momento, a gerente faz questão de demonstrar que na busca pela qualidade a instituição não encontra concorrentes. Quando a entrevistadora menciona o processo de treinamento de uma outra escola, ela se adianta em frisar que essa preocupação sempre fora constante dentro da instituição. Ou seja, a qualidade sempre fizera parte da instituição em questão, e a maneira como a aula seria apresentada para os alunos nunca deixou de ser considerada.

Como no sistema empresarial, a aula era o produto a ser oferecido e vendido ao cliente, e isso seria conseguido através de um prestador de serviços bem qualificado, o professor da escola.

\section{Excerto 6:}

G: ah/ que ele só funciona quando a BASE do professor é muito sólida/ então um professor segurol bem treinadol ahh/ conhecedor de diversas formas/ diversas metodologias/ conhecedor dos materiais/ então um professor segurol ele tem ahh/ as ferramentas prá tá podendo abstrairl no nível que o reflectivel propõel então quando a gente ahh/ começou a discutir a aula dentro do ciclo reflexivo/ ele só foi entendido pelas pessoas que têm a metodologia muito segura/ e sabem exatamente o que estão fazendo/ então isso veio como/ como uma fórmula prá padronizar a aula da XXX/ e aí então nesse caso ele funcionou...

O Ensino Reflexivo só pode funcionar, segundo o enunciado da gerente, se ele é colocado em prática por um professor bem treinado ("seguro"). Isso significa que a 
gerente vê nos professores da instituição um potencial diferenciado em relação à concorrência: a reflexão como fator de qualidade. Assim, faz crer que seu produto é melhor que o oferecido por uma outra escola, ajudando a reforçar a idéia de que um professor bem treinado pode garantir a qualidade.

\subsection{A satisfação do cliente}

Uma aula com qualidade seria um pré-requisito para a satisfação dos clientes. Além disso, ela é uma forma de conquistar os objetivos do projeto.

\section{Excerto 7:}

G: [interrompendo]hum hum/ SIM/ mas se ol o projeto funciona em sala de aula você tem por conseguinte um aluno mais satisfeito que queira continuar conoscol essa é a propostal melhorar a percepção de aprendizado do alunol tirar a imagem de que a XXX era chata [a entrevistadora concorda]/ quer dizer dentro disso também poderíamos ficar aqui HORAS discutindo o que É na cabeça do aluno a XXX chatal nél e/ ahh/ é muito simples na verdade/ o PROCESSO não é simples/ mas o efeito do processo é muito simples né/ é o cliente satisfeito

O ER seria usado então como um desencadeador de mudanças profundas de ordem qualitativa no modo de o professor enxergar a sua aula. É claro que, ao se tornar mais crítico e usar suas observações como base para seu desenvolvimento, o professor conseqüentemente melhoraria sua aula, levando o aluno a se sentir mais satisfeito ("essa é a proposta/ melhorar a percepção de aprendizado do aluno"). Como vemos na entrevista com a gerente, "se o/ o projeto funciona em sala de aula você tem por conseguinte um aluno mais satisfeito que queira continuar conosco". Essa conseqüência era vista como natural e lógica ("mas o efeito do processo é muito simples né/ é o cliente satisfeito"), mas não foi o que realmente aconteceu, como veremos ao discutir a avaliação do processo.

Uma das possíveis explicações para esse resultado não ter sido percebido pode estar nos efeitos do discurso da gerência de qualidade total na instituição. Como o cliente precisava estar satisfeito, tentava-se de tudo, inclusive desmerecer o sistema de avaliação para que o aluno passasse de estágio. Isto produziu uma idéia que 
desmereceu o curso em si, colocando-o na posição de uma escola de nível inferior de qualidade. Na visão dos professores, a instituição começou a perder crédito diante dos alunos, e o problema não estava mais em ela ser considerada chata por ser também uma instituição tradicional, como havia mencionado a gerente ("tirar a imagem de que a XXX era chata").

Uma das maneiras apresentadas pela instituição para a solução desse impasse foi a elaboração de uma lista de procedimentos, ou seja, tudo que deveria existir em uma aula, já que o modelo usado (o ciclo experimental) também estava sendo visto como o culpado pela não-eficiência. A própria visão de satisfação do cliente teria que mudar, ou começava a mudar, como a própria gerente assistente enfatiza:

\section{Excerto 8:}

A: [pausa breve] olha/ eu acho que mudou e tá mudando de novo/ porque eu acho que com todo reflective [validação da proposta]/ todaaa/ a essa idéia do cliente/ o cliente tem razão o cliente tem sempre razãol é a satisfação total do cliente/ tudol foi dado muita liberdade pro clientel e agora a gente tá vendo QUE tem limite/ isso tem limite/ então a gente tá mudando um pouco essa postura/ sim/ o cliente tem razão/ até um certo ponto// então a gente precisa ver quais são os valores da XXX/ o que que a XXX tá// vendendo prá esse cliente e a gente tem que ser honesto com o nosso cliente e conosco/ então eu acho que/ nós mudamos/ sim/ facilitamos tudo para o cliente sim/ o cliente tem toda razão e tudo prá não se perder alunol e agora a gente tá vendo quel por estarmos nos comportando por essa/ del dessa formal nós acabamos perdendo também cliente/ porque você acaba enganando 0 cliente temporariamente/ chega um momento que ele vai ver que// não foi certo né

A gerente assistente verbaliza a preocupação de muitos professores acerca da visão do aluno como cliente. O fato de o cliente ter sempre razão, como vimos acima, levou a instituição a dar liberdade demais, até que o aluno exigisse mais do que poderia, mesmo a aprovação nos cursos sem a proficiência desejada. No momento da coleta do nosso corpus, essa preocupação começava a ser valorizada, pois a escola havia notado que "foi dado muita liberdade pro cliente/ e agora a gente tá vendo QUE tem limite/ isso tem limite". 
A lista de procedimentos, ou o que uma boa aula deveria ter, foi introduzida no mesmo momento em que a gerência da filial implantou as Forças-tarefa, ou grupos de funcionários (em nosso caso só de professores) que se responsabilizariam pelo desenvolvimento de planos de ação para alguns problemas que incomodavam a filial, como a disciplina em sala de aula, a recuperação de alunos fracos e até mesmo uma padronização de conduta quanto à correção de lições de casa ou testes. Tudo isso em perfeita sintonia com os princípios da QT transpostos para a educação, como está salientado na crítica de Gentili (2001:151, grifos do original):

(...) a pretensão de traduzir pedagogicamente os princípios de W.E. Deming leva à exacerbação do componente participativo que possuem os modernos programas de controle de qualidade e à ingênua suposição de que os Comitês, Equipes ou Círculos de Qualidade constituem em si mesmos a solução para os problemas da escola.

Em outras palavras, fica clara a idéia de que as forças-tarefa ou a simples vontade do grupo não seriam suficientes para resolver as dificuldades da instituição. O momento de implantação do projeto bem como seus efeitos não eram tão simples de ser racionalizados e solucionados. A escola tinha a princípio colocado em jogo toda a sua visão de educação e gerenciamento, e esse era um processo longo de mudança. Seria ingenuidade achar que os problemas pelos quais a instituição e a filial passavam pudessem ser resolvidos por uma lista geral de procedimentos ou mini-listas. Nem mesmo os tópicos dos grupos formados por professores levavam em conta a opinião dos docentes; eles haviam sido discutidos pelas gerentes de outras filiais e estavam sendo transpostos para os professores da filial em questão. Ou seja, se por uma feliz coincidência alguma das listas tivesse um resultado positivo, o mérito seria da gerente e da sua conduta participativa de gerenciamento.

Enfim, seguindo o modelo neoliberal, o ER era usado como maneira de levar os professores a se empenhar na melhoria de seu produto para satisfazer o cliente e, acima de tudo, exceder suas expectativas. Porém, no momento focalizado pelo nosso trabalho, a filial tentava demonstrar mais empenho na qualidade para contornar a sensação de que perdera o controle do processo perante o cliente. 


\subsection{A constante avaliação}

$\mathrm{Na}$ instituição em questão pudemos constatar vários mecanismos de controle relacionados com o projeto. Durante a entrevista com a gerente, a mesma diz que o projeto de ER é controlado não só através dos funcionários, mas também pelas medidas de satisfação dos clientes:

\section{Excerto 9:}

$\mathrm{E}:$ (...) eu queria saber assim/ o que/ qual relação entre o projeto de reflective/ e a/ a gerência de qualidade

G: muito próxima/ muito próxima/ na questão do controle de qualidade em si que a gente avalia e outras tantas variáveis/ pesquisa de satisfação POR professor / I então a gente olha/ tabula dados/ níveis de desistêncial então é tudo muito científico o que a gente faz reclamações que a gente recebe/ enfim/ eu tenho milhões de formas de tar descobrindo isso e de tá controlando essa qualidade/ o que eu acho importantíssimo num/ num processo

(...) aí tem mil formas de ahh/ se detectar a resistência/ das mais fáticas/ o professor não comparece na/ nas reuniões/ não apresenta projetos de investigaçãol que é os tlaps que hoje ainda continuam/ o nome não importal mas basicamente é uma proposta de investigação a que o professor se propõel nél ahh/ elel até mesmo não participar das reuniões/ ah/ lip servicel que o professor pode estar verbalizando alil e na verdade isso eu já vi muitas (...)

Esse é um dos momentos em que a gerente assume a relação entre a gerência de QT e o projeto, enfatizando a necessidade de resultados e controle do processo ("muito próxima/ muito próxima/ na questão do controle de qualidade em si que a gente avalia e outras tantas variáveis"). Ou seja, a preocupação que norteia sua visão do projeto é como o resultado pode ser medido.

Poderíamos relacionar as medidas de controle de qualidade/ participação mencionadas pela gerente em dois sentidos, através do cliente e do professor: 
Através do cliente:

Através do professor:

pesquisas de satisfação

1. pesquisas de satisfação

desistências

2. número de desistências por professor

retenção de alunos

3. retenção de alunos por professor

4. comparecimento às reuniões

5. participação ativa nas reuniões

6. planos de ação (TLAPs)

Como um dos focos desta pesquisa está no professor, é importante frisar que as medidas de controle acima não levam em conta os outros departamentos da instituição (secretarias, gerência). De qualquer maneira, é certo que o professor é uma peça chave para que o ER seja bem sucedido, já que ele lida diretamente com o produto oferecido (a aula) e o cliente (o aluno).

Dos itens citados pela gerente, só as pesquisas de satisfação poderiam dizer algo sobre a qualidade das aulas, dependendo da maneira como elas fossem aplicadas. No caso da instituição, elas se limitavam a perguntas com respostas fechadas, em que o aluno dizia se estava satisfeito com o curso ou não, se a aula era interessante ou mesmo se o relacionamento com o professor era bom. Não havia espaço para explicações ou motivos pelos quais os alunos estariam ou não satisfeitos com o curso, apenas uma linha para o aluno colocar suas impressões caso desejasse.

Essas pesquisas geralmente eram distribuídas nas últimas aulas do semestre, quando não no mesmo dia da prova final. Os alunos normalmente não se mostravam interessados em respondê-las, pois estavam cansados com o final do semestre e diziam que muitas das suas sugestões não eram ouvidas. Essas sugestões muitas vezes eram relacionadas não com as aulas, mas com 0 funcionamento das lanchonetes ou até com a organização de excursões. As únicas sugestões que posso lembrar acerca da qualidade das aulas eram normalmente 
propostas por alunos adultos, que pediam classes separadas dos adolescentes, ou adolescentes, que gostariam de ter mais vídeos e mais músicas nas aulas.

Apesar disso, o controle continuava a ser visto como altamente científico ("então a gente olha/ tabula dados/ níveis de desistência/ então é tudo muito científico"), como ressalta a gerente. A única maneira de expressar a visão científica seria, então, a numérica. Não obstante toda a movimentação em torno de um ensino mais qualitativo, preservavam-se os números como prova irrefutável do sucesso. Isso nos chama a atenção para outro conflito presente entre o ER e a QT.

\section{Excerto 10:}

E: e nas pesquisas de satisfação/ as pesquisas tem melhorado/ não tem/ da/ da

G: tem/ tem

E: na nossa filial pelo menos/

G: tem/ DRAMaticamente melhorado

$\mathrm{E}$ : nas pesquisas tem melhorado bastante

G: a retenção não/ a retenção pioroul mas as pesquisas melhoraram

Assim, os índices de satisfação das pesquisas haviam melhorado (a gerente diz que "dramaticamente"), porém a retenção estava abaixo da esperada. Se o cliente está mais satisfeito, por que ele não retorna? Por que o número de alunos novos não aumenta, já que a aprovação dos clientes e a propaganda boca-a-boca são consideradas pela instituição como uma maneira efetiva (e até mais bem vista) de marketing? É importante salientar que as avaliações começaram a ser feitas com a presença do professor em sala de aula, o que inibia os alunos de criticar o que acontecia durante as aulas.

A verdade é que os números continuaram reduzidos, apesar de esse dado não ser uma regra geral em todas as filiais. Isso sugere que o tipo de controle seguido pela instituição falhava ao tentar avaliar o processo. Além de os índices de satisfação terem melhorado, os professores da filial eram considerados como engajados e até mesmo melhores que os das outras filiais ao aceitarem o ER. Se esses indicadores 
de qualidade fossem suficientes, o número de alunos deveria ter aumentado, bem como a retenção de alunos antigos.

Nossa opinião sobre essa discrepância de resultados é que a pesquisa desenvolvida pela instituição não era eficaz no sentido de medir a qualidade das aulas. As perguntas fechadas, o momento em que os dados eram colhidos (nas últimas aulas do semestre, muitas vezes no mesmo dia da prova), assim como a presença ou não do professor em classe, acabavam por influenciar os alunos. Isso não quer dizer que os alunos não estivessem mais satisfeitos com as aulas, mas sim que a maneira como esses dados eram obtidos não ajudava a promover nem a melhoria da qualidade das aulas, nem a identificação do motivo que levaria o número de alunos a cair. Esse problema era apontado pelos professores durante as reuniões com a gerência da filial, embora eles não estivessem autorizados a emitir sua opinião, isto é, não eram legitimados pela instituição para tal. A instituição, por sua vez, aparentemente preferia se ater aos números a tentar descobrir as razões para a disparidade.

\section{Conclusão}

Com base em nossa pesquisa, podemos concluir que o projeto neoliberal influencia o instituto de línguas, o que produz diversos efeitos tanto nas áreas administrativas como na pedagógica. $\mathrm{Na}$ área administrativa, é necessário, entre outras coisas, que haja um engajamento de todos os funcionários da escola (cada um com papéis e responsabilidades redefinidas) num esforço para alcançar a eficiência dos serviços. Já a pedagógica procura adequar seus projetos (em nosso contexto o ER) para que as metas da escola de línguas sejam alcançadas.

Ao focalizar a educação em termos de mercado, os cursos passam a ser adaptados de modo que as necessidades dos alunos sejam enfatizadas, e sua satisfação, garantida. Além disso, a preocupação com a sala de aula, que sempre havia tido um sentido pedagógico, passa a se manifestar a partir de estatísticas que se transformam em itens de controle de qualidade. O principal ponto a ser avaliado em 
um professor já não é apenas a qualidade de suas aulas, mas os números que traduzem sua performance: número de alunos rematriculados, número de desistências, número de retenção. Mesmo as pesquisas de satisfação não são vistas a partir dos comentários feitos pelos alunos, mas sim das porcentagens das respostas fechadas.

A fala da gerente da filial estudada resume bem o dilema existente entre o sentido pedagógico do ER e o sentido empresarial do instituto de línguas. Apesar de procurar conscientizar o docente acerca de suas práticas, o verdadeiro objetivo de ER é aumentar a retenção de alunos.

No próximo capítulo, analisaremos os enunciados dos sujeitos envolvidos em nossa pesquisa, procurando enfatizar a construção dos sentidos e o controle do discurso dentro do projeto de ER. Dessa maneira, poderemos verificar de que modo esses sujeitos, entre eles a gerência da filial e os professores, são constituídos de vários discursos, como o discurso neoliberal da QT e o do ER. 


\section{CAPÍTULO 3: \\ O Controle do Discurso}

Este capítulo tem o objetivo de analisar os enunciados produzidos pelos sujeitos de nossa pesquisa (docentes, PMs e gerentes) em reuniões e em entrevistas com a pesquisadora. Esses enunciados, bem como os sentidos produzidos, são nosso ponto de partida para a discussão acerca do controle do discurso (Foucault, 1971/1999) nas reuniões de ER.

Como visamos a um olhar sobre a materialidade lingüística desses enunciados e sua relação com as condições sócio-históricas de produção, optamos pelo quadro teórico-metodológico da $A D$ de linha francesa. Isto porque a $A D$ leva em conta a noção de acontecimento proposta por Pêcheux (1997:19), para quem fatos e declarações são percebidos em conjunto com seu contexto sócio-histórico, juntamente com as memórias que ele pode evocar. A AD vê a materialidade discursiva de um enunciado como uma rede de possíveis associações que leva a diferentes sentidos, o que nos auxiliará no estabelecimento de relações entre os vários discursos do nosso corpus, entre eles o discurso educacional e o neoliberal, que englobam os recortes feitos do discurso dos professores e da gerência.

A descrição do microcosmo da pesquisa feita na primeira parte desta dissertação será essencial para a análise, pois ela é parte constitutiva das condições de produção de nosso corpus. Segundo Orlandi (1999), as condições de produção (CPs) consistem não só dos sujeitos como também da situação, além da memória discursiva. Assim, tudo aquilo que já foi dito ou pode ser dito a respeito de um determinado contexto pode ter significado no momento da formulação de um enunciado. A autora ainda acrescenta que as CPs podem ser consideradas em sentido estrito (o contexto imediato da enunciação) ou amplo (o contexto sóciohistórico e ideológico). 
Em nosso trabalho, o contexto imediato se refere à instituição onde se dá a pesquisa, seus sujeitos, o momento do projeto e seus enunciados. Já o contexto amplo se refere ao interdiscurso. Ele engloba não só o modo como o poder é organizado naquela instituição de ensino, mas também como a escola está inserida no quadro de outras instituições.

Em primeiro lugar, focalizaremos as reuniões de ER a partir das considerações de Foucault (op. cit.) sobre a ordem do discurso. A seguir, relacionaremos os enunciados produzidos durante as reuniões às noções de controle do discurso e de construção da reflexão.

\section{Foucault e a ordem do discurso}

Foucault (op. cit.), ao tratar da produção e do controle do discurso, discute os possíveis parâmetros que funcionam como procedimentos que permitem a legitimação da palavra ou sua exclusão. Esse estudo nos ajuda a compreender a importância da palavra (ou o poder da fala) em diversas situações, especialmente no caso do nosso corpus. Em nosso contexto, as reuniões de ER são um exemplo de como a palavra e os poderes são distribuídos na instituição e de como os saberes são controlados. Destacaremos, então, alguns pontos essenciais para a discussão do corpus desta pesquisa.

Citando Foucault:

(...) em toda sociedade a produção do discurso é ao mesmo tempo controlada, selecionada, organizada e redistribuída por certo número de procedimentos que têm por função conjurar seus poderes e perigos, dominar seu acontecimento aleatório, esquivar sua pesada e temível materialidade.(1971/1999:8-9).

Essa materialidade nada mais é do que a materialidade da língua, dos discursos. Ou seja, sempre há uma tentativa de controle dos discursos através da palavra. Ela deve ser legitimada para que seja aceita, e para isso existem procedimentos que funcionam como sistemas de exclusão e controle. 
Entre os sistemas de exclusão, Foucault (op. cit.) destaca a interdição; a separação e rejeição e a vontade de verdade. A interdição é relacionada ao direito de dizer algo. Por esse princípio, uma pessoa não pode falar tudo o que quer a qualquer hora, em qualquer circunstância, porque nem sempre o sujeito é privilegiado com o poder da fala. Em nosso exemplo, veremos que o multiplicador é legitimado pela estrutura do ER ou mesmo da instituição para ter a palavra final nas reuniões. Além dele, somente o gerente acadêmico ou o da filial expressa suas opiniões sem censura aparente ou mesmo contestação por parte dos outros sujeitos envolvidos, pois está numa posição privilegiada hierarquicamente.

A separação e rejeição, por sua vez, têm como exemplo a separação entre a razão e a loucura. Segundo Foucault (op. cit.), por razões históricas a palavra do louco era vista como nula ou relacionada a estranhos poderes como a adivinhação. Assim, essa palavra poderia até ser ouvida, mas continuava a ser excluída. Hoje em dia, apesar de ser ouvida pelos médicos, sua exclusão permanece.

Já a vontade de verdade está ligada ao desejo e ao poder e se torna cada vez mais forte em comparação com os outros dois (a interdição e a separação), pois apóia-se num suporte institucional. Esse suporte é composto por um conjunto de práticas que determinam o saber e como ele é distribuído, práticas manifestas seja na educação e nos livros, seja na maneira como os saberes exercem sua pressão sobre outros discursos da nossa sociedade. Veremos em nosso corpus que o projeto procura sua legitimação, ora através do discurso da QT que é constantemente reforçado pela lógica neoliberal, procurando sempre encontrar uma melhor relação custo-benefício para o cliente, ora através do discurso educacional do Ensino Reflexivo que visa uma reflexão crítica sobre o ensino.

Assim, o projeto contaria com um saber já aceito e valorizado pela sociedade para exercer sua pressão e controle sobre os sujeitos envolvidos no ER. A "vontade de verdade" funciona excluindo aqueles que por alguma razão não aceitam ou mesmo 
criticam a QT e o ER. Assim como os loucos são privados da palavra ou silenciados em seu discurso, os sujeitos, em especial os professores que não se adequassem ao discurso vigente, seriam excluídos da instituição ou rotulados como resistentes. Do mesmo modo, para um professor se tornar um PM era necessário que ele demonstrasse sua conformidade com as idéias propostas pelo projeto, tudo isso exteriorizado pela palavra.

Além desses sistemas de exclusão, Foucault menciona os procedimentos internos que "funcionam, sobretudo, a título de princípios de classificação, de ordenação, de distribuição" (op. cit.:21): o comentário, o autor e as disciplinas. O comentário tem como exemplo os discursos que são de uma certa maneira repetidos e usados como parâmetros na sociedade, constituindo o senso comum, como é o caso dos textos religiosos, jurídicos ou mesmo literários. Não que esses discursos não possam ser mudados ou que exista uma delimitação clara para um discurso fundador, aquele que seria a origem de todos os outros. O que existe é um constante deslocamento de sentidos no que é comentado. Foucault ainda ressalta que (ênfase do original):

(...)o comentário não tem outro papel, sejam quais forem as técnicas empregadas, senão o de dizer enfim o que estava articulado silenciosamente no texto primeiro. Deve, conforme um paradoxo que ele desloca sempre, mas ao qual não escapa nunca, dizer pela primeira vez aquilo que, entretanto, já havia sido dito e repetir incansavelmente aquilo que, no entanto, não havia jamais sido dito. (1971/1999:25)

Ou seja, o comentário nos ajuda a tentar suprir uma necessidade de completude, uma idéia de que, através da palavra, podemos expressar o sentido real do nosso pensamento, como se fosse possível fixar um sentido a um enunciado independentemente do contexto e dos sujeitos a que ele se liga. Essa idéia nos remete às formações discursivas discutidas na AD (Brandão:1991; Orlandi:1999). O sentido de uma palavra não está nela mesma, mas na relação da palavra produzida com o processo sócio-histórico-ideológico em que ela está sendo usada. 
A formação discursiva (Orlandi,1999:43) determina aquilo que pode ou deve ser dito numa formação ideológica. As formações discursivas representam as formações ideológicas porque os sentidos são determinados ideologicamente, os sentidos das palavras deslizam de acordo com a conjuntura sócio-histórica em que estão inseridas. Orlandi (op. cit.) usa como exemplo os diferentes significados da palavra "terra" para formações discursivas diversas, como para um índio (para quem ela poderia significar "vida"), um agricultor (para quem ela teria o sentido de "sustento") ou para um grande proprietário rural (para quem ela poderia significar "riqueza" ou "poder").

Porém, as formações discursivas não são fechadas, e um sujeito pode estar filiado a várias delas ao mesmo tempo. Assim, seus limites são rompidos e por isso os sentidos deslizam. Um exemplo disso ocorre também em nosso corpus, quando os professores discutem o que é um "texto", que pode estar dentro de um livro didático ou dentro do modelo de aula a ser dado, situação em que por "texto" se entende qualquer tipo de modelo de língua a ser apresentado para o aprendiz, seja na forma escrita, seja em forma de vídeo ou exercício de compreensão oral.

Além do comentário, temos um outro princípio de rarefação de discurso que é o autor. O sentido de "autor" na teoria foucaultiana não está ligado à pessoa que deu origem a um texto, mas ao "princípio de agrupamento do discurso, como unidade e origem de suas significações, como foco de sua coerência" (1971/1999:26). O autor não deixa de ter um discurso que é reconhecido, assim como é importante no discurso científico ou acadêmico que a função do autor exista. A ele é atribuído o valor de verdade, numa busca pela origem do discurso fundador. Veremos nos excertos escolhidos a importância do embasamento teórico para que as palavras dos multiplicadores sejam vistas como verdadeiras. Apesar da legitimação dada pela sua função, o multiplicador tende a recorrer ao seu superior do departamento acadêmico ou mesmo aos autores da bibliografia que permeia o ER para justificar as posições tomadas nas reuniões. 
As disciplinas, por sua vez, são organizadas a partir de um conjunto de métodos e proposições que as tornam verdadeiras. Elas não devem ser consideradas como um sistema fechado, como tudo que pode ser dito a respeito de um tópico. Cada disciplina aceita proposições ou não dependendo de seus paradigmas, fixando limites de aceitação que podem até ser mudados mais adiante. Ainda assim, as disciplinas controlam e restringem o discurso e o que pode ou não ser falado.

Existe ainda um outro grupo de procedimentos que são usados para a determinação das condições de funcionamento dos discursos: a rarefação ou diminuição do número de sujeitos que entram na ordem do discurso. Não entrará na ordem do discurso aquele que não for qualificado para tal. O acesso à ordem do discurso pode se dar através do ritual de qualificação que determina características e papéis a serem seguidos, como os discursos religioso, judiciário e político. Os rituais definem um conjunto de signos que devem acompanhar o discurso dos escolhidos, daqueles a quem é dado o poder da fala.

Da mesma maneira que as pessoas do departamento acadêmico da instituição estudada são reconhecidas por possuir as qualificações para o cargo (por exemplo, um curso de mestrado e a conformidade com as regras da escola), o multiplicador também deve ser reconhecido segundo os parâmetros escolhidos: deve ter um certo número de anos de casa, cursos de especialização na sua área e ainda uma postura profissional adequada (não faltar às aulas, vestir-se discretamente, não reclamar demais).

É interessante notar que as reuniões em que um PM era apresentado para a filial seguiam um certo modelo, como se o indivíduo estivesse sendo anunciado como o novo eleito para ter o acesso ao saber. Primeiro, a gerente da filial tomava a palavra e abria o momento da despedida do antigo multiplicador, que era exaltado por sua contribuição e por algum traço de sua personalidade (paciência com os colegas, capacidade de adaptação, contribuição acadêmica, etc...). O PM receberia, então, flores de todos os professores e aplausos. Depois disso, o novo PM era 
apresentado, sempre com uma lista de qualidades necessárias para o cargo, salientado-se que a escolha fora feita de comum acordo entre os PMs, departamento acadêmico e gerência da filial.

Desse modo, seria quase impossível questionar tal escolha já que a pessoa representava tamanha união entre os diversos departamentos da instituição, quase que uma aliança política. E assim, acabava-se a reunião com uma nova salva de palmas, dessa vez para o novo PM, devidamente autorizado a tomar a palavra. Essa apresentação funcionava como um ritual de posse do cargo, não porque os professores não soubessem a identidade do novo PM, mas porque lhe era autorizado o uso da palavra e seu discurso era legitimado (Foucault, 1971/1999).

Procederemos à análise de trechos das reuniões, tendo em vista como se dá o controle do discurso pela instituição (aqui através da gerente e dos professores multiplicadores) e a construção/ imposição da reflexão.

\section{As reuniões de Ensino Reflexivo}

Organizadas pelos multiplicadores de cada filial, as reuniões mensais de Ensino Reflexivo tinham como objetivo auxiliar os professores na reflexão acerca de sua prática e, ao mesmo tempo, produzir e reforçar saberes que fossem coerentes com as necessidades da instituição. Isto é, apesar de serem consideradas como um momento para a discussão dos problemas e suas possíveis soluções, em que o grupo de professores estaria reunido para dividir experiências e criticar as suas crenças a respeito do ato de ensinar, as "sessões de ER", como eram chamadas, seguiam um roteiro pré-determinado pela gerência da filial bem como pelo departamento acadêmico. Todo o processo era, então, guiado para que as conclusões de cada sessão estivessem de acordo com os objetivos iniciais dos multiplicadores.

É claro que a influência maior ou menor da gerência e do departamento acadêmico nas reuniões estava condicionada à própria participação desses departamentos em 
cada filial. É importante ressaltar que nem todas as filiais davam o mesmo valor ao projeto, e muitas gerentes chegavam a ser chamadas de "resistentes" e "retrógradas" por não demostrar efetivo interesse em um processo de "tamanha envergadura" que estaria "sintonizado com a educação moderna, com as tendências internacionais...que a XXX sempre se preocupou em estar usando as pedagogias mais eficazes e modernas" ${ }^{\prime}$. Como vemos nesse enunciado, o projeto era visto como um tendência que não poderia ser ignorada, nem por um gerente nem por um professor, pois estava de acordo com o que havia de mais moderno na educação. A ênfase nesse excerto não está nos possíveis efeitos positivos do projeto sobre o ensino da língua inglesa, mas acima de tudo "no trabalho escolar de alta qualidade como produto de uma Escola de Qualidade" (Glasser apud Gentili \& Silva, 2001: 144) como reza o discurso de QT. No caso da filial estudada, a gerência se considerava ativa e estava de acordo com o ER, apoiando-o e participando das reuniões. Porém, como o número de professores envolvidos era em torno de trinta e havia uma certa dificuldade de horários que pudessem ser oferecidos para que todos participassem, ficou estabelecido que haveria duas reuniões. Nesse caso, a gerente ou sua assistente participaria em uma delas apenas, o que propiciava uma reação diferente dos professores dependendo da sessão de que participavam, como veremos mais adiante.

\subsection{O controle do discurso nas reuniões}

A relação de controle do saber e da produção do discurso durante as reuniões observadas é constantemente reforçada. Quem aparenta ter um maior controle sobre os enunciados é sempre o multiplicador, que busca autorizar a sua fala de duas maneiras: pela menção da pessoa que é a encarregada geral do projeto no momento estudado (aqui representada pelas letras GA) e pela empatia com os professores, fazendo-os crer que existe uma identificação de propósitos, em oposição à gerência que é vista negativamente. Vejamos este excerto do início de uma reunião em março de 2000.

\footnotetext{
${ }^{8}$ Palavras da gerente da filial estudada em entrevista com a pesquisadora, grifos da própria gerente.
} 


\section{Excerto 1:}

PM1: the objective of the session today is to work (with) all the phases of the cycle// and/ although/ we are not going to work/ ahn/ in DEPTH/ you know?/ because we still haven't got all the answers for all your questions that might/ ahn/ emerge during the session [tosse]/ in relation to the other phases cause/ ahn/ we haven't discussed with GA [o nome do gerente acadêmico responsável pelo treinamento dos PMs] yet/ okay

PM2: in our last meeting with GA multipliers and/ GA still discussed about the concrete experience phase so/ what we are doing/ ahn/ here is ahn/ trying to go a little further cause everybody has asked to see/ the whole and so we

PM1: mainly because in the other branches they are STILL working with the concrete experience phase/ we have

Nesse excerto vemos que a duas multiplicadoras tomam a palavra para explicitar os objetivos da reunião que começa. Num primeiro momento seu enunciado estabelece uma relação de cumplicidade com os participantes, salientando que elas ainda não terão todas as respostas para as dúvidas. A utilização de "we", nesse enunciado, pode remeter tanto às duas multiplicadoras como treinadoras, como às multiplicadoras como parte da formação discursiva dos professores. Assim, estabelece-se um vínculo de mútua ajuda. O grupo, como um todo, não pode entender todos os procedimentos relacionados com a nova abordagem de aula, por isso precisa construir esse conhecimento. As multiplicadoras e os professores estariam fazendo parte do processo de reflexão proposto pelo ER de Richards e Lockhart (1994) e usando o pressuposto de que muito pode ser aprendido a partir de um entendimento do ato de ensinar através da reflexão crítica. O modelo de aula a ser discutido funciona como base para essa reflexão, que deve ser aprofundada cientificamente pelas teorias estudadas ao longo do projeto, por exemplo, as teorias de aprendizagem.

Ao mesmo tempo, a PM2 (segunda multiplicadora a tomar a palavra) faz questão de salientar que a razão pela qual elas não têm todas as respostas é que a reflexão ainda está em curso com o gerente acadêmico. O sentido produzido por esse tipo de comentário entre os professores observados é de que o detentor do discurso 
fundador, de todas as respostas e formulações a respeito dos conceitos estudados estaria na pessoa do gerente acadêmico, que abriria mão de seus conhecimentos à medida que os outros sujeitos envolvidos estivessem preparados, sempre na seguinte ordem hierárquica: da gerência acadêmica para a gerência da filial e/ou multiplicadores, e desta para os professores.

No começo os professores não tinham acesso a grande parte da bibliografia que embasava o projeto, e só depois da coleta desse corpus é que circulou entre as filiais uma fotocópia com os conceitos sobre o ensino experimental de Kolb (1984). O comentário vigente era de que antes os professores não estariam preparados para lê-lo, numa demonstração de controle do saber e do poder. O departamento acadêmico seria a voz da instituição capaz de saber o momento ideal para repartir seus conhecimentos.

Mesmo assim, as PMs sugerem que os professores da filial são considerados melhores que os outros, mais avançados, ao dizer que as outras filiais "STILL" ou seja, "ainda" estariam trabalhando com a primeira fase do ciclo, e não com todas as quatro, como ocorreria naquela sessão.

Maingueneau (2002:27) aponta para a necessidade de recorrer a regras pragmáticas para determinar o sentido do enunciado. Para entendê-lo, seria preciso analisar o contexto, não apenas fazer uma interpretação semântica. Em nosso excerto, estaríamos ligando o contexto do enunciado ao uso do advérbio "ainda" (com ênfase na palavra). Ele liga duas proposições: a primeira diz respeito ao conteúdo a que os professores da filial estão sendo expostos (todas as fases do ciclo). Segundo essa proposição, os professores da filial estavam mais avançados no processo do ER. A segunda proposição, por sua vez, nos dá uma visão das outras filiais (que trabalham os conceitos da primeira fase), ou seja, as demais filiais não haviam chegado tão longe a ponto de ter uma visão completa do ciclo na aula. 
O advérbio produz, então, um sentido que é reforçado ainda mais pelo aumento no tom de voz da PM. Por conseqüência, o fato de os PMs não terem todas as respostas para as perguntas seria relevado (we still haven't got all the answers for all your questions that might/ahn/ emerge during the session [tosse]/ in relation to the other phases cause/ ahn/ we haven't discussed with GA (...) yet/ okay). Ao mesmo tempo, as qualidades do grupo seriam exaltadas, pois estar à frente das outras filiais passaria a significar mais do que não ter todas as dúvidas resolvidas. Uma possível crítica às PMs (o despreparo) é transformada em elogio aos docentes.

Num outro momento, a multiplicadora estabelece novamente um vínculo com sua audiência ao ressaltar que muitas dúvidas apresentadas pelos professores já haviam feito parte de sua experiência:

\section{Excerto 2:}

PM2: and another thing/ it was ahh kind of a breakthrough for me in in the in the february sessions/ was that GA was saying how we we used that we have changed the focus/ a little/ ahh and and the second / some of you were saying this active production phase and GA was explaining to us that the REAL/ the real second ce [fase do ciclo] only happens in real life [alguns professores parecem aliviados]

PM2: some of you were saying this/ this second experiment phase have/ looks like our second experiment phase/ so that's why here and this is/ a little change in focus/ and II and I remember that some of us were/ were in doubt about that last semesterl this this second ae [novamente é usada a pronúncia das duas vogais, aqui para identificar a "active experimentation"] should be as free as possible

Ao procurar novamente a fonte do discurso na instituição, PM2 reforça seu enunciado da mesma forma que o discurso acadêmico cita suas fontes. Não é ela, mas sim sua posição como multiplicadora que lhe garante ao mesmo tempo a autoridade para determinar o que é correto no contexto (provando suas fontes) e o estabelecimento da ligação com os professores. Mais uma vez ela usa "some of you" e "some of us", que, apesar do uso do partitivo "some of", faz com que os sentidos e as identidades envolvidas se multipliquem: "some of you" serão os professores da 
reunião citada ou os professores da filial/ instituição que ainda têm dúvidas? "Some of us" estaria incluindo os multiplicadores reunidos ou todos os que fazem parte do projeto? Usar nós aqui induz o ouvinte a acreditar que o que é dito faz parte de um consenso geral.

Mais adiante, as multiplicadoras tentam fixar os termos e a maneira de abordagem a ser usada através do jargão usado pelo aprendizado experimental de Kolb (1984).

\section{Excerto 3:}

P1: because I've seen/

I dont know/ I've been doing the following/ I've been starting with the role play/ something like that/ we are going shopping/okay?

P?: okay

P1: something like that/ you are all going shoppin/ or something like that/ and then we diagnose and maybe// ROLE play again

PM2: you are going to understand now why this role play $I$ is placed on in the ro [abreviação de Reflective Observation] right/ but THEY kind of overlap/ they kind of come together

P2: all right

PM2: so/ ahh// in the reflective observation what we mean here by text is not any kind of written text but/ but any kind of PRODUCTION/ so it can be a video/ it can be a dialogue/ it can be a listening/ it can be a written text THAT// there is// between inverted commas then

PM2: is it the teacher's text or the student's text? so the text/ the text is the text that there is there or/ or you have both?

P3: it's difficult [essa professora fez um comentário sobre o uso da metalinguagem e como ele acabava dificultando o entendimento do que as PMs queriam dizer durante essa sessão](...)

O "RO" compreende a observação reflexiva do ciclo experimental, uma das fases que devem ser entendidas e usadas como parte do plano de aula atualizado. $\mathrm{O}$ professor P1 confirma nesse excerto quais os procedimentos que definiriam o RO, confirmação que só poderia ser dada ou validada pela multiplicadora, já que ela está no lugar do gerente acadêmico na sessão.

Além disso, PM2 também explicita o significado de "texto" nessa formação discursiva, da qual fazem parte os profissionais da área de educação. Ela ressalta que o "texto" é qualquer tipo de produção em que a língua alvo a ser trabalhada em 
classe está inserida. Esse tipo de clarificação se faz necessário e ainda é alvo de comentário por outra professora (que coincidentemente já havia sido multiplicadora). O comentário diz respeito ao tipo de metalinguagem usado com a palavra "texto", o que acaba por dificultar o momento da reunião, já que o tópico principal da conversa passa a ser o uso da metalinguagem em contraposição à importância do modelo a ser apresentado ao estudante. Essa discussão acerca do termo também faz parte do discurso educacional que permeia o projeto.

A autoridade das multiplicadoras no corpus estudado só não é maior que a da gerente, que em diversos momentos toma a palavra durante as reuniões e discorre sobre todo tipo de tópico discutido. Apesar de a própria gerente salientar nas entrevistas que o conhecimento deve ser construído pelos professores e que a organização do projeto é horizontal, ou seja, todos devem participar opinando sempre que necessário, sua fala funciona como um interdito: ela toma a palavra de tal maneira e por tanto tempo que as multiplicadoras têm que assumir uma posição de total respeito à hierarquia, esperando que a palavra volte ao seu controle. Nesse momento, os professores também são silenciados, e a discussão se torna quase um monólogo.

\section{Excerto 4:}

PM1: ahhn// we need to interrupt/ sorry but/ you know sorry

PM2: now we'd like to give you the feedback we have Ignes [nome fictício]// BUT we would like you to present this lesson in the next session next okayl bring in all your problems alll your doubts because the checklist is yours/ Amanda [nome fictício] the checklist is yours

P4: THANK you

PM2: feedback feedback

G: before you start giving your feedback, I wou/ I would like to say something I I'm going to talk about what happened in our group over there cause I think it's important impor/lt's also a big question we can't go away without sharing that ahh we were preparing a lesson/ one lesson on emotions in in our group there and so and thought then I asked in the end of the lesson and I asked thought would we have a cycle a/ big whole unit/ in our mind for the cycle/ for the whole unit and that's not the question 
Podemos notar aqui como a gerente toma a palavra durante uma reunião que havia chegado ao fim. É importante clarificar que, apesar da gerente estar mencionando problemas que foram discutidos na reunião em questão, ela o faz numa hora inapropriada, pois as multiplicadoras haviam acabado de dizer que todas as questões seriam bem-vindas na próxima reunião ("bring in all your problems"). Apesar disso, a gerente insiste que sua palavra de certa maneira vale mais que a das multiplicadoras, pois é ela quem recomeça, ou ao menos procura recomeçar a discussão que deveria ser o tópico de uma próxima reunião, dizendo "I would like...", "I am going to...", "I think...", para finalmente terminar com "we can't go away without sharing...". A escolha dos vocábulos e sua ordem são interessantes e acabam por sugerir que seu comentário vai de um pedido ("I would like to say...") a uma imposição ("We can’t go away without sharing"), que podem ser fruto de sua vontade ("I am going to", que indica intenção e "I think"), pois há algo que a aborrece. Vejamos como a gerente reforça sua palavra no próximo excerto.

\section{Excerto 5:}

G: ... a question a cycle for the lesson and that's not the question but that is disturbing me for the moment but then we got to/ you were thinking about the ce [fase do ciclo] and the social act and/ one suggestion that came up was ahh can you say it/ your suggestion

P4: I I would ask them/ ahh to imagine that they meet and the friend doesn't look very well so/ you're probably going to ask the (..) hugh about his or her emotions and you'll come up with sad/ depressed on something like that G: hopefully $\mathrm{PI}$ [a gerente usa as primeiras letras de curso de préintermediário] so I it's it's never to me a CE [experiência concreta, fase do ciclo de aprendizagem reflexiva] / PI1 so I'm thinking about this cause I'm not teaching so it's never to me a concrete experience/ thinking in the process that goes on in my mind so THAT's/ that the the situation/ that activity// would pick to (...) I imagine because they are only PI1 student and then I thought then this is a role play (...) okay? kind of/ you're simulating a situation/ well I'm thinking while I'm saying thinking while I'm saying this to you because it could be of a hum concrete/ a social act but then I thought// why not have the student to bring something that actually happened to them/ (...)so much [alguns professores concordam com a cabeça] as to you meet a friend// and ahh why why I'm saying this because/ I'm worried about the// danger of US doing role playing and exercises and/get mixed up with/ and exercise of a role play could be a CE for the student/ on the OTHER hand I'm thinking well but you know we DO ask you look terrible or you look great ahh 
tá apaixonada ahh I'm always doing that with when somebody looks particularly well

Chama a atenção o número de vezes em que ela usa o pronome na primeira pessoa do singular, em oposição às multiplicadoras que tendem a expor suas idéias usando a primeira pessoa do plural. De uma certa maneira, isso produz um efeito de que a gerente está numa posição que não será questionada por outra pessoa na filial, nem mesmo a multiplicadora. Ela detém a palavra da instituição e é autorizada a usá-la. Por isso, pode interromper a reunião e expor suas idéias sem ser incomodada pelos professores ou pelas PMs.

Ao usar o pronome pessoal em primeira pessoa ("I"), a gerente pode apenas referirse à sua pessoa. Mesmo assim, esse "I" pode sugerir diversas posições de sujeito: o "I" gerente, que deve coordenar a filial; o "I" professora, pois a gerente também tem uma formação docente; ou mesmo o "I" instituição, que evidencia os objetivos da gerência de QT. Essa repetição do pronome sugere que o seu "I" sobrepõe o "We", ou seja, a palavra da gerente é mais importante que a dos docentes ou mesmo das PMs. Enquanto as PMs parecem fazer uso do pronome em primeira pessoa do plural ("We") para estabelecer uma cumplicidade com os professores, o "I" da gerente comanda o que deve ser feito, mesmo depois de as PMs já haverem dito que outras dúvidas seriam tratadas em outra reunião (excerto 4).

Os professores, nesse caso, tendem a concordar as suas idéias da gerente (concordam com a cabeça) e a falar somente quando são solicitados ("...can you say your suggestion"). Ao procurar participar das reuniões e expor suas idéias o máximo possível, a gerente parece demonstrar que sua autoridade e seu saber vão além da sua função de administradora. Ela estaria também se filiando à formação discursiva da qual os professores fazem parte, pois se coloca na posição de educadora e demonstra estar engajada no projeto de ER, como é esperado pela instituição.

Ao mesmo tempo, o silêncio dos professores não significa necessariamente que tudo que é falado pela gerência é aceito como verdade. Orlandi (1997:44) afirma que 
"o silêncio não fala, ele significa". Ao analisá-lo discursivamente, percebemos que o silêncio pode estar carregado de sentidos. O que os professores deixam de falar pode ser visto como o implícito, considerado um subproduto do trabalho do silêncio. Para a autora, só poderíamos torná-lo visível através da observação indireta "por métodos (discursivos) históricos, críticos, des-construtivistas" (Orlandi, op. cit.:47). No caso das reuniões de ER, o silêncio pode significar tanto um acordo (ao concordar não seria necessário acrescentar nada) como uma censura (não é possível discordar de um gerente). A aceitação da palavra da gerente, por sua vez, demonstra ser proporcional ao respeito à hierarquia na instituição. Como os professores sabiam que sua palavra valia menos que a da gerente, imaginavam que poderiam sofrer sanções disciplinares.

Uma outra forma de controle do discurso está na maneira como as reuniões são estruturadas e o tipo de pergunta que é feito para os professores. Esse controle certamente nos remete à maneira como se dá a construção (ou imposição?) do conhecimento durante as reuniões, o que não deixa de ser uma forma de controle da produção de sentidos. Apesar desse controle, a reflexão não deixa de existir, nem mesmo a construção de outros saberes além daqueles reforçados pelas PMs. A própria maneira como os professores se posicionam nas entrevistas e reuniões pode ser vista como resultante da reflexão, não só sobre a aula, mas sobre o papel do profissional dentro da instituição.

As reuniões analisadas pretendiam fixar os novos moldes de aula, bem como discuti-los. Porém, como esse novo modelo já estava institucionalizado, sua aceitação seria obrigatória. Por isso, era necessário criar um consenso entre os professores acerca de sua eficácia, além de uma homogeneização de procedimentos. Assim, o controle das reuniões, ou do que era externalizado, seria inevitável. Vejamos o seguinte trecho extraído da reunião em que os professores apresentariam suas aulas nos moldes do ciclo: 


\section{Excerto 6:}

PM2: so then what we could do is the following/ those of you who have/ prepared/ that were together in the last session you can come first and we discuss ahh the lessons and those of you whoo who/ ahh/ who do not have a ahh the group that was working in the last session then you kinda of explain your outline/ the lesson/ (...) is it okay?

[alguns Ps concordam com a cabeça]

P3: oh well it's fine for what (...)

PM2: while ahh we have the presentations

Ps: [risos]

PM2: we would like you to follow// to follow to follow to follow what?

P?: what?

PM2: we would like you to follow a few questions/ yeah it's another kind of checklist

P3: yeap

PM2: so a few questions and then we will make ALL the comments in the end of the presentation okay? so if you need/ do you need any paper?

As apresentações deveriam seguir um modelo, uma lista de procedimentos, que não é a primeira a ser preparada, como reconhece a própria PM2 ao responder a uma professora ("yeah, it's another kind of checklist", grifos nossos). Essas listas de procedimentos tinham por finalidade dirigir a discussão e qualquer tipo de comentário para os objetivos da sessão, numa tentativa de restringir a possibilidade de questionamento. Através de perguntas fechadas, os professores veriam se o modelo era ou não seguido. A lista, nesse caso, consistia de perguntas relacionadas com as quatro fases do ciclo (a experiência concreta, a observação reflexiva, a conceitualização abstrata e a experimentação ativa, discutidas no Capítulo 1, página 20).

\section{Excerto 7:}

PM2: so/ questions? comments?

[uma professora se desculpa por não estar passando bem e não poder opinar] P5: any questions?//according to your questions [risos]

P6: yeah/ according to your checklist? did we skip anything?

P5: come on

PM1: the grid was the the ac [soletrando o nome de outra fase, a conceptualização abstrata] the grid was the ac

P5: yes

P6: the grid was the acl yes

P5: yes/hum hum/ the grid and also to ahh analyse the transparency back/ 
yes/ to analyse the transparency and to make/ to make comments together (...) that was the ac

PM1: um hum

No excerto acima, notamos que os professores já estão habituados com o tipo de discussão que acontece. Quando PM2 pergunta se há dúvidas, eles logo se remetem ao modelo de perguntas previamente discutido, como se já estivessem treinados a responder esse tipo de questionamento. Não há resistência aparente, e sim uma troca de perguntas e respostas que visa autenticar o que é imposto pelas multiplicadoras ("...according to your checklist?", grifos nossos). Contudo, há outros sinais que podem ser compreendidos como resistência: os risos e o comentário de duas professoras (P5 e P6). Elas demonstram que estão cientes de seu papel na reunião (pois suas respostas são quase automáticas), como se respondessem às perguntas conscientes da falta de espaço para uma efetiva discussão, que provavelmente traria críticas ao modelo. No contexto da instituição, muitas das discussões sobre os temas relativos ao ER aconteciam na sala dos professores, em geral longe dos olhos da gerência.

Todos os comentários extras seriam dirigidos para o final da apresentação. Assim, o que não era pertinente aos olhos das PMs poderia ser deixado para mais tarde e talvez até esquecido, pois dependendo do número de comentários a sessão não seria suficiente.

\subsection{A reflexão construída e/ou imposta}

O desenvolvimento de uma abordagem mais crítica sobre o ensino deveria proporcionar aos professores uma melhora na qualidade de seu trabalho à medida que o questionamento os levasse à teorização sobre como possivelmente se dá a aprendizagem de língua estrangeira. Essa reflexão não deveria consistir apenas da experiência do professor, pois ela é considerada insuficiente como base de desenvolvimento (Richards and Lockhart, 1994:3-4), mas também do interesse pelo que acontece no processo de aprendizagem. A experiência de Ensino Reflexivo discutida em nosso contexto foi imposta aos professores, auxiliada, de certa forma, 
pelo modelo da gerência de QT. Apesar de a preocupação com a importância da reflexão para a vida do professor como profissional engajado e conhecedor das teorias de ensino já existir antes mesmo do avanço da QT, esse modelo reforça essas características, salientando-as como imprescindíveis para o alcance das metas. Discutiremos, a seguir, alguns momentos em que a construção/ imposição da reflexão ocorre durante as reuniões.

Uma das dificuldades que os professores encontravam era a adaptação dos livros didáticos ao modelo de aula desejado. Isso porque a referência à realidade concreta, ou seja, ao contexto social em que a língua seria usada nem sempre era fácil de ser planejada, de modo a evitar o dispêndio de um tempo grande da aula. A discussão durante a reunião era, então, sobre como alcançar o "ideal" de aula, ao invés das vantagens desse modelo. Vejamos este excerto retirado da reunião de março de 2000.

\section{Excerto 8:}

PM1: so in this case [um professor sugere algo]

P7: the students' text and the teacher's text / they should be (...) in terms of what skill there/ what kind of skill they are ahh/ so if they are

PM2: yeah/ my/ GA says something like in the IDEAL world is/[ela gesticula as aspas e os professores riem] he mentions that a lot/ it would be nice if you could compare the same kind of text they are producing to some kind of model

PM1: as (...) as possible

PM2: specially because ahh/ the difference in style and/ ahh/ we also/ it was also mentioned in ourl in our sessions with GA with/ the multipliers that/ there are some books/ where it's more difficult/ to fit/ the cycle/ but the cycle should be fit in ALL our lessons [a PM1 concorda com a cabeça] [risos e tosse]

$\ldots$

[vários Ps mencionam algo sobre não ter que começar a aula de uma mesma maneira]

P11: sorry to interrupt

P7: what we said though/ what would be boring is/ was like this BEGINning/ put them in a situation blablabla in the shop/ it can/ it kinda/ it kinda you know/ it can be in my opinion kind of repetitive (...) or something/ I think it would be PM2: it's the same question that was mentioned in our multiplier session / we had a very nice discussion on/ about the same issue 
PM1: yes [concordando]

P7: being repetitive

PM1: being predictable/ being too predictable

P7: nice

PM2: NOW let's/ move on/ move on/ abstract conceptualization/ oh I can't see/

Destacaremos dois pontos nesse trecho. O primeiro é a reação dos professores às respostas dadas pelas multiplicadoras acerca das dificuldades para encontrar modelos ideais de conversas com os quais os alunos pudessem comparar a sua produção. Seria impossível encontrar um livro didático ou mesmo outro material que pudesse reproduzir a diversidade das conversas autênticas dos falantes de uma língua ("in the ideal world..."). Os professores reagem com uma certa conformidade a esse problema, pois já ouviram o termo "in the ideal world" falado pelo próprio Gerente Acadêmico e sabem que isso sugere que não há uma resposta pronta para tal dificuldade.

O segundo ponto a ser destacado é que os professores riem ao ouvir que o modelo deve ser inserido em todos os planos de aula ("...but the cycle should be fit in ALL our lessons"). Se o ciclo deveria estar em todos os planos de aula, onde está o espaço para a reflexão? Se não havia uma abertura para que o ciclo fosse questionado durante as reuniões, a reflexão estava relegada a um segundo plano, não a reflexão sobre o ensino da língua inglesa como língua estrangeira, mas sim sobre como melhorar um plano de aula. As PMs usam novamente o dispositivo de mencionar o próprio gerente acadêmico responsável pelo projeto para que seu enunciado seja validado, e os professores demonstram que entendem a mensagem ao rir e concordar com as multiplicadoras.

Mais adiante, os professores tentam chamar a atenção para o fato de as aulas parecerem entediantes para os alunos por sempre terem o mesmo modelo ("put them in a situation blablabla"), que, de acordo com sua opinião, é "boring" e "repetitive" e "predictable". A PM perde, então, mais uma oportunidade de discussão, atribuindo a responsabilidade pelo modelo para o gerente acadêmico, ao mencionar 
que esse comentário já havia sido feito em uma "very nice discussion" sobre o tema. É claro que dizer que as PMs tiveram uma discussão muito boa sobre o tema em nada diminui o problema. Como não é aberto espaço para discussão, P7 acaba por desistir do questionamento, mencionando apenas "nice". A reunião é, então, rapidamente desviada para outro tema.

É interessante notar que os professores e as PMs demonstram ser, de certa maneira, constituídos pelo discurso da instituição e pelo controle que ela exerce sobre seus funcionários. Essa reação de conformidade e apatia mesmo ao não conseguir argumentar sobre problemas que os afetam diretamente (a falta de motivação em sala), já havia aparecido sob outras formas. Em conversas informais ou mesmo reuniões feitas nas filiais antes mesmo do ER, nas quais os professores questionavam o número de alunos em sala de aula, a então gerência dizia que estes eram "givens" na instituição, ou seja, assuntos que deveriam ser vistos como naturais ou impossíveis de serem mudados. Isto significava que haveria espaço para discutir a melhor maneira de lidar com esses assuntos, mas não havia a possibilidade de mudança; neste caso, não haveria possibilidade de o número de alunos ser reduzido. O grupo passou, então, a se referir a qualquer ponto que não pudesse ser mudado como um "given", de maneira jocosa. Quando se dizia que determinado aspecto da escola era um "given", havia o consenso de que ele não deveria ser discutido, apenas aceito. Os professores não faziam mais questão de demostrar o seu desagrado, seja por medo de retaliações, seja porque já haviam desistido de expor sua preocupação, procurando meios para que as conseqüências desse "given" fossem minimizadas.

Assim como na época em que foram expostos os primeiros assuntos não discutíveis, o ciclo demonstrava que também era imposto, já que todos os livros, mesmo aqueles que não fossem do estilo do ciclo, deveriam ser adaptados. Porém, falar que o projeto ou mesmo o ciclo era um desses assuntos não discutíveis não era visto com bons olhos pela gerência geral da instituição, pois para ela estava havendo uma construção de conhecimento através do ER, e não uma imposição de 
valores. Assumir que o ciclo era um desses assuntos não discutíveis era assumir que todo o projeto era uma imposição. Seria melhor aceitar a orientação da PM ("nice") e passar para o próximo assunto em pauta.

Mesmo esse enunciado apresenta contradições quando analisado junto com a fala da gerência acadêmica durante uma plenária realizada em agosto de 2000. Nela, a instituição pretendia discutir e esclarecer algumas afirmações que acabavam por ser repetidas pelos professores, ou seja, a proposta da plenária era a homogeneização do discurso entre os professores de todas as filiais, pois se esperava que fosse possível "...to find and establish a common ground, a common understanding" "encontrar e estabelecer uma base comum, um entendimento comum" (nossa tradução). Um dos primeiros enunciados a serem discutidos se referia a "toda aula tem que estar no ciclo". GA sustenta que:

\section{Excerto 9:}

GA: which tells teachers are in a sort of hysteria if they are trying to fit/ sort around/ tag/ square/(...) all lesson had to be in the cycle/ (...) people would be punished if the lesson were not in the cycle/ we would be the torturers/ the fact is/ this cycle just only organises the lesson/ it is a description of the overall organisation/ it doesn't say how a lesson should be taught in terms of techniques and deliveryl this is something we'll exploit in the other sessions today/ this description of the overall phases of the lesson/ all we ask the teachers to do at this stage of the product/ is to experiment with the cyclel for many course books it is very difficult to do so because the course books and the cycle don't really fit very well/ we are very aware of that/ the course books have been changing/ then in the future/ I think all the course books will look like the cycle/ and at this stage not all of them do/ so the palavra de ordem here is/ relax/ menas

Nesse enunciado, o gerente acadêmico tenta acalmar os professores e chega a chamar a preocupação de "histeria". Ele ressalta que o ciclo deve ser visto como uma maneira de organizar a aula e reforça a idéia de que nem todos os livros se adaptam ao modelo (diferentemente do que dizia nas reuniões com os PMs, nas

\footnotetext{
${ }^{9}$ Fala de um dos Gerentes Acadêmicos durante plenária do início do semestre (agosto/2000) aos professores da instituição.
} 
quais adiantou que todas as aulas deveriam ser adaptadas mais cedo ou mais tarde), assim como as PMs exteriorizaram na reunião citada. Qual seria o motivo da diferenciação entre os sentidos produzidos nas reuniões estudadas a respeito do uso do ciclo e o sentido dado pelo gerente acadêmico, de experimentação? No nosso entender, esse deslizamento de sentido ocorre ao se analisar não só o contexto do projeto na filial estudada, como também o discurso dos gerentes acadêmicos durante a palestra citada.

Devemos lembrar que na filial todas as observações de aula estavam sendo feitas tomando-se por base o ciclo e os Planos de Ação Semestrais (TLAPs) de cada professor, sendo que essas observações muitas vezes eram usadas como avaliação, a despeito das orientações da gerência acadêmica. Durante uma das reuniões, a gerente da filial chegou a dizer que:

Excerto 10:

G:... but it is also an element of control/ quality control/ and we can't take that away/ I can't/ eu vou lá toda bonitinha/ aí eu faço carinho em você/ sabe/ assisto sua aula//(...) I'm your managerl I'm the one who employeed youl I'm also the one with authority to fire youl I'm not here to fire youl but I know this is part of of the image that you have of mel so it's different/ from a coach or a mentor watching you/ with the aim of helping you/ so well be having quite a bit of that/ so that we can see what we need to do in terms of/ you know cause I watch/ I observe about eight teachers/ because its not/ oh/ walk into the classroom and observe/ I like to discuss the class before/ spend THE time that is needed afterwards in the discussion/ because I think that the most important part of of classroom observation/ is the discussion afterwards/ you know it's very time consuming [continua falando sobre a observação] eu vou lerl rotulo/ a professora é boa/ não preciso me preocupar/ faz reflexão

Ou seja, apesar de uma das diferenças ressaltadas entre o modus operandi antes e depois do ER ser o tipo de observação de aula feita, em que deveria prevalecer o intuito de auxiliar o professor no seu crescimento, a gerente faz questão de frisar e assumir que a avaliação faz parte da sua imagem de gerente e do que é esperado dela ("I'm also the one with authority to fire you"), pois ela é a pessoa legitimada para tal. De acordo com sua fala, poderíamos dizer que algumas das atribuições de 
um gerente dessa instituição são: empregar e demitir funcionários, além de observar e discutir aulas com os professores com o intuito de fazer avaliações de desempenho.

Ao mesmo tempo que diz ter autoridade para demitir, a gerente tenta reverter a gravidade de seu enunciado (pois o grupo de professores não se sentiria bem com essa ameaça) com a frase "I'm not here to fire you". Apesar de produzir um sentido de que demitir não seria sua intenção, ela revela que sua observação de aula não tem o mesmo intuito que a observação dos "mentors" ou "coaches", que é de auxiliar o professor ("with the aim of helping you"). Nesse enunciado, ela sugere que a aula é um elemento de controle de qualidade e que seu julgamento não se baseará em sentimentos ("we can't take that away/ I can't/ eu vou lá toda bonitinha/ aí eu faço carinho em você/ sabe/ assisto sua aula").

$\mathrm{Na}$ realidade, a conjunção "mas" já está implícita antes mesmo de aparecer materialmente no enunciado ("I'm also the one with authority to fire you/ I'm not here to fire you/ but I know this is part of of the image that you have of me"), o que nos leva novamente à importância de se ir além das regras pragmáticas para a interpretação de um enunciado (Grigoletto, 2002). Quando a gerente fala "I'm also the one with authority to fire you, I'm not here to fire you", ela coloca duas orações de sentidos opostos juntas: uma que remete aos poderes de demissão de um gerente, e outra que parece tentar assegurar que ela não lançará mão desse recurso.

O interessante neste enunciado é o deslizamento dos sentidos, pois, logo após confortar o docente, a gerente lembra da imagem que faz parte de seu cargo (de alguém com poder de demiti-lo), deixando uma dúvida se esse pressuposto é correto ou não.

Embora se mostre interessada na discussão da aula ("I like to discuss the class before/ spend THE time that is needed"), a gerente parece não conseguir se 
desvencilhar do seu papel de poder e controle sobre os professores, pois ela chega mesmo a rotular os mesmos como bons ou ruins. Diante de um quadro assim, seria normal os professores se tornarem altamente críticos quanto a sua própria produção e preocupados em estar com todas as aulas dentro do ciclo. Da mesma forma, não era possível sair da esfera da filial e levar o que ocorria dentro de cada uma delas para a gerência acadêmica, pois a autoridade da gerente da filial (e conseqüentemente a hierarquia) não poderia ser sobreposta.

Assim, se a palestra dos gerentes acadêmicos tinha como função relacionar e discutir vários sentidos produzidos pelas reuniões de ER, deveria também proporcionar um certo alívio nos professores diante das mudanças ocorridas nos últimos meses na instituição com a implementação do aprendizado experimental. A idéia principal seria fazer que os professores se sentissem mais seguros com o que estava sendo discutido nas reuniões do projeto ("...so the palavra de ordem here is relax, menas"). O tipo de linguagem mais informal usado pelo gerente acadêmico também contribuía para que a ansiedade dos professores fosse controlada.

Como já pudemos notar nos excertos usados para discutir o controle do discurso no ER, as multiplicadoras usam uma lista de procedimentos ("checklist") dada aos professores para a avaliação das aulas de forma a manipular suas respostas de acordo com os propósitos de suas reuniões:

\section{Excerto 11:}

PM2: GA GA [PM2 usa um tom mais alto de voz] is preparing a checklist for all the phases of the cyclel so far we have gone as far as the ce [pronuncia as duas letras em inglês, neste caso é a abreviação de "concrete experience"] which is the one/ [risos] we have already / we have/ given to you

[PMs projetam uma transparência com a lista de procedimentos]

Essa lista de procedimentos, por exemplo, não havia sido preparada pelos professores a partir de sua discussão sobre as fases do ciclo, nem mesmo pelos multiplicadores de todas as filiais com o intuito de propiciar um resultado mais 
rápido, uma produtividade maior nas reuniões. Ela já vinha pronta, feita por alguém mais gabaritado ("GA is preparing a checklist...which is the one... we have/given to you", grifos nossos), ou seja, ela seria a verdadeira, a única versão possível. Não existe a prática, mas sim uma demonstração, mais uma receita a ser seguida sem espaço para discussão. Da mesma maneira, em momentos de outras reuniões as multiplicadoras parecem tomar as lições dos professores:

\section{Excerto 12:}

PM2: so/ BEArin this in mind/ bearing this in mind/ what was the first?/ what was the concrete experience phase that you have P8: teacher talks to a student (...)

Alguns Ps: $\quad$ have (...) Ps (...)[uma professora lê as instruções escritas numa das tiras das aulas]

PM2: what was the context? the relevance

Alguns Ps: shopping

P9: $\quad$ shoppingl shopping

PM2: the relevance/ to the student?

P10: they need (...)

P9: the shopping

$\mathrm{P} 4$ : the shopping

O diálogo acima nos remete ao estilo behaviorista de estímulo-resposta, ligado também ao discurso de QT. Assim, os professores são treinados a dar as respostas desejadas pelos multiplicadores, as quais que quase sempre são resumidas em afirmações simplistas como no trecho sobre a relevância de ir fazer compras, em que os professores dizem que a língua estudada é importante para o aluno pois todo mundo faz compras, bem como todo mundo fala sobre seus sonhos, ou todo mundo pede comida em um restaurante, etc...

Como as aulas apresentadas nas reuniões sempre podem ser encaixadas na lista de procedimentos dada, a reflexão é sempre no sentido de avaliar positivamente os atributos da aula no ciclo. Como todos eram observados (pelos colegas ou pelos membros da gerência presentes), era importante que sempre fossem ressaltados os aspectos positivos das aulas. Essa vigilância se aproxima do modelo do panóptico discutido por Foucault (1987/2000). 
O Panóptico de Bentham é um tipo de arquitetura de prisões onde as celas são construídas compondo um formato de anel, na periferia, enquanto no centro há uma torre. Como as celas possuem janelas vazadas que se abrem para o centro do anel, alguém que estivesse nas celas, fosse um doente ou um condenado, poderia ser sempre observado por um guarda que estivesse na torre, pelo efeito da contraluz. Esse tipo de organização arquitetural demonstra como o exercício do poder pode ser aperfeiçoado, pois induz no detento "um estado consciente e permanente de visibilidade que assegura o funcionamento automático do poder" (Foucault, op. cit.:166). O detento não estaria mais protegido pela escuridão da masmorra, e ficaria muito mais vulnerável, pois todos os seus movimentos poderiam ser percebidos.

Já numa instituição moderna de ensino como a estudada, o efeito panóptico pode ser percebido na construção de algumas filiais e na disposição dos professores nas reuniões (bem como dos alunos em sala de aula). Na filial observada, por exemplo, havia dois andares além do térreo (onde se localizava a secretaria e a sala da gerência). Da secretaria era possível ver as rampas e metade das classes dos andares acima, e bastava que se andasse para o outro lado do prédio que se teria uma visão da outra metade. Dessa maneira, era possível o controle de entrada e saída dos alunos, tanto por parte dos secretários como por um pai que aguardasse seu filho, por exemplo. Se um professor esquecesse algum material na sala de professores, ele seria flagrado ao sair de sua sala e descer a rampa para apanhá-lo.

Nas filiais mais novas, essa "transparência" era mais evidente, pois não havia paredes que separassem as salas da gerência, apenas uma janela de vidro. Esse aproveitamento do espaço promoveria não só a vigilância mútua (gerentesecretários, secretários-gerentes, pais-gerentes, etc...), mas a noção de uma empresa moderna e eficiente, aberta ao público, sem recear estar à mostra a todo momento. Durante as reuniões, os professores ficavam em um círculo ou semicírculo, podendo ser observados a todo instante por algum colega ou gerente, e vice-versa. 
Ao terem as aulas avaliadas positivamente, todos estariam satisfeitos: a gerência, porque os professores estaria produzindo; os PMs, pois os professores teriam aprendido; e os professores, pois teriam um modelo "correto" de aula e estariam demonstrando a seus gerentes quanto estavam engajados.

\section{Conclusão}

Através da análise de recortes feitos nas sessões de ER da instituição, concluímos que o controle do discurso é feito por intermédio da estrutura do projeto, da montagem das sessões e da influência das posições subjetivas ocupadas pelos PMs, além daquela exercida pela gerência da filial. Enquanto os PMs são um elo de ligação entre a instituição e o corpo docente, fazendo que os objetivos da mesma sejam melhor recebidos e internalizados, a gerência funciona de maneira autoritária, inibindo qualquer tipo de manifestação contrária ao projeto durante as reuniões. Ao mesmo tempo, as sessões são montadas de maneira a conduzir a produção de sentidos para os propósitos institucionais, causando a impressão de que é o corpo docente quem produz os saberes. $\mathrm{Na}$ realidade, esses saberes (visíveis nas reuniões) são impostos pela instituição, e a discussão acerca da sua validade é minimizada não só pelo tempo que é devotado a ela, como também pelo tipo de questionamento que é feito.

O momento no qual nosso corpus foi coletado reflete uma tentativa de construir o conhecimento idealizado pelo ER, conhecimento que deveria partir de uma conscientização do próprio professor sobre as vantagens de uma nova abordagem de ensino. As sessões aqui analisadas acontecem num período em que não mais as crenças dos professores ou as teorias de aprendizagem são discutidas, mas um modelo de aula ideal. Esse modelo em nenhum momento é avaliado pelo professor como ideal, pois o que ele faz durante as reuniões é enumerar seus pontos positivos e negativos. Ao professor, ou mesmo ao PM, não é dada a autonomia para discordar do tipo de aula que lhe é imposta, pois esta já foi instituída como a melhor. 
Apesar de o controle parecer absoluto, os professores produzem saberes. Essa produção ocorre através do silêncio durante as reuniões, dos comentários depois das mesmas, ou mesmo quando os professores adaptam seus planos de aula para melhor demonstrar que estão de acordo com o discurso institucional. A resistência só não é externalizada durante os encontros porque o corpo docente parece saber que não deve/não pode confrontar a instituição. Uma outra possível razão para esse tipo de atitude talvez esteja no fato de que o professor também é constituído por outros discursos, vivendo, assim, um conflito, como discutiremos no próximo capítulo. 


\section{CAPÍTULO 4:}

\section{O Discurso dos Professores}

Para complementar nossa reflexão, dedicaremos este capítulo ao discurso dos professores. Encarregados de colocar em prática as idéias do projeto de ER e o novo modelo de aula proposto pela instituição, os professores exercem importante papel em nossa pesquisa.

A primeira coisa que nos chamou a atenção ao relermos as entrevistas feitas com os professores foi uma aparente homogeneização dos discursos. Era como se todos possuíssem uma resposta pronta para perguntas do tipo "O que é o Ensino Reflexivo?" ou mesmo uma idéia similar das qualidades necessárias para ser um bom professor. Com o decorrer das entrevistas e em outros momentos da pesquisa, contudo, pudemos notar alguns pontos de conflito nos enunciados, que nos levam a outros sentidos, outras impressões dos professores acerca da sua prática profissional e do momento vivido pelo corpo docente na instituição durante o período em que a pesquisa foi feita.

Assim, neste capítulo, procuraremos demonstrar que essas contradições estão ligadas à fragmentação das identidades dos professores e à pluralidade de vozes que constituem sua fala. Discutiremos alguns problemas relacionados com as condições em que ocorreram as entrevistas, além de fazer algumas considerações a respeito do engajamento e da aceitação do projeto. Concluiremos nossa discussão com uma análise da dualidade ER/QT a partir da influência dessas diferentes vozes encontradas no discurso dos professores, tanto durante as entrevistas como em outros momentos da pesquisa.

\section{As entrevistas}

Como foi explicitado na primeira parte de nosso trabalho, todos os professores informantes eram conhecidos da pesquisadora e seus colegas de trabalho havia pelo menos quatro anos no momento das conversas, o que deveria propiciar uma 
maior abertura para questionamentos ou para a própria exposição de idéias. Contudo, alguns fatores contribuíram para que as entrevistas parecessem um pouco formais a princípio. Entre eles estavam o local das entrevistas e as múltiplas funções exercidas pela entrevistadora no momento da coleta do corpus, conforme discutiremos a seguir.

\subsection{O local das entrevistas}

Como não era possível que os professores e a entrevistadora se encontrassem em outro lugar, uma sala de aula da própria instituição foi usada como ponto de encontro. Apesar de as entrevistas estarem sendo feitas com o conhecimento da gerência, o receio de estar falando algo que fosse contrário ao pensamento da instituição parecia fazer com que os professores se sentissem reprimidos, pouco à vontade para se expressar. Se alguém por engano entrava na sala, a conversa era interrompida, como se somente a portas fechadas os professores tivessem a certeza de que não estavam sendo observados.

Esse sentimento nos remete a Foucault (1987/2000) e à idéia do aparelho disciplinar perfeito que poderia fazer que um olhar fosse o suficiente para o controle permanente sobre os acontecimentos. Tal olhar advém do poder disciplinar:

O poder disciplinar é com efeito um poder que, em vez de se apropriar e de retirar, tem como função maior "adestrar"; ou sem dúvida adestrar para retirar e se apropriar ainda mais e melhor.(op. cit.:143)

Assim, a aceitação da gerência da filial para que as entrevistas ocorressem ali poderia funcionar como um elemento de controle invisível, a partir do qual ao se permitir o uso da palavra, a instituição acabasse por retirar a própria liberdade de expressão do professor. De uma maneira ou de outra, conscientemente ou não, ele estaria influenciado pelo olhar da instituição, quando não pelo seu próprio olhar controlador e de auto censura. Seria ético que alguém, exercendo uma função numa determinada instituição, fizesse críticas a esta dentro do seu território? Essa autocensura acaba por determinar padrões de comportamento nos sujeitos da pesquisa 
e influenciar o comportamento durante as reuniões, em especial as que são presenciadas pela gerência da instituição. Vejamos o excerto seguinte.

\section{Excerto 1:}

E: e qual/ quais você acha ahh/ quais você acha que são as conseqüências do projeto/ onde é que a instituição quer chegar com o projeto

P2: a XXX?

E: hum hum

P2: as conseqüências do projeto// [risos e suspiro]

E: aliás eu não vou mencionarl o nome da instituição também não é mencionado [risos, a professora demonstra se sentir acanhada]

P2: [sorrindo] certo/ não/ eu acho que a gente/ a instituição quer chegar numa ahh/ numa...

Nesse trecho percebemos que P2 não se sente confortável para responder o que seria uma das primeiras perguntas da entrevista. Num primeiro momento, certificase que estão falando da escola ("a XXX?"), talvez não porque não soubesse, mas como estratégia para pensar melhor em uma resposta. O suspiro e o riso parecem ser compreendidos pela entrevistadora, que nesse momento solidariza-se com a posição delicada da professora, pois $\mathrm{P} 2$ pode vir a fazer um comentário negativo a uma PM (a pesquisadora, que se desdobra na função de PM, representa também a voz da instituição).

Para deixar P2 mais à vontade, a pesquisadora reforça (como já havia feito no começo da entrevista) que nenhum nome, nem mesmo o da instituição seria citado ("aliás eu não vou mencionar/ o nome da instituição também não é mencionado"). Ao responder, P2 assume a posição de uma professora ideal (para a escola), pois não afirma que não só a instituição deseja algo, mas "a gente", ou seja, o grupo de professores também partilha da mesma opinião, como se houvesse um consenso em torno do projeto.

\subsection{A fragmentação das identidades do pesquisador/ pesquisado}

Em nosso contexto, a pesquisadora é uma observadora participante, não só ao atuar nas entrevistas como também durante as reuniões gravadas em vídeo. Swann (in 
Graddol, Maybin \& Stierer, 1994) ${ }^{10}$, ao discutir a observação e coleta de dados em ambientes educacionais, observa que tanto o pesquisador como os instrumentos usados para a coleta de dados interferem no ambiente estudado, o que deve ser sempre levado em consideração numa análise. Assim, as múltiplas funções da pesquisadora no ambiente observado devem ser consideradas na análise do corpus, pois suas diferentes posições de sujeito produziram sentidos muitas vezes contraditórios nos entrevistados, como vimos acima.

Como descrito no Capítulo 1 (página 7), a pesquisadora exercia a função de professora na instituição estudada. Além disso, estava temporariamente no cargo de professora multiplicadora, ou seja, ocupava uma posição mais privilegiada na estrutura da escola que a dos demais professores. Não bastasse isso, era vista como uma aluna de pós-graduação de uma conceituada universidade, razão pela qual parecia ser respeitada intelectualmente. Isso nos remete à pluralização de identidades em constante jogo no universo discursivo (Hall: 2000).

Hall (op. cit.:7) sustenta que o constante deslocamento dessas identidades, ou a "crise de identidade", faz parte de um processo em que existem três diferentes concepções de identidade: a do sujeito do lluminismo, do sujeito sociológico ${ }^{11}$ e do sujeito pós-moderno, que é enfatizado em nosso contexto.

\footnotetext{
${ }^{10}$ Para esta pesquisa, foram seguidas algumas orientações do autor para as gravações em áudio, como a utilização de um modelo de gravador com microfone embutido para diminuir a sensação de estranheza provocada pelo aparelho. Para a gravação em vídeo das reuniões, o desconforto pela presença da câmera foi diminuído graças ao tamanho da sala de aula e à cumplicidade que a pesquisadora tinha com os outros professores, já que ela havia salientado que suas ações e voz também eram objeto da gravação, e não apenas a fala dos professores. De qualquer maneira, o início das conversas era sempre informal, fazendo que a presença desses aparelhos fosse minimizada, em especial nas reuniões, em que após os primeiros momentos a gravação parecia não acontecer tamanho o número de comentários a serem feitos. Já o gravador acabava por ser mais visível no contexto usado, chamando a atenção do entrevistado, que muitas vezes chegava a perguntar se "poderia" fazer algum comentário.

${ }^{11}$ Tanto o sujeito do Iluminismo quanto o sociológico fazem parte do que é o chamado sujeito moderno. O primeiro tem por base o nascimento do indivíduo soberano, do ser humano como uma pessoa centrada, única, que não é transformada de acordo com o seu desenvolvimento. A partir desse ser racional e científico, poderíamos compreender a história humana. Já o sujeito sociológico "refletia a crescente complexidade do mundo moderno e a consciência de que esse núcleo interior do sujeito não era autônomo e suficiente, mas era formado na relação com outras pessoas importantes a ele" (Hall, op.cit.:11).
} 
O pós-modernismo trouxe à tona uma identidade que está longe de ser fixa, assumimos identidades diversas em momentos distintos, passando por processos de identificação temporários. Laclau (apud Hall, op. cit.:16), propõe que as sociedades atuais são caracterizadas pela diferença e "atravessadas por divisões e antagonismos sociais que produzem diferentes posições de sujeito". Assim, à medida que os indivíduos se defrontam com determinadas situações vão se articulando e se posicionando, mas sua identidade permanece aberta.

Esse tipo de relação nos remete à $A D$, segundo a qual o sujeito é visto a "partir de lugares socialmente determinados" (Indursky, 1998:114). O sujeito é interpelado pela ideologia e se identifica com uma determinada formação discursiva, constituída de "enunciados discursivos que representam um modo de relacionar-se com a ideologia vigente, regulando o que pode e deve ser dito, mas também o que não pode, não deve ser dito" (Indursky, op. cit.:115). Assim, o sujeito está filiado a diferentes formações discursivas, ainda que os limites destas não sejam estáveis ou definidos.

Em nosso contexto, essas identidades atuavam contraditoriamente, pois, ao mesmo tempo que um professor poderia ver a pesquisadora como sua colega, sentindo-se mais propenso a comentários críticos acerca dos acontecimentos da escola, a posição de PM trabalhava de maneira contrária. Como sentir-se à vontade para expor seus pensamentos quando se está falando com alguém que tem um contato maior com sua gerência? A pesquisadora, na função também de PM, não poderia aproveitar a oportunidade de alcançar uma posição hierarquicamente mais vantajosa, usando os comentários dos professores contra eles mesmos? Enfim, qual seria a validade de uma professora pesquisar o contexto em que estava tão envolvida?

Da mesma maneira, a própria pesquisadora sentia essa diversidade de posições atuando juntas, pois quando estava na posição de entrevistadora tinha que trabalhar para que os professores pudessem criticar as reuniões e atitudes das quais ela fazia parte como elaboradora. Ao preparar uma reunião, a porção $P M$ da pesquisadora 
deveria levar em conta o discurso da instituição e os objetivos do projeto, não suas críticas ao mesmo. Nesse sentido, ela era detentora da palavra e estava autorizada a utilizá-la. Como professora da instituição, porém, deveria colocar em prática os pressupostos do ER, enfrentando as mesmas dificuldades que os demais professores.

Enfim, essa multiplicação de posições de sujeito está em constante atuação tanto na realidade da pesquisadora como na dos colaboradores, e significa à medida que os sentidos são produzidos, conscientemente ou não. Isso porque, a despeito de nossa vontade, nem sempre temos controle sobre nosso dizer. Há sempre a possibilidade de sermos traídos por nossa pretensa objetividade, deixando escapar algum outro sentido.

Essas dúvidas acerca dos papéis representados estiveram certamente presentes durante as entrevistas. Tanto que P1 chegou a comentar alguns dias após sua entrevista que não esperava que fosse questionada sobre a validade do projeto, e sim a respeito de sua organização, como se a entrevista fosse uma espécie de verificação de conceitos por meio da qual a pesquisadora, na posição de PM, pudesse perceber quanto cada um havia aprendido. Em outros excertos, os professores mostravam que estavam a par do discurso educacional que permeava as reuniões, como vemos no excerto a seguir.

\section{Excerto 2:}

P2: ... a pessoa acha que tá aprendendo/ numa instituição você tem a parte financeira logicamente e a parte/ idealística né/ da coisa/ vamos dizer assim/ idealística seria você aprender o inglês mesmo/ conseguir/ mudar o comportamento né [a entrevistadora concorda] de alguém/ pela educação/ ó que chiquel citar Vygotskyl

E: él ficou bonito agora

P2: ficou bonitol não ficou?l ficou legal [risos]/ eu tô mesmo falando brincando/ mas éée/ é isso/ aprender inglês realmente de uma maneira agradável [a entrevistadora concorda] certo/ ... 
No excerto acima, vemos que P2 tenta estar de acordo com o discurso educacional da instituição e procura a aceitação da entrevistadora ("ó que chique/ citar Vygotsky"), além de fazer menção a idéias discutidas durante uma das reuniões ("mudar o comportamento de alguém pela educação"). É importante salientar que a entrevista com P2 ocorreu logo após uma das sessões do projeto, o que parece influenciar seus enunciados. Além disso, como aluna de pós-graduação, deve estar ciente das diversas teorias sobre educação, o que fica claro quando menciona Vygotsky.

P2 não só cita o autor como explicita a citação em seu enunciado. Isto nos leva à discussão sobre a teoria polifônica da enunciação ${ }^{12}$ (Ducrot, 1987) que postula que o falante não é um sujeito único. Em um enunciado estaria presente o locutor, que "é, no próprio sentido do enunciado, apresentado como seu responsável, ou seja, como alguém a quem se deve imputar a responsabilidade do enunciado" (Ducrot, op. cit:182), e o(s) enunciador(es), "que são considerados como se expressando através da enunciação, sem que para tanto se Ihe atribuam falas precisas; se eles 'falam' é somente no sentido em que a enunciação é vista como expressando seu ponto de vista, sua posição, sua atitude, mas não, no sentido material do termo, suas palavras" (Ducrot, op. cit.:192).

Assim, no caso do excerto 2, P2 seria o locutor, enquanto Vygotsky poderia ser considerado um dos enunciadores, assim como outros autores que vêem na educação a chance de mudança (ou mesmo os PMs, pois eles discutiram o assunto em suas reuniões). Porém, o fato de P2 explicitar que estava citando Vygotsky sugere que ela estava consciente acerca deste outro enunciador.

Se assumirmos que P2 está usando uma reformulação que mantém o sentido da fala de Vygotsky, estaríamos diante de um caso de discurso direto livre sem aspas (Maingueneau, 2002), pois a própria fala de P2 estabeleceria a separação entre seu discurso e o do outro ("ó que chique/ citar Vygotsky"). Isso não descartaria a

\footnotetext{
${ }^{12}$ Ducrot, conforme Brandão (1991), retoma o conceito de Bakthin e opera-o num nível lingüístico.
} 
possibilidade de $\mathrm{P} 2$ desejar mencionar o autor para que fosse creditado respeito à sua fala, o que nos levaria a Foucault e à necessidade da autorização da palavra discutida no Capítulo 3 (página 56).

Contudo, P2 deixa escapar sua preocupação com a qualidade ao mencionar a parte "financeira" da instituição, que em sua fala é apresentada até antes da "idealística", ou seja, aquela que abrangeria a educação. Essa preocupação também é exteriorizada quando P2 menciona uma maneira idealizada de aprender inglês, que seja "agradável", como se fosse possível garantir a satisfação do aluno. Nesse caso, estaríamos diante da influência de outro discurso, o da QT.

Esse excerto é um exemplo das diferentes posições de sujeito ocupadas pela entrevistada. Ao usar Vygotsky, ela estaria ocupando o lugar de uma docente e de uma aluna de pós-graduação conhecedora de teorias educacionais. Ao usar um vocabulário informal ("ó que chique"), procurando a aceitação da entrevistadora, ela estaria ocupando a posição de colega, de uma pessoa com quem se tem intimidade. Já a menção às preocupações financeiras da instituição implica a posição de professora engajada na escola (pois se preocupa com o cumprimento das metas). Enfim, sua fala demonstra ser múltipla, heterogênea.

Em outra entrevista, P4 insinua que precisa do aval da entrevistadora para se expressar mais livremente.

\section{Excerto 3:}

E: e como é que o professor pode colaborar para o projeto

$\mathrm{P} 4$ : comol não entendi

E: assim/ colaborar para que o projeto dê certo

P4: pode falar? [rindo]

E: pode

P4: [as duas estão rindo] aí é uma coisa que eu penso desde os meus tempos de psicóloga/ é o seguintel tem gente que pensa/ tem gente que não pensal entendeul quem pensal jóial quem não pensa amigal nem com britadeira viu// e pode ter cinco ou cinqüenta anos [rindo muito] e a tentativa do projeto é justamente essa/ é ajudar as pessoas que não tem 
facilidade ou não tem hábito/ ou que não tem assim JElto de reflective/ ah reflective/ entendeu

"Pode falar?" pode estar motivado tanto pelo fato de as duas estarem sendo gravadas, como pelo desejo de falar algo que não é o esperado, não está de acordo com a própria proposta do ER, que é promover uma mudança nos conceitos dos professores. Ao dizer que as pessoas que não são questionadoras não pensarão "nem com britadeira", ela demonstra que não acredita que a mudança de conceitos possa acontecer. Nesse momento, a entrevistadora é sua "amiga", ou seja, P4 responde à pergunta como alguém que tem liberdade para falar o que pensa, não apenas como uma professora engajada.

O riso tanto de P4 como da entrevistadora denota o conflito provocado pelas identidades em jogo. A entrevistadora, enquanto pesquisadora, procura avaliar criticamente o projeto em que ela mesma é organizadora, como PM. P4, por sua vez, ao mesmo tempo que parece não acreditar que a mudança seja possível, menciona que o projeto "tenta" ajudar as pessoas que não têm o mesmo nível de reflexão que o seu.

Esse tipo de contradição, assim como a dualidade aceitação/ resistência ao ER ou mesmo a simplificação do que é ser um bom/ mau profissional, é recorrente nas entrevistas e reflete o conflito vivido pelos sujeitos desta pesquisa. Nos excertos seguintes, discutiremos a presença de outros discursos na fala dos professores e gerentes, bem como algumas contradições presentes nos recortes.

\section{A dualidade Ensino Reflexivo/ Qualidade Total}

Para analisar os excertos selecionados, é necessário ter em mente que não estamos diante do "sujeito intencional, dono de seu dizer" (Infante, 1997:1, grifo do texto original) postulado pela Lingüística tradicional, que vê a língua como homogênea e como um objeto artificial, o que tornaria possível trabalhar cientificamente o fenômeno da linguagem. Conforme essa perspectiva, poderíamos encontrar apenas na materialidade lingüística todos os sentidos produzidos pelos enunciados, sem 
que estes fossem passíveis de outras interpretações de acordo com seu contexto sócio-histórico. O sujeito seria, por conseguinte, dotado de tal clareza ao se expressar que seria improvável que fosse malcompreendido.

A concepção da $A D$ é aquela que vê o indivíduo como um ser heterogêneo, multifacetado. Por trás de um sujeito aparentemente único e coerente, está o sujeito que é afetado pela ideologia e pelas formações discursivas às quais pertence, como vimos nos excertos anteriores, nos quais P2, P4 e a entrevistadora assumem posições de sujeito diversas.

\section{$2.1 \mathrm{O}$ (não)engajamento}

Uma das contradições encontradas na fala dos professores diz respeito ao seu engajamento no projeto. O engajamento, como já salientado anteriormente, seria um dos requisitos da gerência de Qualidade Total para que o sucesso da missão de satisfazer os clientes fosse alcançado e o número de alunos aumentado, como vimos na fala da gerente. Isso causa um certo estranhamento nos professores entrevistados, que não se consideram parte do projeto de QT, mas sim do projeto de Ensino Reflexivo como objetivo educacional e de cunho qualitativo. Eles vêem o ER como parte de sua visão do que é ser um bom professor, e não como meta numérica de alunos a ser alcançada.

\section{Excerto 4:}

$\mathrm{E}$ : como você explicaria o que é o reflective teaching/ ou o reflective learning para um professor assim que acabou de entrar aqui na XXX [ a entrevistadora diz o nome da escola]/ na instituição

P1: olha/ eu diria que é umm/ sistema pelo qual/ o professor dá a aula delel como ele acha que ele é instruídol seguindo oos princípios e depois/ ele vai analisar o que ele fez/ o que deu certo/ o que não deu certo/ e aí ele vai corrigindo/ nél se ele viu que não deu certo essa parte/ esse vídeo/ esse jogo que ele deu/ então ele vai analisar o que que foi que não deu certo/ porque que a atividade não deu certo/ e daí ele vai corrigir/ se deu certo/ aí ele vai poder usar mais uma vez/ na realidade EU AACHOI que é uma coisa que você já fazia/ que todo profissionall assim que se prezel que já fazia mas num tinha nome/ agora chama reflective teaching/ reflective learning/ seria por/ mais para o aluno/ 
Ao ser perguntada sobre o que é o projeto, P1 reforça o aspecto técnico do mesmo, como um dispositivo a ser usado em favor de uma reflexão sobre a prática de aula ("um sistema pelo qual o professor dá a aula... como ele acha que é instruído"), mencionando a reflexão baseada no próprio ciclo de aprendizagem experimental. Porém, ao dizer que todo profissional "que se preze" deveria fazer esse tipo de questionamento, P1 deixa escapar uma crítica da qual se depreende que o projeto não a teria auxiliado nesse processo, pois a reflexão já fazia parte de sua prática. Ao mesmo tempo que o "sistema" (o ER) é bom, pois proporciona questionamento, ele não é a origem do mesmo, e sim apenas a constatação de que a reflexão já existe.

É interessante que, ao mudar sua perspectiva para falar do projeto, P1 chega a aumentar o seu tom de voz ("EU AACHO"), como se após uma resposta coerente sobre como se daria o processo entrasse a ressalva de que, na realidade, ele em nada havia alterado a sua maneira de agir em sala de aula ("é uma coisa que você já fazia").

Esse sentido ficou evidenciado na fala de P1, pois, ao ser questionada a respeito do ER ela sempre fazia questão de salientar seus aspectos positivos, sem contudo deixar de exprimir alguma opinião contrária ao que estivesse sendo feito. Assim, ora P1 assume a identidade de professor "ideal" aos olhos da instituição (pois é reflexiva e concorda com o projeto), ora assume o papel de professor resistente (para a instituição, pois para o corpo docente ela seria vista como "crítica").

\section{Excerto 5:}

P1: bom eu acho que pro professorl que entral é uma coisa boa/ porque você começa a pensar sobre o que você fez/ você pode ahh/ aí refletir/ você pode ler livros sobre aquilo/ assim fica vamos dizer/ uma coisa mais organizada/ talvez já tál já fazia mas não era uma coisa assim/ tão programada/ tão sistemática/ então eu acho que PRO professorl eu acho que tem sido bom/l pro alunol o professor chamando atençãol mostrando as coisas TAMBÉM em si é uma boa coisa

E: hum hum/ você acha que oo/ que o aluno tem percepção sobre o que tá acontecendo no projeto

P1: eu acho que o aluno tem percepção/ ou pelo menos não todos os alunos/ um ou outro deve/ que tá mais interessado/ esse/ talvez esteja/ ahh vamos 
dizer ciente do que é isso/ e eu acho que aproveita porque/ pelo jeito de você melhorar (p..) o seus métodos/ o aluno/ também né/ por tabela o aluno também sai aproveitandol AGORA que eles estejam NOTANDO alguma coisa eu acho que nãol assim

Novamente P1 diz várias vezes que o projeto é bom, porém faz a ressalva de que ele é bom para quem está entrando na instituição, e não para todos (pois ela fazia parte do grupo que não necessitava do projeto para que houvesse reflexão). Da mesma maneira, o projeto é bom para os alunos "por tabela", ou seja, por uma coincidência natural, estando implicada a idéia de que, se o professor soubesse o que estava fazendo, o aluno, conseqüentemente teria vantagem. Ao mesmo tempo, e mais uma vez o aumento de voz indica discordância, P1 acaba assumindo que o aluno não sabe o que está acontecendo, isto é, não percebe melhora, seja na aula, seja em seu aprendizado.

Tanto no excerto 4 como no 5, P1 muda o sentido de sua fala. No excerto 4, eleva tom de voz em "EU AACHO...", enquanto no excerto 5 eleva em "AGORA". Ao serem interpretadas levando-se em conta essa elevação do tom de voz, suas palavras têm a mesma conotação da conjunção adversativa "mas". Ou seja, P1 usa sua fala de maneira argumentativa, apresentando duas afirmações distintas. No excerto 4, aparece a idéia de que o ER que ajuda o professor a fazer uma reflexão, idéia que é refutada pelo fato de que, "na realidade", o professor já refletia anteriormente. Já no excerto 5, P1 diz que o aluno percebe o que está acontecendo, para depois dizer que eles não notam a diferença.

Ducrot (1987: 180-181) afirma que, no caso da conjunção "mas", fica fácil perceber a presença de mais de um enunciador em uma fala. Isto porque o autor não pode ser considerado o responsável por duas afirmações distintas. A segunda afirmação (a idéia de que o professor já refletia e de que os alunos não notavam a diferença) seria, conforme a proposta de Ducrot (op. cit.), mais provavelmente do locutor (P1), enquanto as outras pertenceriam a outros enunciadores (por exemplo, as PMs, a gerência). 
Um outro ponto a ser destacado nesse excerto é a posição do aluno. Se grande parte da reflexão está centrada no professor, o aluno, por sua vez, faz papel de objeto. Amarante (1998: 169) discute o papel do aluno em sua pesquisa sobre o discurso da avaliação:

Através da utilização do pronome pessoal de terceira pessoa do singular ou do plural e, também, através do uso do artigo indefinido (...), os aprendizes são tomados como grupo, cuja identidade não é marcada pela diferença, mas revelada na determinação de sua indiferenciação. O aprendiz é, portanto, objeto, entidade a que uma história pessoal e social é negada, pois sua história é aquela de todos os demais aprendizes.

Assim, não existe uma preocupação com a heterogeneidade em sala de aula, fato que vai contra o próprio discurso acadêmico, que busca uma maior atenção às necessidades dos aprendizes como indivíduos. O grupo de alunos é visto como uma massa homogênea que receberia a informação da mesma maneira, "por tabela", como se a aula fosse mais importante para o professor, pois seu resultado não atingiria os aprendizes ("AGORA que eles estejam NOTANDO alguma coisa eu acho que não", grifos nossos). Em nosso contexto, ocorre o mesmo tipo de referência (" o aluno também sai..." e "que eles estejam NOTANDO..."). Todos os alunos são vistos como tendo as mesmas reações (de alunos interessados ou de desinteressados) e não há preocupação explícita de se adaptar os planos de aula para a diversidade.

$\mathrm{Na}$ realidade, os conflitos presentes nos enunciados dos professores estão ligados a dois discursos principais que se destacam em suas vozes: o discurso educacional e o discurso neoliberal de QT. Para melhor organizar os excertos, estaremos focalizando esses dois discursos em separado, mas tendo em mente Pechêux (1997:23), que nos chama a atenção para o fato de que um enunciado pode fazer parte de "uma rede de relações associativas implícitas", ou seja, um mesmo enunciado está repleto de outros enunciados, o que faz com que ele se torne uma fala múltipla. Dessa maneira, ao falar nos relacionamos a outros enunciados e 
outros sentidos que gerarão significados diversos se analisados a partir das suas condições de produção. A nossa divisão, portanto, é apenas didática.

\subsection{O discurso educacional}

Dado o tema de nossa pesquisa, perceber como o discurso educacional está presente na fala dos professores poderia ser considerado óbvio. Contudo, o que nos intrigou não foi o discurso educacional em si, mas a maneira como ele se apresenta. O que é interessante na fala dos entrevistados é que eles usam o discurso educacional (não necessariamente conscientes disso) tanto para provar seu maior engajamento no projeto como para demonstrar seu conhecimento, assumindo a identidade de um professor ideal, aquele que se aprimora e está em contato com as últimas tendências educacionais.

\section{Excerto 6:}

P4:...ensinar é muito mais do que isso/ nél quando você está no papel de professor com alguém/ não importa se ele é criança/ adolescente ou adulto/ não importa que matéria você está usando/ você está sendo um fator modificador nal na personalidade do cara se você pensar bem...

\section{Excerto 7:}

P4: ...isso/ então porque o professor/ não importa qual matéria / qual faixa etária ele esteja ensinando/ ele é um fator modificador na vida do aluno/ né/ então eu acho que o reflective/ vem/ é/ é a essência disso/ porque você tem que estar sempre questionando/ não é só o que você está ensinando/ mas que papel você está tendo/ né (num mundo seu)

Esses dois momentos da fala de P4 nos remetem a Paulo Freire (1997) que discute a pedagogia da autonomia e insiste na reflexão crítica sobre a prática do docente, além do papel da educação como forma de intervenção no mundo. Em sua visão, não só o conteúdo a ser ensinado pode modificar o aluno, mas a educação pode funcionar tanto para reproduzir a ideologia dominante como para desmascará-la. Ao 
assumir que não existe neutralidade na educação, o professor veria que faz muito mais do que a simples transferência de conhecimento. P4 demonstra que é consciente do seu papel como modificadora ("ensinar é muito mais que isso"), e parece ir além, pois consegue ver como o ER se encaixa nesse pensamento ("eu acho que o reflective/ vem/ é/ é a essência disso").

Nesse sentido, P4 demonstra que está de acordo com a proposta do ER. Ao mesmo tempo, essa demonstração pode significar que seu conhecimento pode ser usado para influenciar e modificar os conceitos apresentados pelo ER ou mesmo aqueles advindos da QT. Essa idéia faz retomar a questão da produção de saber discutida por Foucault (1979/2000:8), que postula que nem sempre o poder age como força repressiva, mas também produz saber e discurso. Isso garante que P4 e os demais professores sejam capazes de reconhecer suas dificuldades e se adaptar ao discurso da instituição para que seu trabalho dentro da escola não seja prejudicado. Porém, sua reflexão não está limitada à restrita pauta discutida nas reuniões.

Pessoas muito "críticas", segundo a gerente, não eram ideais para ser PMs. A função necessitava alguém engajado, que tivesse bom relacionamento com os professores e demonstrasse interesse no bem estar da escola acima de tudo. A própria pesquisadora já havia sido apontada como uma pessoa crítica demais antes de se tornar professora multiplicadora. Quando adequou a sua fala aos moldes da instituição, é porque já havia "amadurecido", estava "pronta para desempenhar este importante papel"13. Como vemos, amadurecimento, nesse caso, pode ser interpretado como aceitação do status quo.

Por vezes, demonstrar conhecimento do discurso educacional era também uma forma de conseguir reconhecimento, deixando patente para a instituição (nesse caso representada pela PM) a qualificação profissional, como vimos no Excerto 2, em que P2 ressalta ter mencionado Vygotsky e a importância da mudança pela educação.

\footnotetext{
${ }^{13}$ Palavras da gerente da filial.
} 
Em um outro momento, P2 acaba por confundir-se ao tentar verbalizar os novos conceitos:

\section{Excerto 8:}

E: o que você acha que poderia ser melhorado

P2: eu acho que as falhas/ vai tá/ vai tá justamente nessa parte que você tá scaffolding [a entrevistadora concorda] em que vai ter a activel ahh reflective observation/ active conceptualization/ and so on/ el el so on [faz referência novamente ao fato de que ela falou em inglês, sorrindo e um pouco envergonhada]

$\mathrm{E}:$ não/ pode falar que não tem problema

P2: por que eu acho que ter/ vai ser justamente aí/ como que cada um vai fazer isso aíl [a entrevistadora concorda] é o que eu tô falando/ é alguma coisa/ eu acho que não tá funcionandol se eles falaram prá mim que tá mais chato/ certo [a entrevistadora concorda] que eles acham que/ eles aprendem/ mas eles acham que/ tá precisando mais dinamismo

"Scaffolding", "active" (conceptualization) e "reflective observation" (andaime, conceitualização abstrata e observação reflexiva) são conceitos trabalhados em todas as reuniões e que remetem ao ciclo de aprendizagem experimental usado como modelo de aulas e à noção do papel do educador como monitor que ajuda o conhecimento a ser construído, segundo Vygotsky (in Scarcella \& Oxford, 1992:2426).

Como já mencionado, P2 é aluna regular de pós-graduação, razão pela qual falar de teorias da educação só enriqueceria sua imagem. Além disso, como sua entrevista havia sido feita logo após uma das sessões de Ensino Reflexivo, fica a dúvida se ela usa todo esse jargão para mostrar que aprendeu com a sessão (dada a presença da PM) ou se busca ser espontânea. De qualquer maneira, P2 não conseguiu incorporar o novo vocabulário à sua fala. Ela tenta participar do contexto, assumir a identidade de um professor engajado no processo de ER, mas não consegue, não parece se sentir confiante para usar o enunciado de outra pessoa.

Ao confundir os conceitos, a sua fala se torna um tanto sem sentido, até que P2 finalmente acaba por concluir que acha que não está funcionando, o que nos leva a 
crer que sua aparente confusão tenha sido provocada pela sensação de incapacidade diante do insucesso de suas aulas: a teoria parece ser insuficiente para que ela se convença da eficácia do processo.

Novamente, o aluno é visto como uma massa homogênea (se eles falaram prá mim que tá mais chato/ certo [a entrevistadora concorda] que eles acham que/ eles aprendem, grifos nossos). Considerando-se que as salas de aula podem ter até 20 alunos cada, a generalização se torna ainda mais evidente.

\subsubsection{As vozes dos professores}

Como pudemos perceber nos excertos apresentados, o professor vive um conflito: ora está inclinado a aceitar o discurso neoliberal de QT (o qual já o constitui), ora parece incomodado com a visão empresarial da escola. Esse conflito faz que ele assuma diversas identidades, diferentes posições de sujeito. Procuraremos a seguir ressaltar as diversas visões que os professores têm de seu papel na instituição focal.

Primeiramente, gostaríamos de nos remeter ao pensamento de Bakhtin (1992, 1992a) sobre a linguagem. Conforme o princípio do dialogismo, o ser humano pode ser definido pela alteridade, pois o "outro" é necessário para que eu me reconheça como pessoa. Assim, a interação entre interlocutores é fundamental, pois os sentidos são construídos através dessa produção e interpretação de enunciados.

Como vimos em nossos excertos, nas reuniões e entrevistas os professores interagem, muitas vezes criando sentidos que se misturam a outros que fazem parte de nossa memória discursiva (Brandão, 1991; Orlandi, 1999). Ao falar, temos a idéia de que somos a origem de nosso dizer, enquanto nossos enunciados estão retomando sentidos que já foram expressos anteriormente (Brandão, op. cit.; Orlandi, op. cit.). 
Construímos diálogos entre discursos, pois somos seres sociais e não individuais. Nosso discurso é composto de muitas vozes, outros discursos que estão inseridos no nosso, completando-o ou cruzando-o. Bakhtin (1992: 314, grifos do original) afirma que:

Nossa fala, isto é, nossos enunciados (...) estão repletos de palavras dos outros, caracterizadas, em graus variáveis, pela alteridade ou pela assimilação, caracterizadas, também em graus variáveis, por um emprego consciente e decalcado. As palavras dos outros introduzem sua própria expressividade, seu tom valorativo, que assimilamos, reestruturamos, modificamos.

Assim, o enunciado, que é um elo na cadeia de comunicação, passa por uma constante mudança, pois une-se a outros sentidos já existentes e que estão, muitas vezes, assimilados pelo falante. Bakhtin (op. cit.) explica que as palavras que ouvimos não são mais "neutras", como se pretende que elas sejam em um dicionário. Elas são também as palavras dos "outros" que preenchem os espaços de enunciados alheios, e são "minhas" porque estão influenciadas pelo contexto no qual as estou usando, o que as faz únicas por estarem impregnadas pelo meu sentido.

Na mesma linha, Authier-Revuz (1982) trabalha com a heterogeneidade, postulando que a materialidade lingüística do texto traz à tona marcas mais ou menos explícitas da interferência das palavras do "outro" nas minhas. Essas marcas são constitutivas pois pressupõem o discurso como produto de interdiscursos (ou seja, um discurso é sempre formado por outros discursos que fazem parte de seu inconsciente, numa acepção lacaniana), ou, quando essas marcas estão visíveis, como por exemplo através dos discursos direto e indireto, podem ser um exemplo da heterogeneidade representada. Apesar da heterogeneidade estar sempre presente, existe a ilusão de uma objetividade através da qual um interlocutor se comunicaria.

Carmagnani (1996) sustenta que o sujeito "pode até mesmo planejar o seu discurso, mas os efeitos de sentido que produzirá não serão necessariamente aqueles que 
foram previstos", pois a manifestação discursiva também depende da interpretação do papel do "outro" em sua argumentação.

Vejamos nos trechos seguintes como o professor se vê (e é visto) dentro do contexto do projeto de ER e como essas outras falas estão inseridas no seu discurso e o constituem.

\subsubsection{O professor ideal}

O conceito de professor ideal depende da posição do observador, ou seja, se ele é docente ou gerente. Para os professores, além de responsável, o professor ideal é aplicado e atingiu um estágio de reflexão privilegiado.

\section{Excerto 9:}

E: então você/bom/ se você é uma professora que você ééé/ você

P4: eu modéstia à parte eu acho que eu sou das que reflect

E: você é uma pessoa/ é uma pessoa reflective/ ahh/ e você/l agora perdi minha pergunta/ e você entra no projetol então o projeto vai bem prá você $\mathrm{P} 4$ : isto/ e você se sente super satisfeita

$\mathrm{E}: \quad$ e prás outras pessoas

P4: porque você/ você precisa comprar a idéia/ a idéia já é sua/ entendeu

E:

ela já existia antes

P4: eu me lembro numa reunião/ pode citar?/ [rindo] foi daquela quando tava juntando o atlas [menciona o nome de um livro didático que já fora usado]/ foi aquela confusão/ e eu me lembro que uma professora nossal uma professora daquela que reflect MUlto/ né/ é/ falou assim/ ah mas isso a gente sempre fez/ e a/ uma pessoa lá da chefia falou assim/ ail você está sendo resistente às mudanças [em tom sarcástico, encenando o que ocorreu e rindo depois] nél ela que não era/ ela se achou GRANdes mudanças/ olha como eu tô mudando/ eu falei não só/ você tá acordando [ambas rindo muito]

P4 é um exemplo de professor ideal, visto do ponto de vista do próprio docente: não considera que o projeto tenha Ihe trazido alguma novidade, já que "a idéia já é sua" e "modéstia à parte" ela se vê como uma pessoa reflexiva. Ao contrário, além de não precisar do projeto para refletir, ela não respeita a gerência pedagogicamente. "Ela não notou que o negócio foi sempre assim" e "você está acordando" servem como uma crítica dura à postura da gerente, além de serem falas carregadas de ironia. $\mathrm{O}$ 
riso compartilhado sugere que tanto entrevistadora como entrevistada têm a mesma opinião, possivelmente pela atitude que a gerente tem de não aceitar comentários dos professores.

No excerto 9, P4 faz uso das palavras do outro professor para demonstrar o diálogo entre as diferentes posições representadas pela instituição e pelo professor. A instituição quer a reflexão, porém não aceita crítica. Podemos notar essa posição no momento em que a professora diz já refletir antes do ER e isso é visto como resistência. Já o professor é cindido: ideal ou não para a instituição, ideal ou não para os professores. Sua identidade é fragmentada, por isso ele parece viver num conflito entre seguir o ER ou se impor diante da instituição. Se por um lado a idéia do ER "já é sua", por outro ele quer demonstrar que não precisa do projeto para auxiliá-lo ("mas isso a gente sempre fez").

Já para a gerência, o professor ideal parece ser aquele que não exprime opinião contrária à sua ou não se mostra resistente, pois dizer que "isso a gente sempre fez" produziu um sentido de resistência para o representante da gerência ("lá da chefia falou assim/ ai/ você está sendo resistente às mudanças"). Além disso, para a instituição o professor ideal vai além das expectativas, como veremos a seguir.

\section{Excerto 10:}

G: ...STILL/ I'm ahn/ an optimist/ ... I'm sharing it with you/ what's happening/ at the moment I think we've just got/I think 3000 students/ our budget is three thousand EIGHT hundred// we're not gonna reach it/ obviously// okay/ but we are doing what we canl if you are passing by the secretaria and you can answer the phone/ thank you very much/...

Ou seja, para a instituição, o professor ideal é aquele que demonstra total dedicação à empresa, fazendo inclusive outros serviços não relacionados com suas funções, como atender ao telefone ("if you are passing by the secretaria...") ou até fazer matrículas (pois durante as férias os professores eram solicitados para tal). 


\subsubsection{O professor faz demais}

Trabalhar demais sem ser remunerado ou reconhecido é uma outra idéia recorrente nas entrevistas. Todos os professores se ressentem pelo fato de que a culpa pelo possível fracasso do projeto possa recair sobre eles.

\section{Excerto 11:}

E: e você achaaa/ por exemplo/ você tá dizendo que por enquanto ahh/ o projeto não surtiu/ não teve o efeito ahh digamos/ em números/ né ...

E: como profissional/ e você achaaa/ e se o projeto não der certo/ o que/ ou se não dá certo/ se não tá dando certo/ quem você acha que está sendo responsabilizado por isso

P3: [uma breve pausa] acho que nós

E: nós os professores/ nós da filial

P3: acho que nós professores em geral

E: por que que você acha isso

P3: por que eu acho assim/ (...) um aluno/ saiu da XXX/ então quem é culpado? é o professor? é o/ é o

E: gerência

P3: gerência?/ eu acho assim/ o professor tá fazendo o máximo/ tá nós tamos tentando fazer tudo que nos é dado/ eu acho que/ ótimo/ mas se os alunos desistem geralmentel geralmente nãol mas a primeiral a primeira RAZÃO é o professor

Segundo a perspectiva de P3, ele se esforça para que o aprimoramento ocorra ("o professor tá fazendo o máximo"), considerando-se engajado no projeto. Porém, há outro aspecto do ER com o qual ele não concorda: o fato de o professor ser responsabilizado pela perda de alunos. Essa responsabilidade vem de fora, provavelmente da instituição, não de sua auto crítica, pois ele acredita que "o professor tá fazendo o máximo". Para a instituição, a "primeira RAZÃO" para um aluno desistir do curso é sempre o professor, nunca a escola.

Ao ser perguntado sobre a responsabilidade pelo insucesso, P3 não hesita em dizer "nós". Esse uso do pronome na primeira pessoa do plural nos remete à maneira como as PMs estabeleciam um vínculo com os professores durante as reuniões, conforme discutido no Capítulo 3 (página 56). Tanto que o "nós" não é compreendido pela entrevistadora. Esse "nós" se refere aos professores como parte de uma formação discursiva, ou seria o "nós" dos funcionários do instituto de 
línguas, ou até mesmo a própria instituição ? Ao esclarecer esse ponto, P3 reitera a cumplicidade existente entre ele e a pesquisadora, pois responde que o "nós" se refere ao grupo dos professores do qual a pesquisadora também faz parte. De qualquer maneira, o professor, apesar de fazer tudo que lhe é pedido, se transforma na razão do insucesso.

\subsubsection{O professor assume a culpa}

P2 não procura negar sua culpa, responsabilizando-se pelo fato de sua aula não ter dado certo.

\section{Excerto 12:}

P2: que é o meu grande problema/ eu acho que as aulas tão um pouco tãl se você nul num dosar a coisa fica um pouco meio boring/ tem que ver o que tá acontecendo/ que eu acho que eu não tôôll $\mathrm{E}$ : comprida no sentido de boring

Podemos notar que P2 é categórica: tem um grande problema ("é o meu..."), acha que suas aulas estão entediantes ("eu acho..."). A responsabilidade é do professor, pois ela diz que "se você nu/ num dosar a coisa", ou seja, a aula, isso vai causar tédio nos alunos. Para ela, o professor "tem que ver o que está acontecendo". Como ela admite que não está conseguindo identificar o problema, deixa implícito o reconhecimento de que não dá a aula de maneira correta. Sua fala produz um sentido de confissão, principalmente por não ter conseguido terminar a frase (existe uma pausa antes que a pesquisadora faça a pergunta).

Esse dado nos remete a Foucault (1988: 16-49) e sua reflexão sobre o uso da confissão como forma de poder. Ele afirma que a confissão confere ao "mestre" (no caso a pesquisadora no papel de PM) um saber que lhe permite ser "um conselheiro melhor". Por ser uma PM, a pesquisadora se posiciona em um nível de conhecimento maior que o de P2. Ao falar sobre suas possíveis falhas em relação à aula e ao projeto, P2 procura ser aceita pela PM, que nesse caso representa a voz da instituição. 
A aplicação do novo modelo de aula (o ciclo experimental) e a percepção dos alunos ("a coisa ficou meio boring") provocam diversas reações. O docente oscila entre se sentir culpado (como no caso de P2) ou não (P3). Essa sujeição é de ordem ideológica, com a escola funcionando como um aparelho de Estado (Althusser:1998). Somos interpelados pela ideologia desde que nascemos, pois ela atua sem que os sujeitos necessariamente reconheçam que estão sendo influenciados. As exceções, segundo Althusser, são os "maus sujeitos que provocam a intervenção de um ou outro setor do aparelho (repressivo) do Estado" (1918/1998:103).

Assim, quem não interfere no mecanismo de sujeição de algum aparelho de Estado, seja ele a família, a igreja ou a escola, como é o nosso caso, é considerado bom, pois está entregue à ideologia sem que haja resistência. Nos excertos acima, percebemos que esse tipo de responsabilidade é inerente à função dos professores na instituição estudada. A partir de sua existência é que eles se posicionam como bons ou maus professores reflexivos, sendo que a instituição espera que a culpa pelo fracasso do projeto seja assumida por eles.

\subsubsection{O professor racional}

A fala dos professores por vezes sugere praticidade. Apesar de seu interesse em serem bons profissionais, nem sempre estão dispostos a fazer qualquer coisa para serem vistos como tais.

\section{Excerto 13:}

P4:

vai num/ vai num/ um aumento de coisa/ ah bibliografia num sei o que/ eu olho lá naquele reflective corner e eu falo/ o pessoal tá pirando aqui/ é o que eu gostaria de fazer/ é o que todo mundo gostaria de fazer/ eu acho que quando uma pessoa quer fazer uma coisa séria a gente quer fazer sempre o melhorl nél HOWEVERI amigal eu vendi tantas horas minhas prá XXXI e

E: eu não posso dar o dobro 
P4: eu não posso dar o dobro que isso cara/ é é real/ porque na hora que eles fazem as contas deles também/ eles querem que dê lucro nél e a gente como é que fica/ então eu...

O professor internaliza a noção de produtividade e de custo-benefício advindas da QT e percebe que, por mais que esteja interessado ("quando uma pessoa quer fazer uma coisa séria a gente quer fazer sempre o melhor"), não pode esquecer que sua função é remunerada já que a instituição faz "as contas deles também", como profissional ele merece ser remunerado pelo serviço extra.

\subsection{O discurso da Qualidade Total}

No discurso que produzimos, estamos sempre constituídos pelo interdiscurso, isto é, pelas formações discursivas em que todo dizer está inserido. O interdiscurso pode ser visto como uma série de formulações já feitas a respeito daquilo que é falado, a historicidade que determina o que é relevante ou não em um determinado contexto (Orlandi, 1999:33). Como sujeitos discursivos, os professores de nossa pesquisa são um exemplo de falantes interpelados pela ideologia, nem sempre conscientes dos outros discursos que os constituem. Em seus enunciados, pudemos notar a influência desses outros discursos, como o discurso educacional (representado pelo ER e pela importância do conhecimento profissional) ou mesmo o discurso neoliberal de QT.

Entretanto, o que nos chama a atenção é o fato de os professores não parecerem conscientes do quanto a QT os influencia como sujeitos. Eles demonstram não estar confortáveis com o papel de prestadores de serviço e encontram nessa atribuição uma das causas dos problemas que vêm enfrentando:

\section{Excerto 14:}

P1: e o que eu acho também é a nomenclatura que se tem hoje em dia/ porque hoje em dia você não tem alunos/ você tem clientes/ você não dá aula/ você vende o produto [a entrevistadora ri] você gerencia/ você negocia [a entrevistadora comenta algo] você não/ né não tem alunos/ não tem mais professor/ não é uma nomenclatura totalmente diferente eu acho 
que a gente acaba esquecendo que está numa escola/ porque é uma instituição/ não é mais uma escola/ então a gente estranha um pouquinho

Ao dizer que "a gente acaba se esquecendo que está numa escola", o professor critica essa abordagem empresarial, produzindo um sentido segundo o qual o ato de ensinar nem sempre pode ser visto como algo a ser negociado ou medido. A escola tem um currículo, livros e carga horária que não podem ser negociados, e o professor se considera um educador, um especialista que sabe como facilitar a aprendizagem de seus alunos.

Colocar o aluno na posição de cliente e a aula na de produto seria, na visão de P1, confundir sua função e seu poder de decisão acerca do que deve ou não ser ensinado ("a gente estranha um pouquinho"). A escola é deslocada ("não tem alunos/ não tem mais professor"), bem como a aula ("você não dá aula/ você vende o produto"). Além de P1 estranhar o novo contexto, sua fala ("hoje em dia") e seu tom de voz diminuído exprimem uma nostalgia, como se ela tivesse saudade de outros tempos (P1 trabalhava na instituição havia 30 anos na época da pesquisa).

Apesar de não concordar com a idéia do professor como um prestador de serviço no sentido comercial da palavra, ou seja, como uma pessoa que é responsável pela manipulação e entrega de produto para que a satisfação do cliente seja atingida, o professor se sente responsável pelo atendimento das necessidades de seu aluno/ cliente.

\section{Excerto 15:}

E: hum hum/ então você diria que o reflective é poder usarl diversas técnicas contanto que você tenha um propósito e saiba explicar

P2: $\quad$ contanto que você saia feliz da sala de aula/ achando que funcionou [a entrevistadora concorda]/ que atendeu as necessidades do aluno [um leve sorriso]

De acordo com esse excerto, o ER é um instrumento usado na busca de satisfação ("usar diversas técnicas contanto que você tenha um propósito"), a qual é 
conseqüência de um atendimento adequado às necessidades do aluno. "Sair feliz da aula" equivale a atender a necessidade do aluno.

Assim, a identidade do professor está sempre oscilando entre o ser e o não ser, não importa se nos referimos ao profissional que a escola quer, o professor reflexivo que o projeto procura ou mesmo uma pessoa que é constituída pelo discurso da QT. Esse conflito advém da pluralidade de vozes que constituem o sujeito e a todas as relações sociais (Coracini, 1997).

Um outro detalhe que nos chama a atenção é a simplificação do projeto em um número de "técnicas" que devem ser usadas "contanto que" dêem certo, segundo as palavras da entrevistadora. O uso da locução conjuntiva indica que, para dar certo, o projeto nem precisaria do ciclo experimental, como havia sido enfatizado pelas PMs. Se o objetivo final era que o aluno saísse contente da aulas, outros tipos de técnicas mais simples de serem usadas poderiam ter um efeito até mais visível que toda a postura do ER. Esse enunciado é conflituoso com a própria posição de entrevistadora, já que ela é PM e responsável pela disseminação das idéias do ER. Simplificar o ER seria negá-lo ou, no mínimo, não acreditar em seus propósitos. Esse conflito decorre do fato de a entrevistadora, como já comentamos, desempenhar diferentes papéis no contexto estudado os quais constituem sua identidade.

Para chamar a atenção do aluno para o seu aprendizado, o mesmo tipo de construção é usado pela PM durante uma das reuniões de ER:

\section{Excerto 16:}

PM2: function ahh/ questions/ what other and something that is good to to point here is that/ here we could have drilling/ you can have whatever AS LONG AS you're raising their awareness/ the students'awareness/ to the relevance/ to the student/ of this social act (...)

Nesse caso, chama-se a atenção para a necessidade de o aluno reconhecer que está aprendendo. Sem esse reconhecimento, a instituição não se firma como uma 
empresa de qualidade, não tendo seu produto reconhecido no mercado de escolas de língua estrangeira. O projeto deve, acima de tudo, buscar atingir metas da empresa/ escola.

\section{Excerto 17:}

P4: olha porque junto com o projeto do reflective/ tem o projeto temos que dar certo e dar lucro/ né/ então aí você junta/ soma dois e dois e vê se dá quatro

Para P4, as metas são claras e se tenta construir uma ponte entre estes dois objetivos, o aprimoramento pedagógico ("junto com o projeto do reflective") e o lucro garantido ("dar lucro"). É interessante que "dar certo" está ligado a "dar lucro", embora esse resultado ainda não está garantido ("soma dois e dois e vê se dá quatro", grifos nossos). Somar dois e dois aqui significaria tentar atingir os dois objetivos ao mesmo tempo. O projeto de ER torna-se outro, o "temos que dar certo", sendo que a palavra "temos", nesse enunciado, refere-se à instituição da qual P4 também faz parte, e não apenas aos professores.

Embora exista essa noção de estar trabalhando com objetivos distintos, o professor não só se engaja como demonstra preocupação com as metas e com a implementação de forças-tarefa que auxiliem a instituição.

\section{Excerto 18:}

P3: por causa dos números né/ SA [nome da filial] tá perdendo um monte de alunos/ eu acho acho ótimo ahh/ trabalhar no ciclo/ essa reflexão/ mas tem um a mais/ tem um pontinho a mais/ eu acho que o que a $\mathrm{G}$ [ele fala 0 nome da gerente] tá fazendo agora de a gente criar grupinhos de como podel resolverl esse problema tal/ eu acho que é além/ é muito além isso/ eu acho que/ (por exemplo) eu sei que é um given twenty students/ vinte alunos em sala de aula/ mas a gente sabe que não funciona/ nél é muito aluno em sala de aula/ principalmente no can-do/ né/ a nova assessment/ não tem como o observar um grande/ um mesmo/ a mesma situação você tem em numa aula/ então tem alguma coisa erradal eu acho que só o reflective não vai resolver 
P3 demonstra ser tudo que a escola quer de um professor. Em primeiro lugar, está preocupado em manter os alunos ("SA está perdendo um monte de alunos"). Depois, não só está de acordo com a criação de grupos de trabalho que apresentem soluções (" de a gente criar grupinhos de como pode/ resolver/ esse problema") como também demostra vontade de estar melhor preparado com o Ensino Reflexivo ("eu acho ótimo trabalhar no ciclo"). Ele só aparenta ir um pouco além do que a instituição gostaria quando critica a escola. P3 aponta falhas nos seus procedimentos, como a nova avaliação (" mas a gente sabe que não funciona/ né/ é muito aluno em sala de aula/...não tem como observar..."), mas aparenta conformidade com o número de alunos em sala de aula ("eu sei que é um given twenty students", grifos nossos) e, por fim, constata que "só o reflective não vai resolver". Ou seja, por mais que se proceda da maneira como a instituição deseja, o projeto não parece ser suficiente para que as metas sejam alcançadas. Mesmo assim, P3 procura maneiras de solucionar esses conflitos, o que faz que vá se adequando às posições de sujeito que ocupa.

As metas estabelecidas pela instituição são o tópico principal em várias discussões das reuniões, como também durante as entrevistas. Atingir a meta parece significar que o professor será reconhecido profissionalmente.

\section{Excerto 19:}

P3: my point is I'm your personal trainer/ you're paying me to be your personal trainerl and I decide you you need tol to fiftyl to do fifty push ups to do/ to get better trained

PM1: hum

P3: but you're not going to/ so what? you see the point?

P11: if you are giving the money and you don't see the point you

P3: that's what's happening in class

[P3 e P11 falam ao mesmo tempo, o argumento é que se a pessoa não tiver vontade ela não fará, mesmo se o personal trainer/ professor tiver certeza do que ela precisa fazer para melhorar]

P11:I know P3/ but you have to if you are my personal trainer/ and I pay you/ and I don't get/ I'm going to blame youl so you have to SHOW me the need to do that 
Vemos nesse excerto a importância de uma melhor relação custo-benefício para o aluno e o interesse de P3 na satisfação deste. O aprendiz é quem paga, portanto precisa ver resultados. O professor tem a obrigação de mostrar ("...SHOW me the need...") como o aluno, novamente generalizado, chegará a uma performance melhor se estudar, senão o efeito será o mesmo de alguém que contrata um personal trainer mas não faz os exercícios corretamente. O aluno precisa "see the point" para começar a colaborar em aula. Isso porque outro grande problema mencionado pelos professores tanto nas reuniões como nas entrevistas individuais é a dificuldade que o aluno tem de perceber que a aprendizagem não é um produto pronto a ser consumido. Por conseguinte, não basta apenas comprar o curso. Se o aprendiz não se envolve na aula ou tem alguma dificuldade para segui-la, ele não estará satisfeito, o que gera um conflito ainda maior.

P3 e P11, demonstram que a voz da QT fala mais alto. Eles usam do exemplo do aprendiz para mostrar a força que o cliente tem dentro da escola/ instituição. O "I" a que P11 se refere não é mais o "l" instituição que cobra os docentes, nem o "I" do professor que também presta um serviço. Ele é o "l" do cliente, e o professor, "you", tem que mostrar ao aluno a necessidade do aprendizado.

\section{Excerto 20:}

P8: we have to make them interested in the social act

P3: the point is/ before this/ this view we had to make their ends/ let's sayl make their ends meet with ours I mean/ you see the point? I NOW we are proposing something they don't want to do/ they don't want to go as slow as that/ they just want to communicatel they don't want to think if they are communicating the right wayl they want to MAKE it/ and that's all they want to do/ and if they are not proficient when they go to have a real social interaction in a firm/ or in a meeting/ real life when they can not ahh cope with in real life

P8: they will blame you

P3: our courl course is a flop according to that/ no matter what theory (...) you see the point?

Novamente as preocupações com o custo-benefício, as necessidades dos alunos e a comunicação como meta principal dos aprendizes ficam visíveis. O "social act" 
implicaria não só a língua como a atitude ao usá-la, por exemplo, se alguém fosse pedir uma comida em um restaurante necessitaria das palavras e da maneira correta de pedir, senão seria visto como uma pessoa mal-educada. A professora aponta para a necessidade de satisfação imediata dos desejos dos clientes ("...they want to MAKE it/...") em contraposição a um acordo entre as necessidades das duas partes (o professor com seu plano de aula e o aluno com a necessidade de comunicação). A fala de P3 revela também que, ao não ir ao encontro das necessidades dos clientes o curso "is a flop", ou seja, um desastre. O curso já não faz parte apenas da grade da escola, torna-se seu ("...our course..."), o que dá a entender que o insucesso do curso é para essa professora um fracasso pessoal.

O professor, dessa forma, age de acordo com o pensamento da QT, procurando estar sempre pronto a solucionar problemas, razão pela qual ele é a autoridade em sala de aula ("make their ends meet with ours"). Ele procura destacar o aspecto pedagógico do ER, ao querer ser visto como docente e não como prestador de serviços, como vimos no excerto 14 em que a professora diz que "hoje em dia você não tem mais alunos...a gente acaba esquecendo que está numa escola, então estranha um pouquinho". Entretanto, sua fala é permeada por idéias provenientes da Qualidade Total, como a qualidade enquanto estratégia competitiva (mais qualidade, mais alunos) e a qualidade-produtividade-rentabilidade (a qualidade é boa quando produz resultados), além das noções de satisfação do cliente. Aparentemente, o discurso educacional e o da QT são distintos, mas, assim como acontece com as formações discursivas, na realidade seus limites não são definidos, o que causa as contradições nos enunciados dos professores. Essas contradições fazem parte dos processos de identificação temporários pelos quais os sujeitos passam, no caso, os professores.

\section{Conclusão}

Através dos excertos selecionados, procuramos demonstrar que compartilhamos a visão pós-moderna de identidade, a qual postula que nossas identidades estão pluralizadas no universo discursivo. Essa pluralização se dá de diversas maneiras, 
pela ideologia que afeta o sujeito, pela dispersão do discurso (que também é constituído pelo discurso do interlocutor, do "outro"), ou mesmo pelas formas de manifestação da heterogeneidade conforme Authier-Revuz (1982).

Ao focalizar os enunciados dos professores, podemos concluir que sua fala é cindida, heterogênea e influenciada pelas vozes dos outros, o que produz uma série de contradições em seu discurso. Esses conflitos ocorrem porque o discurso dos professores, PMs e gerentes também é constituído, não só pelo discurso educacional (aqui ressaltado pelo ER), mas pelo discurso neoliberal de QT, entre outros. Essas vozes estão em constante diálogo e aparecem no decorrer dos depoimentos.

O corpo docente se vê em posições conflitantes, dividido entre o que é ser um professor ideal sob a perspectiva da escola/ instituição (baseada em itens de controle quantitativos) e sob sua própria perspectiva de ensino (que pressupõe, em teoria, a aprendizagem qualitativa). O professor procura enfatizar o crescimento pedagógico a partir do projeto, tentando não demonstrar resistência para que seu futuro profissional não seja colocado em risco.

Ao mesmo tempo, a fala dos professores revela que eles estão constituídos pelo discurso institucional e que se preocupam em cumprir as metas e tentar chegar à satisfação total do cliente com as aulas. Apesar de não aceitar o sentido quantitativo do discurso da QT, o docente assume a culpa pelo insucesso das aulas e acaba por remeter-se à própria QT para tentar argumentar a seu favor. Assim, ele procura descobrir falhas em suas atitudes em sala de aula e resolvê-las, preocupa-se com a satisfação do cliente e tenta ir além de suas funções para que o aluno volte à escola.

Enfim, diante da estrutura do ER proposto pela instituição, o professor mostra que é um sujeito dividido, multi-facetado. Contudo, mesmo não tendo autonomia sobre os fins e técnicas propostos pelo projeto, e sendo visto como um técnico que deve saber como chegar aos níveis de eficiência propostos pelo instituto de línguas, o 
professor produz saber, pois organiza-se de maneira a lidar com sua realidade profissional. Ele parece lidar, mesmo que inconscientemente, com a ordem do discurso (Foucault, 1971/1999), e acaba por tentar moldar sua fala em relação ao outro para assegurar sua posição. Os antagonismos que enfrenta também fazem parte de seu discurso, o que faz com que sua identidade esteja em constante mudança. 


\section{CONSIDERAÇÕES FINAIS}

$\mathrm{Na}$ introdução desta dissertação, apresentamos o percurso desenvolvido até que chegássemos ao tema proposto, aos questionamentos básicos e à escolha do tipo de análise a ser empreendida.

Partindo da hipótese de que o discurso neoliberal de Qualidade Total constitui o discurso educacional do programa de treinamento em serviço de um instituto de línguas, funcionando como um mecanismo de controle, conforme proposto por Foucault (1971/1999; 1987/2000; 1979/2000; 2000; 1988/2001), procuramos realizar uma análise dos discursos de professores e gerentes de um instituto de ensino de língua estrangeira. Para tanto, focalizamos sua ligação com o discurso neoliberal de Qualidade Total, o controle do discurso e a heterogeneidade das identidades dos sujeitos envolvidos.

A implantação do programa de Ensino Reflexivo contou com uma organização peculiar em que não apenas a formação do docente estava em jogo, mas toda uma instituição de ensino. Isto porque o Ensino Reflexivo tinha, a princípio, sido apresentado de acordo com a proposta de Richards \& Lockhart (1994) que visava à formação do professor como agente de seu conhecimento. Porém, como pudemos constatar no decorrer desta dissertação, o projeto esteve baseado nos princípios neoliberais da Qualidade Total, o que significou uma drástica mudança no tipo de resultado esperado pela instituição.

Primeiramente, o projeto foi apresentado de forma sutil e não-obrigatória, a partir da qual os docentes eram convidados a fazer parte do que seria uma inovação em termos educacionais. Devido ao tamanho da instituição, foram criados papéis a serem desempenhados por professores escolhidos, os professores-multiplicadores, para que as noções referentes ao Ensino Reflexivo fossem multiplicadas e, conseqüentemente, melhor aceitas pelo grupo. Assim, os professores eram introduzidos a idéias para aprimorar sua prática pedagógica e torná-los mais 
conscientes de seu papel de educadores. Ao mesmo tempo, gerentes e funcionários eram treinados conforme os pressupostos da gerência de qualidade, a qual tinha como meta primordial a satisfação dos clientes.

Posteriormente, outros pressupostos do discurso de Qualidade Total passaram a ter destaque nos momentos de reflexão dos docentes. As reuniões sobre o projeto se tornariam, então, espaço para as discussões sobre como a escola e os professores deveriam se esforçar para atingir as metas de satisfação de seus cursos. Ou seja, houve um deslocamento do objetivo do projeto, que culminou com as reuniões sendo usadas para discussões a respeito de técnicas de ensino, como constatamos em nossa análise. O novo modelo de aula baseado no Ciclo de Aprendizagem Experimental parecia ser também o responsável por algumas dificuldades enfrentadas pelos sujeitos envolvidos no projeto, bem como pela filial da instituição estudada. Entre essas dificuldades estava a confusão dos professores em relação ao seu plano de aula e a diminuição do número de alunos, tão ressaltada pela escola.

Parker (1997) ressalta que o Ensino Reflexivo, como fora concebido por seus autores, tentou romper com o positivismo e o racionalismo técnico, os quais viam o professor como transmissor de técnicas, sendo, assim, incapaz de tomar uma posição de agente. Conforme a postura positivista, o professor-técnico devia saber como chegar a determinados níveis de eficiência que seriam comprovados por fatos. A generalização desses fatos levaria à conquista dos resultados, o que se assemelha à visão neoliberal da Qualidade Total.

Contudo, se por um lado o Ensino Reflexivo envolve muito mais que a racionalização do ato de ensinar, por outro ainda há o medo de que ele seja uma maneira de aceitar o pluralismo. Os professores reflexivos deveriam ser diferentes à medida que estivessem conscientes das complicações sociais da prática e da política educacionais. Assim, a ênfase não estaria mais voltada ao treinamento, mas sim à educação do professor como agente social. 
Em nosso contexto, fica claro que a instituição educacional, ao menos no momento estudado, não privilegiava a perspectiva do docente como agente. As "reuniões de ER" que são parte de nosso corpus funcionavam como mecanismo de controle do discurso e do saber. O conhecimento a ser construído estava previamente planejado pela instituição, e o espaço para a discussão de temas pertinentes (conforme a ótica dos docentes) era reduzido. Além disso, existia a constante vigilância da gerência, através da sua participação nas reuniões ou de outros itens de controle, como os planos de ação semestrais, as observações de aula (e as discussões posteriores), ou mesmo os questionários de satisfação dos alunos.

Com efeito, o controle exercido pela instituição e o uso de métodos quantitativos de medição de eficiência fazem parte da influência do discurso neoliberal de Qualidade Total. Com o passar do tempo, não só esse discurso ficou visível na estrutura do projeto, como passou a constituir o discurso dos professores. Cada vez mais o espaço nas reuniões era devotado à discussão de assuntos relacionados à satisfação dos alunos/ clientes e à importância da aula com qualidade para que o projeto "desse certo".

O programa de treinamento de Ensino Reflexivo no instituto de línguas passou a ser visto como um meio de alcançar metas necessárias para o crescimento da escola como empresa. Estávamos diante de um objetivo bem diferente daquele que fora proposto no início, que era o estabelecimento de uma atmosfera baseada na confiança mútua, cooperação e aceitação de diferenças na qual o questionamento e a reflexão constantes provocariam a curiosidade do docente acerca de sua prática e de sua relação com o aluno.

Face a essa constatação, e considerando-se a visão pós-moderna de identidade, a heterogeneidade dos sujeitos envolvidos em nossa pesquisa necessitava ser discutida. Acompanhando os pressupostos da Análise do Discurso, partimos de uma visão de sujeito situado no contexto histórico-político-social que é perpassado pela 
ideologia, o que torna esse sujeito multi-facetado sem que necessariamente ele esteja consciente disso (Carmagnani, 1996). O discurso do professor é atravessado por outros discursos, e o seu relacionamento com o outro o ajuda a se reconhecer como sujeito. Assim, dependendo do interlocutor, o professor tenta adequar a sua fala. Para isto, ele apropria-se das palavras dos outros para ser aceito e busca participar do discurso que é autorizado pela instituição, ao mesmo tempo que resiste a ele.

O professor focalizado em nosso trabalho demonstra estar dividido entre a sua missão de educador e sua posição de prestador de serviço, assim como o projeto de Ensino Reflexivo oscila entre as características qualitativas (relacionadas à reflexão) e as quantitativas (as estatísticas a respeito do desempenho da escola). Isto não quer dizer que estejamos diante de uma dicotomia, do lado "certo" e do "errado", pois a separação entre esses discursos não é clara ou objetiva. Assim como as formações discursivas regulam o que pode ou deve ser dito dependendo de seus limites e das formações ideológicas (Pêcheux, 1975) a que estão ligadas, os sentidos são modificados dependendo das condições de produção do discurso. Os docentes do projeto compartilham de regras legitimadas de comunicação dentro do instituto de línguas e a sua fala transita dentro desses limites, de acordo com suas necessidades, sem que haja necessariamente consciência disso.

Desse modo, não pretendemos avaliar se a influência do discurso neoliberal de Qualidade Total é boa ou má para o projeto e o professor da instituição focal, mas apontar de que maneira esse e outros discursos constituem não apenas o programa de treinamento citado, mas outras situações vivenciadas pelo professor. Em outras palavras, não podemos afirmar se a proposta de Ensino Reflexivo, conforme foi implementada, poderia ter sido melhor caso o discurso de Qualidade Total não a constituísse. Mesmo porque isso não seria possível em nossas condições sóciohistóricas. Entendemos, outrossim, que o projeto funcionou como um mecanismo de controle, regulando a produção de sentidos e os poderes constituídos, produzindo 
uma série de efeitos que foram vivenciados pelos sujeitos desta pesquisa na instituição focalizada.

Ao mesmo tempo, compartilhamos do pensamento de Foucault (1979/2000) que postula que o poder não é apenas repressivo, pois também gera saber. O saber gerado pelo projeto situa-se nas reuniões de ER, nas conversas informais dos professores, nos silêncios analisados e, acima de tudo, nos efeitos causados por esses discursos na instituição. Da mesma maneira que os objetivos foram mudados no decorrer do projeto visando a uma adequação às necessidades do instituto de línguas, o corpo docente também mudou. De fato, no momento da finalização desta dissertação, quase a metade do número de professores é constituída de profissionais que sequer viram o desenrolar do projeto. Tanto que, no momento atual, o treinamento em serviço voltou a ter como objetivo a capacitação dos professores para atuar de acordo com técnicas de ensino que promovam o aprendizado de habilidades lingüísticas (a leitura, a escrita, a compreensão oral e a conversação).

Partindo das reflexões apresentadas ao longo desta dissertação, verificamos que o discurso do programa de treinamento em serviço da instituição focal é constituído pelo discurso neoliberal de Qualidade Total e funciona como um mecanismo de controle. Esperamos que esta análise possa contribuir para a compreensão das relações estabelecidas nos programas de treinamento no contexto da escola e dos processos de constituição dos sujeitos envolvidos, servindo de subsídio para pesquisas nas áreas de formação de professores e de ensino-aprendizagem de línguas estrangeiras. 


\section{REFERÊNCI AS BI BLI OGRÁFI CAS}

AMARANTE, M.F.S. Ideologia Neoliberal no Discurso da Avaliação: A Excelência e o Avesso da Excelência. Tese de Doutorado. UNICAMP, Campinas. 1998.

ALTHUSSER, L. Ideologia e Aparelhos Ideológicos do Estado. São Paulo: Graal. 1918/1998.

AUTHIER-REVUZ, J. Hétérogénéité Montrée et Hétérogénéité Constitutive: Éléments pour une Approche de L'Autre dans le Discours. In: DRLAV, 26. Paris: Centre de Recherches de L'Université de Paris VII. 1982.

AUTHIER-REVUZ, J. Palavras Incertas: as Não-coincidências do Dizer Campinas, SP: Editora da Unicamp. 1998.

BAKHTIN, M. Estética da Criação Verbal. São Paulo: Martins Fontes. 1992.

BAKHTIN, M. Marxismo e Filosofia da Linguagem. São Paulo: Hucitec. 1992a.

BRANDÃO, H. Introdução à Análise do Discurso. Campinas: Editora da Unicamp. 1991.

BROWN, H.D. Principles of Language Learning and Teaching. Englewood Cliffs: Prentice Hall Regents. 1993.

BROWN, H.D. Teaching by Principles: An Interactive Approach to Language Teaching. Englewood Cliffs: Prentice Hall Regents. 1994. 
CARMAGNANI, A.M.G. A Argumentação e o Discurso Jornalístico: a Questão da Heterogeneidade em Jornais Ingleses e Brasileiros. Tese de Doutorado. PUC-SP, São Paulo. 1996.

CARMAGNANI, A.M.G. As Escolas de Línguas e o Discurso Publicitário: Construindo o Desejo da Língua Estrangeira. In: CARMAGNANI, A.M.G.; GRIGOLETTO, M. (orgs.) Inglês Como Língua Estrangeira: Identidade, Práticas e Textualidade. São Paulo: Humanitas/ FFLCH/USP. 2001.

CARMAGNANI, A.M.G.; GRIGOLETTO, M. (orgs.) Inglês Como Língua Estrangeira: Identidade, Práticas e Textualidade. São Paulo: Humanitas/ FFLCH/USP. 2001.

CORACINI, M.J.R.F. A Escamoteação da Heterogeneidade nos Discursos da Lingüística Aplicada e da Sala de Aula. In: Letras- Revista do Mestrado em Letras da UFSM (RS). Janeiro/ Junho. 1997.

DEMING, W.E. Qualidade: A Revolução na Administração. Rio de Janeiro: Ed. Marques Saraiva. 1990. In: GENTILI, P.A.; SILVA, T.T. Neoliberalismo, Qualidade Total e Educação. Petrópolis: Vozes. 2001.

DUCROT, O. O Dizer e o Dito. Campinas: Pontes. 1987.

FOUCAULT, M. A Ordem do Discurso. São Paulo: Edições Loyola. 1971/1999.

FOUCAULT, M. Microfísica do Poder. Rio de Janeiro: Graal. 1979/2000.

FOUCAULT, M. Vigiar e Punir. Petrópolis: Vozes. 1987/2000.

FOUCAULT, M. A Arqueologia do Saber. São Paulo: Editora Forense Universitária. 2000. 
FOUCAULT, M. História da Sexualidade 1: A Vontade de Saber. Rio de Janeiro: Graal. 1988/2001.

FOUCAULT, M. Tecnologies of The Self . In: MARTIN, L.H. et al Technologies of the Self: a Seminar with Michel Foucault. London: Tavistock. 1988. Disponível em : <http://www.thefoucauldian.co.uk>. Acesso em: out. 2002.

FREIRE, P. Pedagogia da Autonomia. São Paulo: Paz e Terra. 1997.

GADGET, F. \& HAK, T. (orgs.) Por uma Análise Automática do Discurso. Campinas: Editora da Unicamp. 1997.

GENTILI, P.A. O Discurso da Qualidade Como Nova Retórica Conservadora no Campo Educacional. In: GENTILI, P.A.; SILVA, T.T. Neoliberalismo, Qualidade Total e Educação. Petrópolis: Vozes. 2001.

GENTILI, P.A.; SILVA,T.T. Neoliberalismo, Qualidade Total e Educação. Petrópolis: Vozes. 2001.

GRADDOL, D.; MAYBIN, J. STIERER, B. (ed) Researching Language and Literacy in Social Context. London: Multilingual Matters. 1994.

GLASSER, M. The Quality School. Managing students without coercion. Harper Collins Publishers. In: GENTILI, P.A.; SILVA, T.T. Neoliberalismo, Qualidade Total e Educação. Petrópolis: Vozes. 2001.

GRIGOletTO, M. A Resistência das Palavras. Campinas: Editora da Unicamp. 2002.

HALL, S. A Identidade Cultural na Pós-modernidade. Rio de Janeiro: DP\&A. 2000. 
HAMMERSLEY, M. ATKINSON, P. Ethnography: Principles in Practice. London : Tavistock Publications. 1983.

HAMMERSLEY, M. Introducing Ethnography. In: Graddol, D. Maybin, J. Stierer, B. (ed) Researching Language and Literacy in Social Context. London: Multilingual Matters. 1994.

HORNBERGER, N. Etnography. In: Alternatives in TESOL Research: Descriptive, Interpretive, and Ideological Orientations. Tesol Quarterly Vol. 28, №4. 1994.

INDURSKY, F. O Sujeito e As Feridas Narcísicas dos Lingüistas. Revista Gragoatá. $2^{\circ}$ semestre de 1998 . Niterói, RJ.

INFANTE, S. Diversidade e Alteridade na Enunciação em Línguas Próximas. In: Letras- Revista do Mestrado em Letras da UFSM (RS). Janeiro/ Junho. 1997.

KOLB, D. Experiential Learning. Englewood Cliffs: Prentice-Hall, Inc. 1984.

LACLAU, E. New Reflections on the Resolution of our Time.Londres: Verso, 1990. In: HALL, S. A identidade Cultural na Pós-modernidade. Rio de Janeiro: DP\&A. 2000.

LIGHTBOWN, P.; SPADA, N. How Languages Are Learned. Oxford: Oxford University Press. 1993.

MAINGUENEAU, D. Novas Tendências em Análise do Discurso. Campinas: Pontes/ Editora da Unicamp. 1997.

MAINGUENEAU, D. Análise de Textos de Comunicação. São Paulo: Cortez Editora. 2002. 
MARCELLO, N.M.R.F. Uma Análise Discursiva de Aulas de Língua Estrangeira no Contexto de Empresas. Dissertação de Mestrado. USP, São Paulo. 2000.

MARTIN, L.H. et al Technologies of the Self: a Seminar with Michel Foucault. London: $\quad$ Tavistock. $1988 . \quad$ Disponível em: <http://www.thefoucauldian.co.ukwww.aaa.com>. Acesso em: out. 2002.

ORLANDI, E. Análise de Discurso: Princípios e Procedimentos. Campinas: Pontes. 1999.

ORLANDI, E. As Formas do Silêncio: no Movimento dos Sentidos. Campinas: Editora da Unicamp. 1997.

PARKER, S. Reflective Teaching in the Postmodern World: a Manifesto for Education in Postmodernity. Buckingham: Open University Press. 1997.

PÊCHEUX, M. Análise Automática do Discurso. 1969. In: GADGET, F. \& HAK, T. (orgs.) Por uma Análise Automática do Discurso. Campinas: Editora da Unicamp. 1997.

PÊCHEUX, M. A Propósito da Análise Automática do Discurso: Atualização e Perspectivas. 1975. In: GADGET, F. \& HAK, T. (orgs.) Por uma Análise Automática do Discurso. Campinas: Editora da Unicamp. 1997.

PÊCHEUX, M. O Discurso: Estrutura ou Acontecimento. Campinas: Pontes. 1997.

PENNYCOOK, A. English and the Discourses of Colonialism. London: Routledge. 1998. 
RAMOS, C. Excelência na Educação. A Escola de Qualidade Total. Rio de Janeiro: Qualitymark, 1992. In: GENTILI, P.A.; SILVA, T.T. Neoliberalismo, Qualidade Total e Educação. Petrópolis: Vozes. 2001.

RICHARDS, J. \& LOCKHART, C. Reflective Teaching in Language Classrooms . New York: Cambridge University Press. 1994.

SCARCELLA, R. ; OXFORD, R. The Tapestry of Language Learning: The Individual in the Communicative Classroom. Boston: Heinle \& Heinle Publishers. 1992.

SILVA, T.T. A Nova direita e as Transformações na Pedagogia da Política e na Política da Pedagogia. In: GENTILI, P.A.; SILVA,T.T. Neoliberalismo, Qualidade Total e Educação. Petrópolis: Vozes. 2001.

SCRIVENER, J. Learning Teaching. Oxford: Heinmann. 1994.

SWANN, J. Observing and Recording Talk in Educational Settings. In: GRADDOL, D.; MAYBIN, J. STIERER, B. (ed) Researching Language and Literacy in Social Context. London: Multilingual Matters. 1994.

TAGATA, W. Reflective Teaching na Formação do Professor de Língua Estrangeira: Análise de uma Experiência. Dissertação de Mestrado. USP, São Paulo. 2000.

VAN LIER, L. The Classroom and the Language Learner: Ethnography and Second Language Research. London: Longman. 1988.

WATSON-GEGEO, K. Ethnography in ESL: Defining the Essentials. 1988. In: Tesol Quarterly, vol. 22, No. 4. 